\title{
Environmental Protection Department Operations and Regulatory Affairs Division \\ LLNL NESHAPs 2000 Annual Report
}

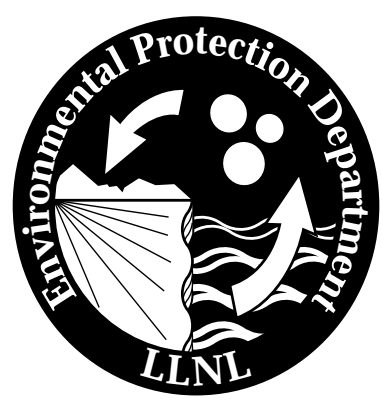

Lawrence Livermore National Laboratory University of California Livermore, California 94551 


\section{DISCLAIMER}

This document was prepared as an account of work sponsored by an agency of the United States Government. Neither the United States Government nor the University of California nor any of their employees, makes any warranty, express or implied, or assumes any legal liability or responsibility for the accuracy, completeness, or usefulness of any information, apparatus, product, or process disclosed, or represents that its use would not infringe privately owned rights. Reference herein to any specific commercial product, process, or service by trade name, trademark, manufacturer, or otherwise, does not necessarily constitute or imply its endorsement, recommendation, or favoring by the United States Government or the University of California. The views and opinions of authors expressed herein do not necessarily state or reflect those of the United States Government or the University of California, and shall not be used for advertising or product endorsement purposes.

This work was performed under the auspices of the U. S. Department of Energy by the University of California, Lawrence Livermore National Laboratory under Contract No. W-7405-Eng-48.

This report has been reproduced directly from the best available copy.

Available electronically at http://www.doc.gov/bridge

Available for a processing fee to U.S. Department of Energy

And its contractors in paper from

U.S. Department of Energy

Office of Scientific and Technical Information

P.O. Box 62

Oak Ridge, TN 37831-0062

Telephone: (865) 576-8401

Facsimile: (865) 576-5728

E-mail: reports@adonis.osti.gov

Available for the sale to the public from

U.S. Department of Commerce

National Technical Information Service

5285 Port Royal Road

Springfield, VA 22161

Telephone: (800) 553-6847

Facsimile: (703) 605-6900

E-mail: orders@ntis.fedworld.gov

Online ordering: http://www.ntis.gov/ordering.htm

OR

Lawrence Livermore National Laboratory

Technical Information Department's Digital Library

http:/ / www.llnl.gov/tid/Library.html 


\section{LLNL NESHAPs 2000Annual Report}

Gretchen M. Gallegos Robert J. Harrach Robert L. Berger Nicholas A. Bertoldo Paula J. Tate Sylvie-Ring Peterson

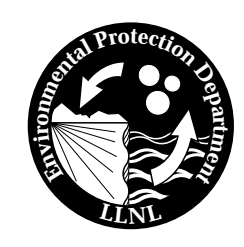

Contributors:

Frank J. Gouveia Paris E. Althouse Judy L. Kelly 



\section{U.S. Department of Energy \\ Radionuclide Air Emission Annual Report \\ (under Subpart H of 40 CFR Part 61) \\ Calendar Year 2000}

Site Name: $\quad$ Lawrence Livermore National Laboratory

\section{Operations Office Information}

Office: $\quad$ U.S. Department of Energy

Oakland Office

Address: $\quad 1301$ Clay Street, Rm 700N

Oakland, CA 94612-5208

Contact: $\quad$ Steve Black

Phone: 510-637-1595

\section{$\underline{\text { Site Information }}$}

Operator: $\quad$ University of California

Address: $\quad 7000$ East Avenue

Livermore, CA 94551

Contact: C. Susi Jackson Phone: 925-423-6577 
LLNL NESHAPs Report 2000 


\section{Table of Contents}

SYNOPSIS

SECTION I. Facilities Information ................................................................................2

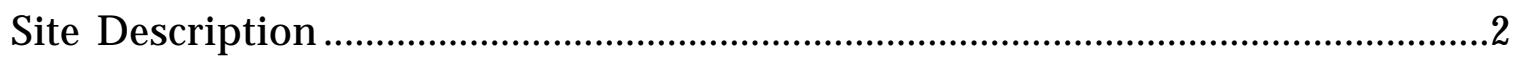

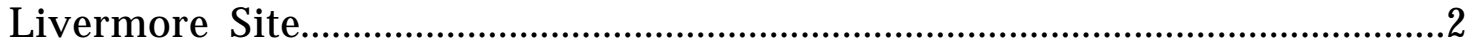

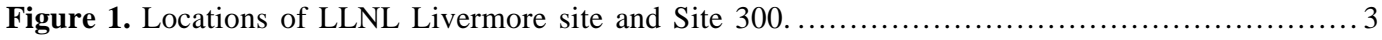

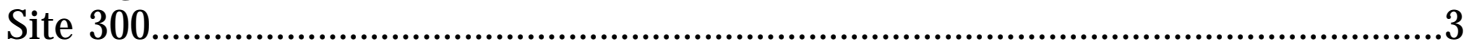

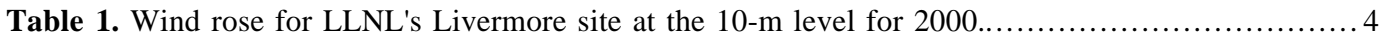

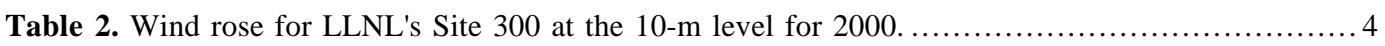

Figure 2. Wind rose showing the average annual wind speed, frequency of occurrence, and direction at

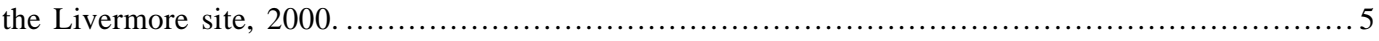

Figure 3. Wind rose showing the average annual wind speed, frequency of occurrence, and direction at

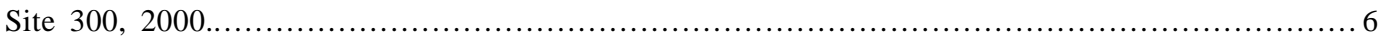

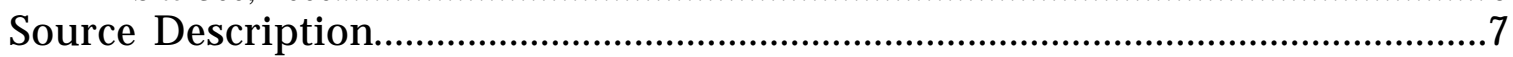

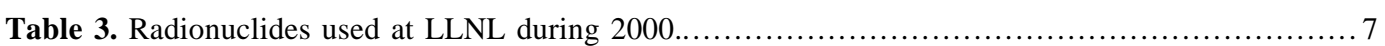

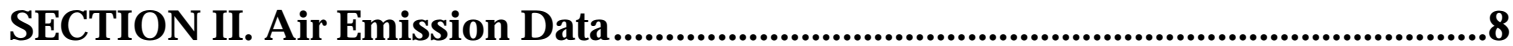

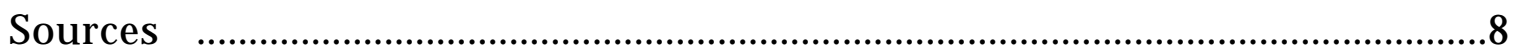

2000 Radionuclide Usage Inventory Update and Effective Dose Equivalent

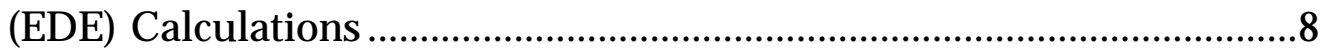

Tritium Monitoring and Dose Assessment.......................................................

Figure 4. Combined HT and HTO emissions from the Tritium Facility, 1981-2000.............. 10

Gross Alpha and Gross Beta Monitoring and Dose Assessment.....................12

SECTION III. Dose Assessment..........................................................................14

Description of the Air Dispersion and Dose Model ...............................................14

Summary of Model Input Parameters ....................................................................14

General Model Inputs................................................................................14

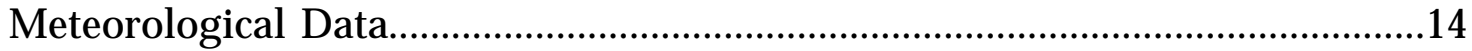

Surrogate Radionuclides...................................................................................15

Population Inputs.............................................................................................15

Land Use and Agricultural Inputs ..................................................................15

Emission Source Terms............................................................................15

Table 4. List of materials for which exemption from the required assumption that any material heated above $100^{\circ} \mathrm{C}$ is a gas and temperatures at which the physical state factors apply..................... 16

Site-Wide Maximally Exposed Individual.........................................................17

Figure 5. Location of Site-Wide Maximally Exposed Individual (SW-MEI) at the Livermore site,

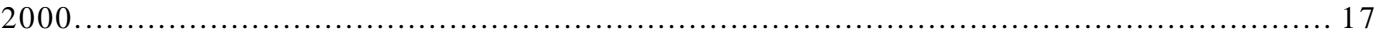


Maximally Exposed Public Individual .....................................................18

Figure 6. Location of Site-Wide Maximally Exposed Individual (SW-MEI) at Site 300, 2000....... 19

Special Modeling Challenges ..................................................................19

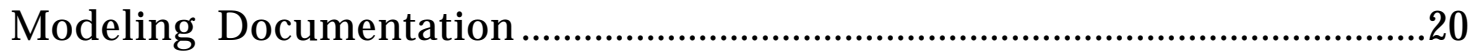

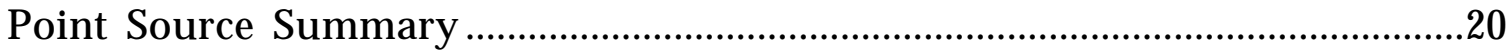

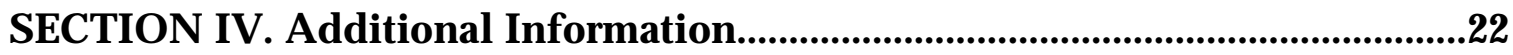

Construction and Modifications.....................................................................22

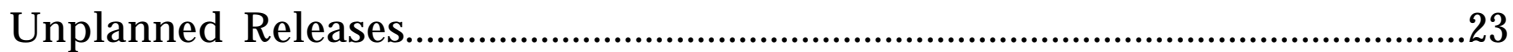

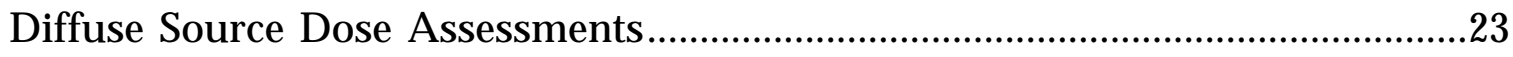

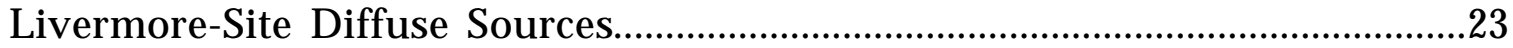

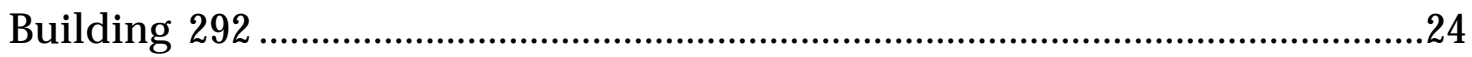

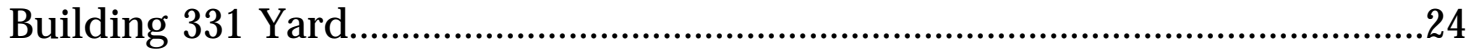

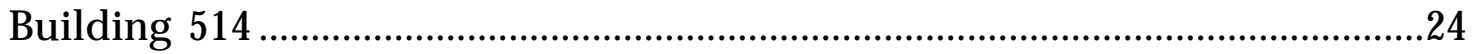

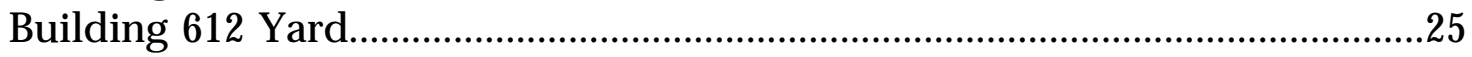

Waste Accumulation Area Drum Sampling.....................................................25

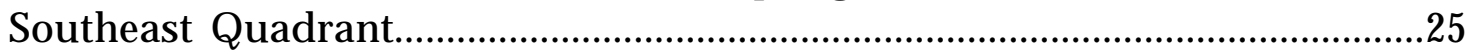

Building 223 Soil and Gravel Cleanup..............................................................26

Site 300 Diffuse Sources.......................................................................................26

Tritium Evaporation and Migration at Site 300...............................................26

Resuspension of Depleted Uranium at Site 300..............................................27

Total Dose Estimate and Comparison with Previous Years' Data ......................28

Table 5. List of facilities or sources whose emissions account for $90 \%$ or more of the doses for the

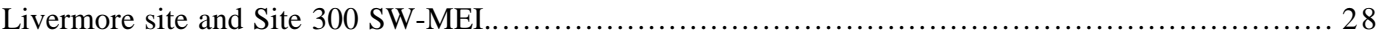

Table 6. Doses (in mrem) calculated for the Site-Wide Maximally Exposed Individual for the Livermore

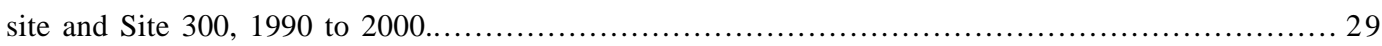

SECTION V. Certification .................................................................................................30

SECTION VI. Supplemental Information....................................................................31

Collective Effective Dose Equivalent....................................................................31

Table 7. Population distribution for LLNL's Livermore site, based on LandScan Global Population

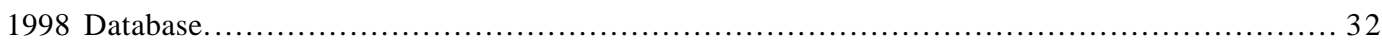

Table 8. Population distribution for LLNL's Site 300, based on LandScan Global Population 1998

Database. .............................................................................. 32

Compliance with 40 CFR 61 Subpart H (61.93) .......................................................33

Status of compliance with 40 CFR 61 Subpart Q -

National Emission Standards for Radon Emissions from

Department of Energy Facilities.

Status of compliance with 40 CFR 61 Subpart T -

National Emission Standards for Radon Emissions from the

Disposal of Uranium Mill Tailings. 


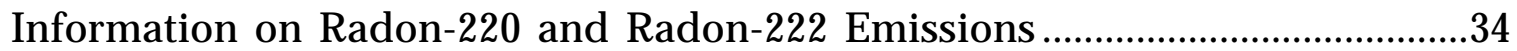

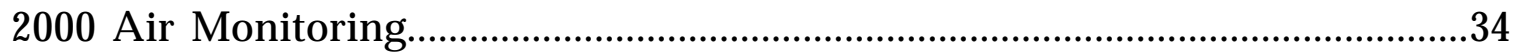

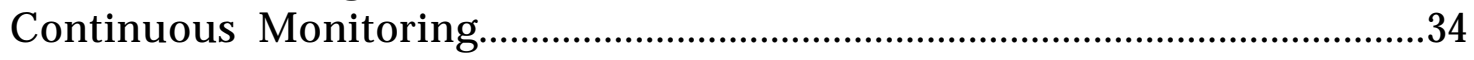

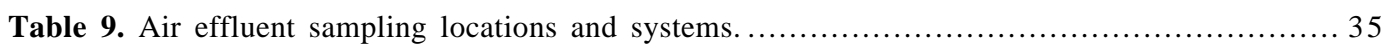

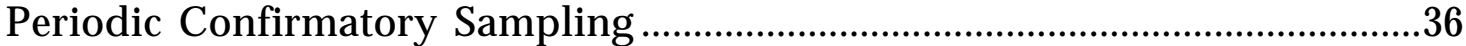

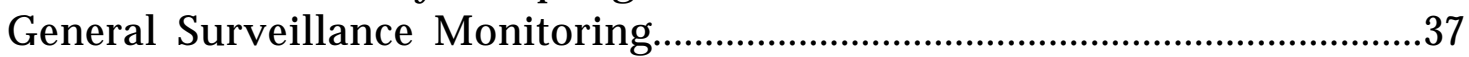

Comparison of 2000 Modeling Results with Surveillance Monitoring Data...37

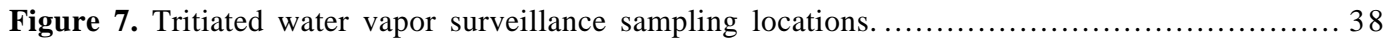

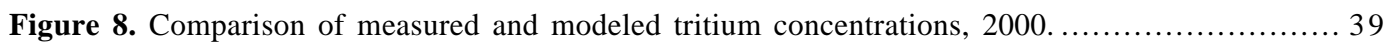

The NESHAPs QA Program................................................................................

Quality Control (QC) for 2000 Radiological Usage Inventory Update and Modeling........................................................................................................41

Radiological Usage Inventory and Modeling QC ...............................................41

EPA Compliance Evaluation Investigation............................................................42

Attachment 1. LLNL NESHAPs 2000 Annual Report Spreadsheet.....................43

Guidance for Interpreting Attachment 1.................................................................43

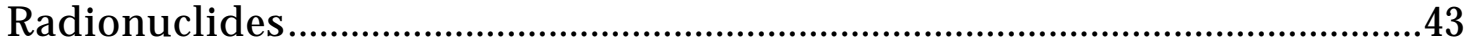

Radionuclide Usage Inventories with Potential for Release ............................43

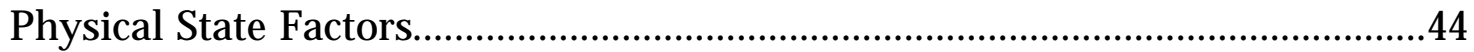

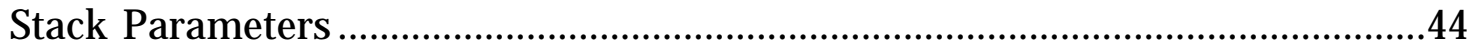

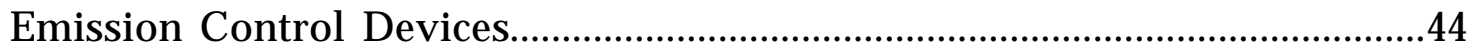

Control Device Abatement Factors .....................................................................4

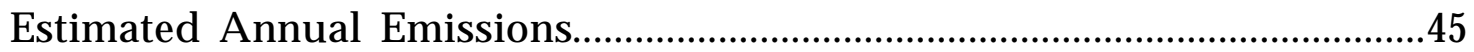

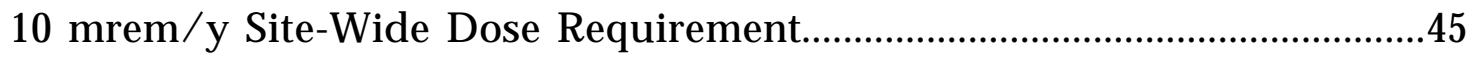

$0.1 \mathrm{mrem} / \mathrm{y}$ Monitoring Requirement...........................................................45

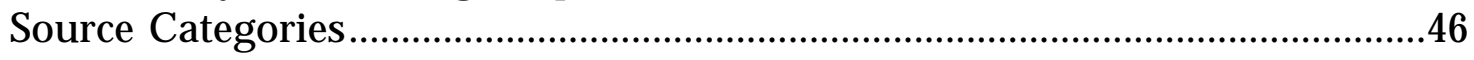

Attachment 2. Brief Survey of the NEWTRIT Model.............................................67

Attachment 3. Surrogate Radionuclides List..............................................................69

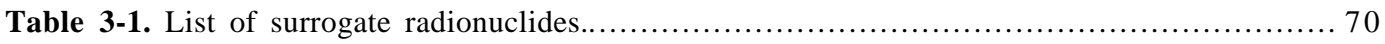




\section{Lawrence Livermore National Laboratory NESHAPs 2000 Annual Report}

This annual report is prepared pursuant to the National Emissions Standards for Hazardous Air Pollutants (NESHAPs) 40 CFR Part 61, Subpart H; Subpart H governs radionuclide emissions to air from Department of Energy (DOE) facilities.

\section{SYNOPSIS}

NESHAPs limits the emission of radionuclides to the ambient air from DOE facilities to levels resulting in an annual effective dose equivalent (EDE) of 10 mrem $(100 \mu \mathrm{Sv})$ to any member of the public. The EDEs for the Lawrence Livermore National Laboratory (LLNL) site-wide maximally exposed members of the public from 2000 operations are summarized here.

- $\quad$ Livermore site: $0.038 \mathrm{mrem}(0.38 \mu \mathrm{Sv})$ (45\% from point-source emissions, $55 \%$ from diffuse-source emissions). The point-source emissions include gaseous tritium modeled as tritiated water vapor as directed by EPA Region IX, and the resulting dose is used for compliance purposes.

- $\quad$ Site 300: 0.019 mrem (0.19 $\mu \mathrm{Sv})$ (79\% from point-source emissions, $21 \%$ from diffuse-source emissions).

The EDEs were calculated using the EPA-approved CAP88-PC air dispersion/dose-assessment model, except for doses for four diffuse sources, which were calculated from measured concentrations and dose coefficients. Site specific meteorological data, stack flow data, and emissions estimates based on radionuclide usage inventory data or continuous stack monitoring data were the specific input to CAP88-PC for each modeled source. 


\section{SECTION I. Facilities Information}

\section{Site Description}

LLNL was established in 1952 to conduct nuclear weapons research and development. The Laboratory's mission is dynamic and has been broadened over the years to meet new national needs. LLNL serves as a national resource in science and engineering; its activities focus on global security, energy, global ecology, biomedicine, economic competitiveness, and science and mathematics education. LLNL consists of two sites-the main laboratory site located in Livermore, California (Livermore site), and the Experimental Test Facility (Site 300) located near Tracy, California. Figure 1 shows the locations of the sites. The University of California operates LLNL for DOE.

\section{Livermore Site}

LLNL's Livermore site occupies an area of $3.3 \mathrm{~km}^{2}$ located about $60 \mathrm{~km}$ east of San Francisco, California, adjacent to the City of Livermore in the eastern part of Alameda County. In round numbers, 7 million people live within $80 \mathrm{~km}$ of the Livermore site; 73,600 of them live in the City of Livermore.

The Livermore site is located in the southeastern portion of the Livermore Valley, a topographical and structural depression oriented east-west within the Diablo Range of the California Coast Range Province. The Livermore Valley forms an irregularly shaped lowland area approximately $26 \mathrm{~km}$ long and an average of $11 \mathrm{~km}$ wide. The floor of the valley slopes from an elevation of approximately $200 \mathrm{~m}$ above sea level at the eastern end to approximately $90 \mathrm{~m}$ above sea level at the southwest corner.

The climate of the Livermore Valley is characterized by mild, rainy winters and warm, dry summers. The mean annual temperature is about $15^{\circ} \mathrm{C}$. Temperatures typically range from $-5^{\circ} \mathrm{C}$ during some pre-dawn hours in the winter, to $40^{\circ} \mathrm{C}$ on a few summer afternoons. The 2000 annual wind data for the Livermore site are shown in Table 1 and displayed as a wind rose in Figure 2. Although winds are variable, the prevailing wind direction is from the southwest, especially during the summer. However, during the winter, the wind often blows from the northeast. Most precipitation occurs as rain between October and April with very little rainfall during the summer months. In 2000, the Livermore site received $295 \mathrm{~mm}$ of precipitation. 


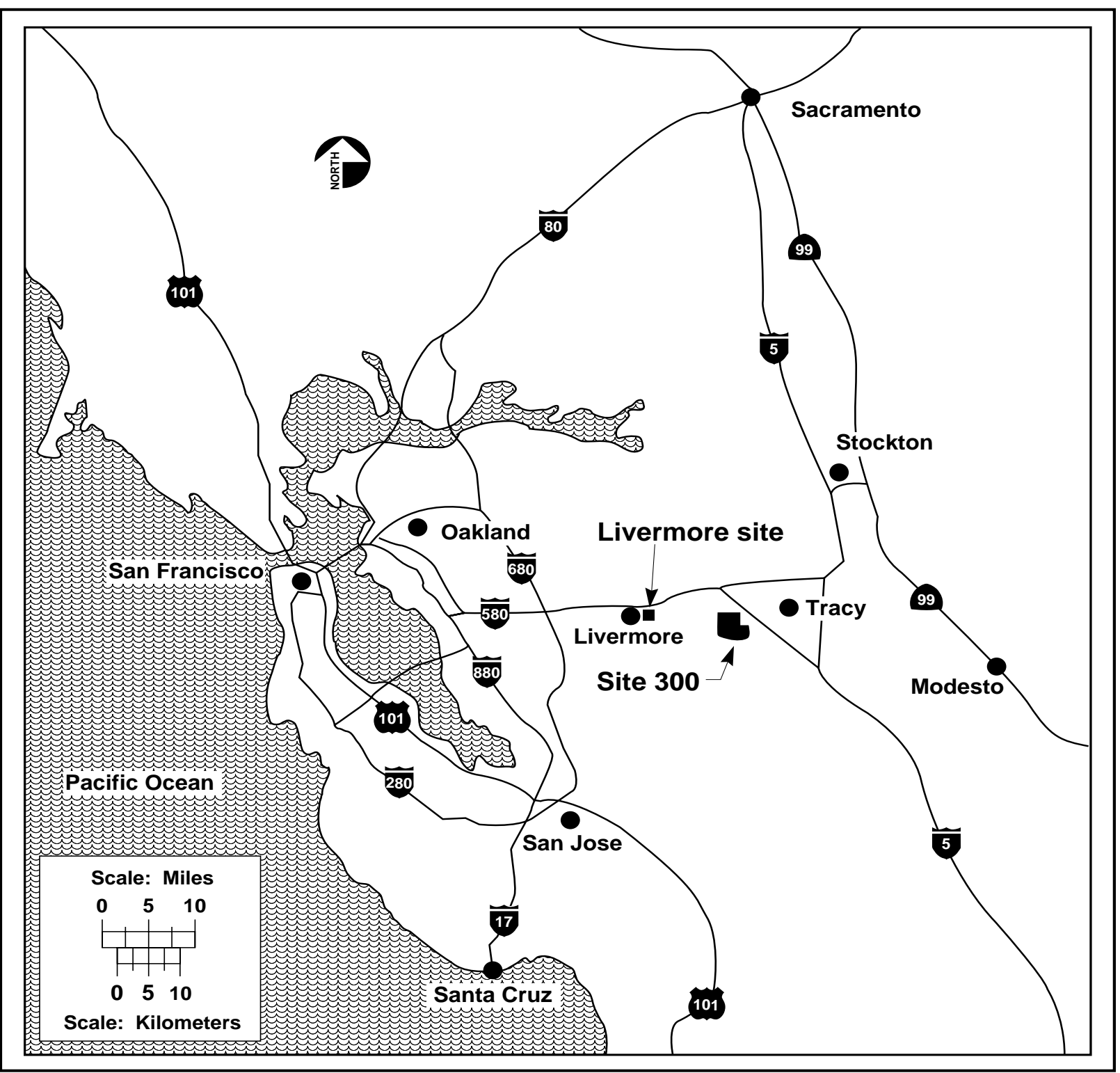

Figure 1. Locations of LLNL Livermore site and Site 300.

\section{Site 300}

Site 300, LLNL's Experimental Test Site, is located $24 \mathrm{~km}$ east of the Livermore site in the Altamont Hills of the Diablo Range and occupies an area of $30.3 \mathrm{~km}^{2}$. It is close to two other explosives-testing facilities; one owned by Primex Physics International but no longer operated, the other by SRI International. A State of California vehicular-recreation area is located nearby, and wind-turbine generators line the surrounding hills. The remainder of the surrounding area is in agricultural use, primarily pasture land for cattle and sheep. The nearest 
LLNL NESHAPs Report 2000

Table 1. Wind rose for LLNL's Livermore site at the 10-m level for 2000.

\begin{tabular}{|c|c|c|c|c|c|c|}
\hline \multicolumn{7}{|c|}{ Wind Speed Range (m/s) } \\
\hline Direction & $0.0-0.4$ & $0.5-2.9$ & $3.0-4.9$ & $5.0-6.9$ & $\geq 7.0$ & Total \\
\hline NNE & 0.24 & 2.43 & 1.47 & 0.35 & 0.11 & 4.6 \\
\hline NE & 0.24 & 4.28 & 1.98 & 0.17 & 0.00 & 6.7 \\
\hline ENE & 0.24 & 2.94 & 0.09 & 0.00 & 0.00 & 3.3 \\
\hline E & 0.24 & 2.47 & 0.00 & 0.00 & 0.00 & 2.7 \\
\hline ESE & 0.24 & 2.45 & 0.01 & 0.00 & 0.00 & 2.7 \\
\hline SE & 0.24 & 2.19 & 0.06 & 0.00 & 0.00 & 2.5 \\
\hline SSE & 0.24 & 2.08 & 0.20 & 0.05 & 0.02 & 2.6 \\
\hline $\mathrm{S}$ & 0.24 & 4.46 & 0.15 & 0.01 & 0.00 & 4.9 \\
\hline SSW & 0.24 & 6.90 & 1.50 & 0.43 & 0.16 & 9.2 \\
\hline SW & 0.24 & 8.81 & 8.11 & 2.65 & 0.33 & 20.1 \\
\hline WSW & 0.24 & 9.38 & 5.59 & 0.97 & 0.04 & 16.2 \\
\hline W & 0.24 & 5.99 & 6.38 & 1.05 & 0.00 & 13.7 \\
\hline WNW & 0.24 & 2.06 & 1.10 & 0.15 & 0.00 & 3.5 \\
\hline NW & 0.24 & 1.43 & 0.02 & 0.00 & 0.00 & 1.7 \\
\hline NNW & 0.24 & 1.47 & 0.04 & 0.02 & 0.00 & 1.8 \\
\hline $\mathrm{N}$ & 0.24 & 1.83 & 0.90 & 0.56 & 0.31 & 3.8 \\
\hline Total & 3.6 & 59.3 & 26.7 & 5.9 & 0.7 & 100 \\
\hline
\end{tabular}

Note: Values are frequency of occurrence (in percent). Columns and rows may not exactly sum to the listed totals due to rounding.

Table 2. Wind rose for LLNL's Site 300 at the 10-m level for 2000.

\begin{tabular}{lcccccc}
\hline & \multicolumn{5}{c}{ Wind Speed Range (m/s) } \\
Direction & $0.0-0.4$ & $0.5-4.9$ & $5.0-6.9$ & $7.0-10.9$ & $\geq 11.0$ & Total \\
\hline NNE & 0.22 & 1.40 & 0.05 & 0.05 & 0.00 & 1.7 \\
NE & 0.22 & 2.28 & 0.00 & 0.01 & 0.00 & 2.5 \\
ENE & 0.22 & 1.71 & 0.00 & 0.00 & 0.00 & 1.9 \\
E & 0.22 & 1.83 & 0.03 & 0.00 & 0.00 & 2.1 \\
ESE & 0.22 & 1.61 & 0.10 & 0.09 & 0.00 & 2.0 \\
SE & 0.22 & 2.29 & 0.34 & 0.28 & 0.00 & 3.1 \\
SSE & 0.22 & 2.35 & 0.11 & 0.20 & 0.08 & 3.0 \\
S & 0.22 & 2.40 & 0.27 & 0.13 & 0.00 & 3.0 \\
SSW & 0.22 & 1.88 & 0.10 & 0.07 & 0.02 & 2.3 \\
SW & 0.22 & 2.27 & 0.40 & 0.38 & 0.16 & 3.4 \\
WSW & 0.22 & 3.46 & 4.90 & 14.87 & 4.39 & 27.8 \\
W & 0.22 & 4.63 & 4.11 & 2.98 & 0.24 & 12.2 \\
WNW & 0.22 & 3.31 & 1.20 & 0.46 & 0.02 & 5.2 \\
NW & 0.22 & 4.83 & 1.49 & 0.84 & 0.14 & 7.5 \\
NNW & 0.22 & 6.55 & 2.82 & 2.45 & 1.00 & 13.0 \\
N & 0.22 & 3.86 & 2.44 & 2.03 & 0.61 & 9.2 \\
Total & $\mathbf{3 . 3}$ & $\mathbf{4 2 . 8}$ & $\mathbf{1 5 . 9}$ & $\mathbf{2 2 . 8}$ & $\mathbf{6 . 1}$ & $\mathbf{1 0 0}$ \\
\hline
\end{tabular}

Note: Values are frequency of occurrence (in percent). Columns and rows may not exactly sum to the listed totals due to rounding. 


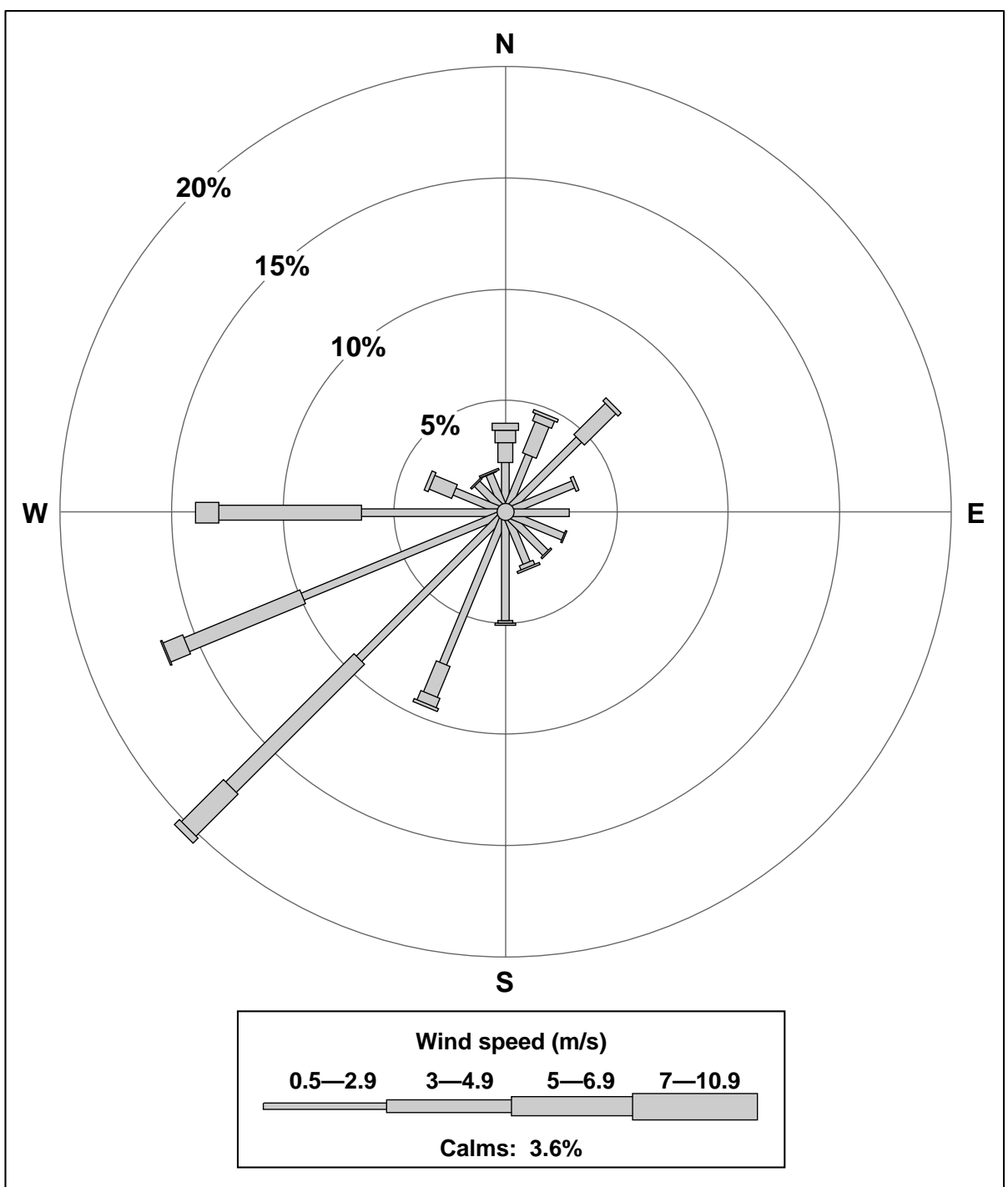

Figure 2. Wind rose showing the average annual wind speed, frequency of occurrence, and direction at the Livermore site, 2000.

residential area is the city of Tracy (population approximately 57,000), located $10 \mathrm{~km}$ to the northeast.

The topography of Site 300 is much more irregular than that of the Livermore site; it consists of a series of steep hills and ridges, which are oriented along a generally northwest/southeast trend, separated by intervening ravines. The elevation ranges from approximately $540 \mathrm{~m}$ in the northwestern portion of the site to $150 \mathrm{~m}$ at the southeast corner. The climate at Site 300 is similar to that of the Livermore site, with mild winters and dry summers. The complex topography of the site significantly influences local wind and temperature 
LLNL NESHAPs Report 2000

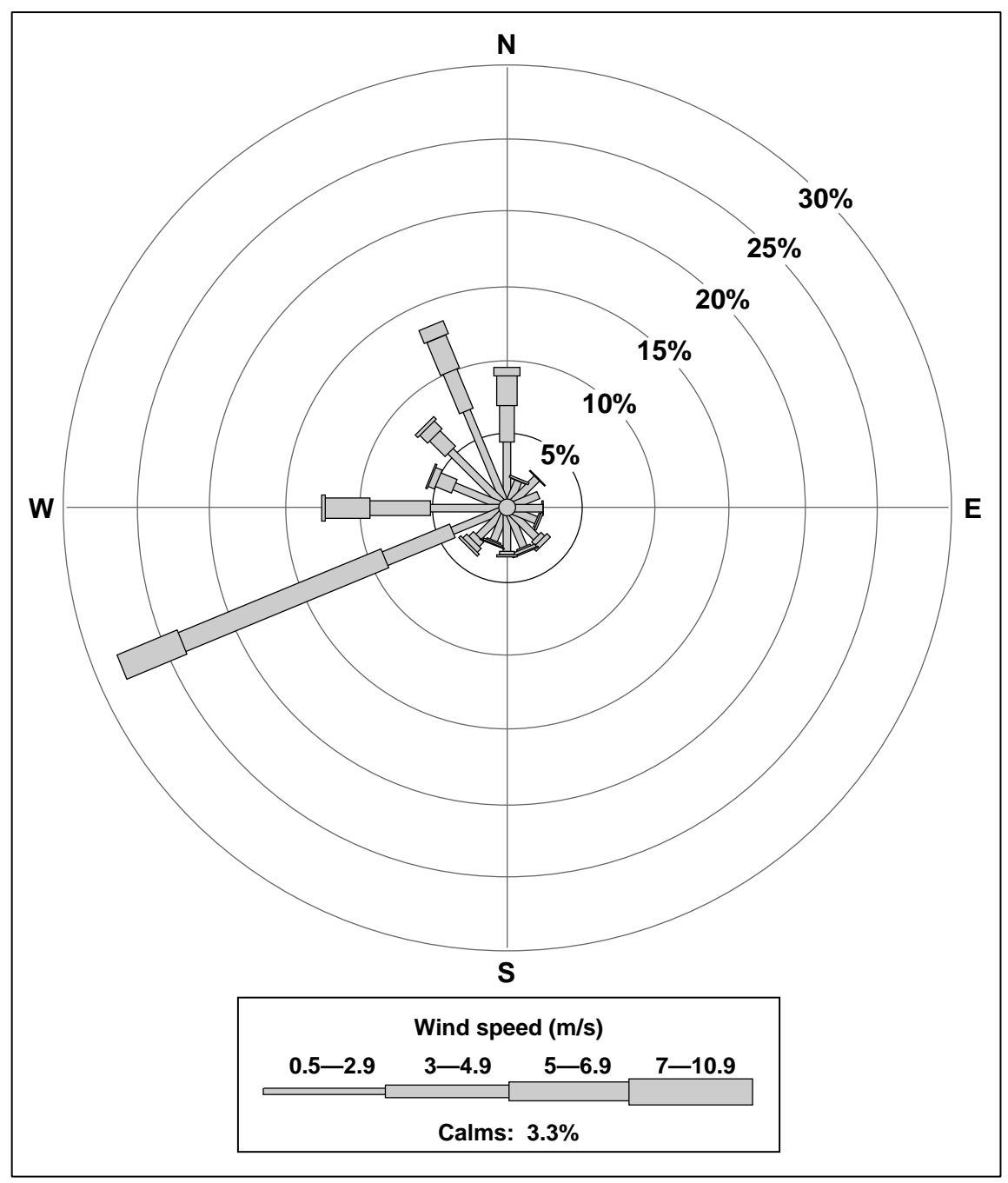

Figure 3. Wind rose showing the average annual wind speed, frequency of occurrence, and direction at Site 300, 2000.

patterns, making the temperature range somewhat more extreme than at the Livermore site. The 2000 annual wind data for Site 300 are shown in Table 2 and displayed as a wind rose in Figure 3. Prevailing winds are from the westsouthwest. As is the case at the Livermore site, precipitation is highly seasonal, with most precipitation occurring between October and April. Site 300 received $250 \mathrm{~mm}$ of precipitation during 2000. The mean annual temperature is about $16^{\circ} \mathrm{C}$. 
LLNL NESHAPs Report 2000

\section{Source Description}

Many different radioisotopes are used at LLNL for research purposes, including transuranic isotopes, biomedical tracers, tritium, mixed fission products, and others (Table 3). Radioisotope handling procedures and work enclosures are determined for each project, depending on the isotopes, the quantities being used, and the types of operations being performed. Radioisotope handling and working environments include glove boxes, exhaust hoods, and laboratory bench tops. Exhaust paths to the atmosphere range from triple HEPA (High Efficiency Particulate Air) filtered ventilation systems, to roof vents and stacks lacking abatement devices, to direct dispersal of depleted uranium during explosives testing at Site 300, to a variety of diffuse area sources.

Table 3. Radionuclides used at LLNL during 2000.

\begin{tabular}{llllll}
\hline${ }^{3} \mathrm{H}$ & ${ }^{54} \mathrm{Mn}$ & ${ }^{99} \mathrm{Mo}$ & ${ }^{147} \mathrm{Pm}$ & ${ }^{226} \mathrm{Ra}$ & ${ }^{239} \mathrm{Pu}$ \\
${ }^{7} \mathrm{Be}$ & ${ }^{55} \mathrm{Fe}$ & ${ }^{99} \mathrm{Tc}$ & ${ }^{148} \mathrm{Gd}$ & ${ }^{228} \mathrm{Th}$ & ${ }^{240} \mathrm{Pu}$ \\
${ }^{10} \mathrm{Be}$ & ${ }^{56} \mathrm{Co}$ & ${ }^{103} \mathrm{Ru}$ & ${ }^{151} \mathrm{Pm}$ & ${ }^{229} \mathrm{Th}$ & ${ }^{241} \mathrm{Am}$ \\
${ }^{13} \mathrm{~N}$ & ${ }^{57} \mathrm{Co}$ & ${ }^{106} \mathrm{Ru}$ & ${ }^{151} \mathrm{Sm}$ & $230 \mathrm{Th}$ & ${ }^{241} \mathrm{Pu}$ \\
${ }^{14} \mathrm{C}$ & ${ }^{58} \mathrm{Co}$ & $109 \mathrm{Cd}$ & $152 \mathrm{Eu}$ & $232 \mathrm{Th}$ & ${ }^{242} \mathrm{Cm}$ \\
${ }^{15} \mathrm{O}$ & ${ }^{59} \mathrm{Ni}$ & $113 \mathrm{Sn}$ & $154 \mathrm{Eu}$ & $232 \mathrm{U}$ & ${ }^{242} \mathrm{Pu}$ \\
$22 \mathrm{Na}$ & $60 \mathrm{Co}$ & $125 \mathrm{I}$ & $155 \mathrm{Eu}$ & $233 \mathrm{U}$ & ${ }^{243} \mathrm{Am}$ \\
${ }^{32} \mathrm{P}$ & $63 \mathrm{Ni}$ & $125 \mathrm{Sb}$ & $172 \mathrm{Hf}$ & $234 \mathrm{U}$ & ${ }^{244} \mathrm{Cm}$ \\
${ }^{33} \mathrm{P}$ & $65 \mathrm{Zn}$ & $131 \mathrm{I}$ & $173 \mathrm{Lu}$ & $235 \mathrm{U}$ & ${ }^{244} \mathrm{Pu}$ \\
${ }^{35} \mathrm{~S}$ & ${ }^{85} \mathrm{Sr}$ & $133 \mathrm{Ba}$ & $185 \mathrm{~W}$ & $236 \mathrm{Pu}$ & ${ }^{246} \mathrm{Cm}$ \\
${ }^{36} \mathrm{Cl}$ & ${ }^{88 \mathrm{Y}}$ & $134 \mathrm{Cs}$ & $195 \mathrm{Au}$ & $236 \mathrm{U}$ & ${ }^{248} \mathrm{Cm}$ \\
${ }^{40} \mathrm{~K}$ & $90 \mathrm{Sr}$ & ${ }^{137} \mathrm{Cs}$ & $195 \mathrm{mPt}$ & $237 \mathrm{~Np}$ & ${ }^{249} \mathrm{Cf}$ \\
${ }^{41} \mathrm{Ar}$ & $90 \mathrm{Y}$ & $140 \mathrm{Ba}$ & $207 \mathrm{Bi}$ & $237 \mathrm{U}$ & ${ }^{250} \mathrm{Cf}$ \\
${ }^{41} \mathrm{Ca}$ & $94 \mathrm{Nb}$ & $141 \mathrm{Ce}$ & $209 \mathrm{Po}$ & $238 \mathrm{Pu}$ & ${ }^{252} \mathrm{Cf}$ \\
$46 \mathrm{Sc}$ & $95 \mathrm{Nb}$ & $144 \mathrm{Ce}$ & $210 \mathrm{~Pb}$ & $238 \mathrm{U}$ & \\
$51 \mathrm{Cr}$ & $95 \mathrm{Zr}$ & $147 \mathrm{Nd}$ & $223 \mathrm{Ra}$ & $239 \mathrm{~Np}$ & \\
\hline
\end{tabular}




\section{SECTION II. Air Emission Data}

\section{Sources}

At LLNL, there are emissions from point sources, such as stacks and roof vents, and diffuse area sources, including areas of known contamination. Hazardous Waste Management operations at Building 514 and at the Building 612 Yard and other Livermore-site sources external to buildings are treated as diffuse area sources. Detailed information is given in Attachment 1 for emissions from the Livermore-site radiological operations that took place during 2000.

Similarly, detailed information is given in Attachment 1 for experiments at the Site 300 explosives testing facilities (Buildings 801 and 851 and their associated firing tables). Explosives tests are treated as point sources for demonstration of NESHAPs compliance. Site 300 is also treated as a diffuse area source of residual tritium and depleted uranium contamination.

\section{Radionuclide Usage Inventory Update and Effective Dose Equivalent (EDE) Calculations}

For this year's report, covering activities in 2000, we updated the radionuclide usage inventories in all facilities. Radionuclide usage inventory forms, with guidance for completing them, were sent to all unmonitored facilities having the potential for radionuclide emissions to the air. The forms were completed by experimenters, and certified by facility managers. Radionuclide usage inventories for all Site 300 explosives experiments and assessments of source terms for known diffuse sources at both sites were also updated.

Dose assessment modeling runs were conducted for all diffuse sources and for all point sources. The model used was CAP88-PC (see Section III); we incorporated calendar year 2000 on site meteorological data (wind, precipitation, and temperature) along with the 2000 radionuclide usage inventory or stack effluent monitoring data. Annual dose is reported as whole-body EDE expressed in units of mrem (followed by $\mu \mathrm{Sv} ; 1 \mathrm{mrem}=10 \mu \mathrm{Sv}$ ). When reasonable to do so, modeling runs were combined by building, rather than performing a separate model run for each stack or room. This is permitted by the 1995 Memorandum of Understanding between the U.S. EPA and the DOE concerning radionuclide NESHAPs.

A generalized description of each facility and its operations is provided in Attachment 1. The following information is shown for each listed emission point or stack: 
- $\quad$ Building and room number(s)

- $\quad$ Specific stack identification code(s)

- Generalized operations in the room(s) or area(s)

- $\quad$ Radionuclides utilized in the operation

- Annual radionuclide usage inventory with potential for release (by isotope, in curies)

- $\quad$ Physical state factors (by isotope)

- $\quad$ Stack parameters

- Emission control devices and emission control device abatement factors

- $\quad$ Estimated or measured annual emissions (by isotope)

- $\quad$ Distance and direction to the site-wide maximally exposed individual (SW-MEI)

- $\quad$ Calculated EDE to the SW-MEI for each specific source

- $\quad$ Distance and direction to the maximally exposed individual (MEI) for each specific source

- Calculated EDE to the MEI (source term not adjusted for emission controls)

- $\quad$ Source category

A more complete description of these terms is provided in the introductory material to Attachment 1.

The radionuclides shown in the attachment are those from specific emission points where there was a potential for air emissions. If radionuclides were present, but encapsulated or sealed for the entire year, radionuclides, annual usage inventories, and emissions are not listed.

Actual measurements of radioactivity in air and effluent flow are the basis for reported emissions from continuously monitored sources. LLNL facilities that had continuously monitored discharge points in 2000 are Buildings 175, 177, 251, 331, 332, and 491. Discharge points at Buildings 175, 177, 251, 332, and 491 were monitored for gross alpha and gross beta activity. Building 331 stack discharges were monitored for tritium.

\section{Tritium Monitoring and Dose Assessment}

Operations in the Tritium Facility (Building 331) released a total of $40 \mathrm{Ci}$ $\left(1.5 \times 10^{12} \mathrm{~Bq}\right)$ of tritium. Of this, approximately $35 \mathrm{Ci}\left(1.3 \times 10^{12} \mathrm{~Bq}\right)$ were released as tritiated water (HTO). The remaining $12.5 \%$ of the tritium released, $4.8 \mathrm{Ci}$ $\left(1.8 \times 10^{11} \mathrm{~Bq}\right)$, was elemental tritium gas $(\mathrm{HT})$. The highest single weekly stack 


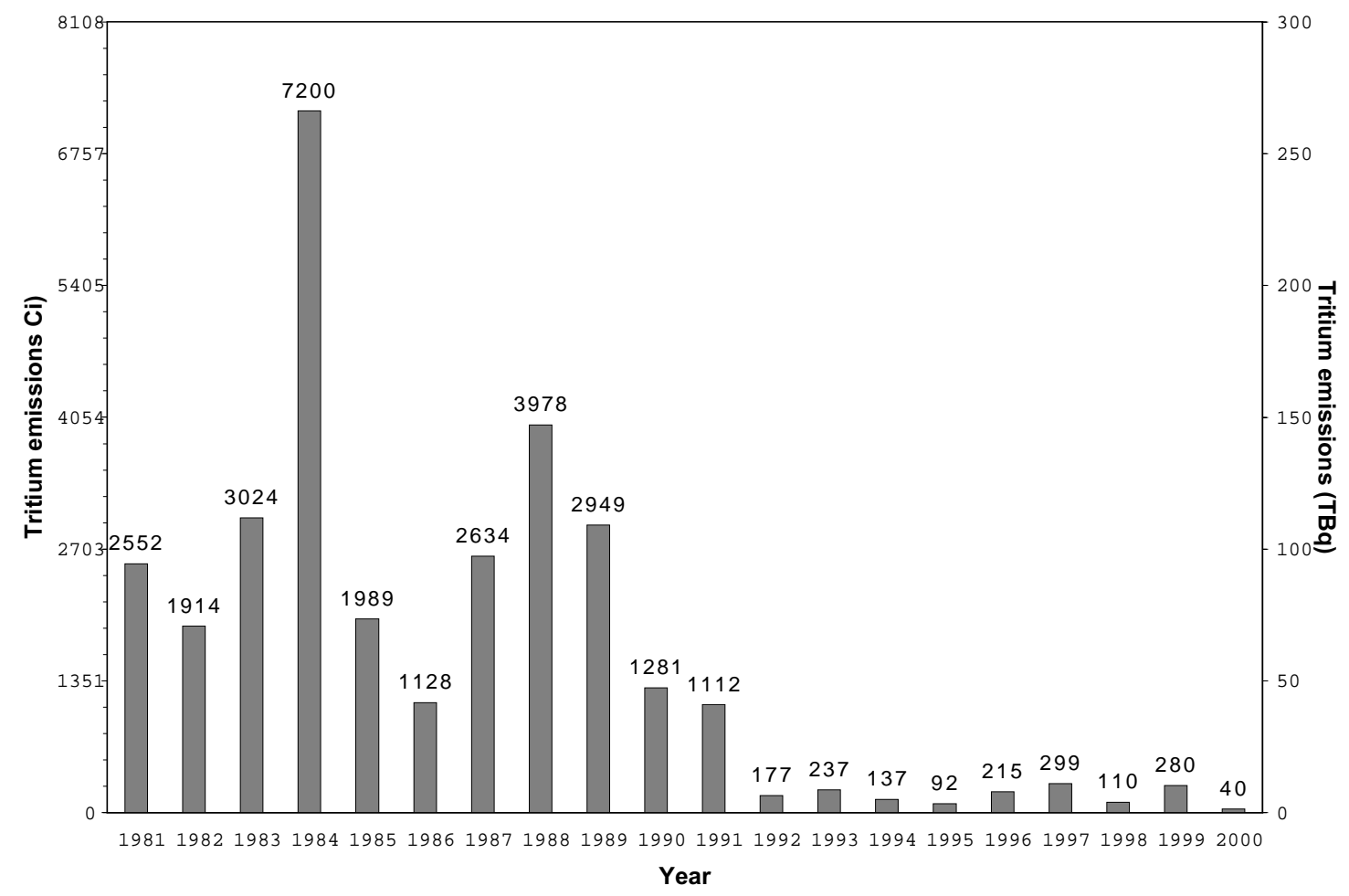

Figure 4. Combined HT and HTO emissions from the Tritium Facility, 1981-2000. Note: The plot of Tritium Facility emissions differs in this report as compared with similar plots in previous reports, in which the Tritium Facility emissions were overstated for the years 1981-1987. The previous reports contained the total LLNL emissions of HTO and HT, not just Tritium facility emissions.

emission from the facility was $8.1 \mathrm{Ci}\left(3.0 \times 10^{11} \mathrm{~Bq}\right)$, of which $7.7 \mathrm{Ci}\left(2.8 \times 10^{11} \mathrm{~Bq}\right)$ was HTO.

Building 331 tritium emissions, as measured by stack monitoring, remained considerably lower in 2000 than emissions that occurred during the 1980s. The reduced emissions in 2000 were primarily the result of a reduction in programmatic work compared to the previous years. Over the next five years, an increasing trend in emissions may occur as research and development work is performed for new programmatic efforts. However, engineered controls designed to contain and recapture tritium leakage from this effort should maintain relatively low emissions. Figure 4 illustrates the combined HTO and HT emissions from the facility since 1981.

To evaluate the dose from tritium releases, we used the EPA-required CAP88-PC model. LLNL also continues to comply with the EPA's direction that LLNL 
evaluate dose from the combined HT and HTO emissions from the Tritium Facility as if they were all HTO.

However, the CAP88-PC model ignores the chemical forms of tritiated molecules; all forms are treated as HTO and, therefore, have the same dose consequences. In fact, the doses from exposure to the two major forms of tritiated molecules, HTO and HT, differ greatly. HTO enters the body by ingestion, inhalation, and dermal absorption. Ingested HTO is distributed throughout the entire body and eliminated at the same rate as body water (apart from the small fraction metabolized). Inhaled HTO dissolves in the fluids of the lung and is absorbed. HT enters the body primarily via inhalation, and very little is retained, most being exhaled. In addition, HT is a biologically inert gas and imparts an extremely low dose relative to tritiated water. Only $0.004 \%$ of inhaled HT is converted to HTO and contributes dose to the body (Pinson, E.A., 1951, The body absorption, distribution, and excretion of tritium in man and animals. Los Alamos Scientific Laboratory of the University of California, Los Alamos, NM, LA-1218). Even the limiting dose from HT (the beta dose to the lung) is only $0.01 \%$ of the equivalent dose from HTO (Pinson, 1951; International Commission on Radiological Protection, 1995, Age dependent doses to members of the public from intake of radionuclides, Part 4, Inhalation Dose Coefficients. Oxford: Pergamon Press; ICRP Publication 71; Ann. ICRP 25[3\&4]).

HT requires conversion to HTO (oxidation) to produce a significant dose. In the environment, this conversion predominately occurs in soil (Brown, Ogram and Spencer, 58 Health Physics, 171-181, 1990) and, to a lesser extent, in vegetation following deposition. CAP88-PC, because it only includes HTO, does not account for HT to HTO conversion.

An additional form of tritium for which exposure should be modeled (but which is ignored by CAP88-PC) is organically bound tritium (OBT). OBT can be formed by plant or animal metabolism of HTO. The dose rate conversion factor for ingestion of OBT is about 2.3 times larger than that for ingestion of HTO in the free water of plants and animals.

A simple tritium model, NEWTRIT, has been developed to account for ingestion dose from OBT and for doses from releases of HT (Peterson, S-R. and P.A. Davis, 2001, Tritium Doses from Chronic Atmospheric Releases: A New Approach Proposed for Regulatory Compliance". Accepted upon revision by Health Physics, UCRL-JC-141535). For this report, LLNL has used the NEWTRIT model, in addition to CAP88-PC to estimate doses from significant sources of tritium emissions. These doses are presented throughout the report. For example, the dose to the SW-MEI resulting from combined emissions of HT and HTO from 
the Tritium Facility as modeled by CAP88-PC in 2000 is 0.0095 mrem $(0.095 \mu \mathrm{Sv})$. Modeling the HTO and HT emissions from the Tritium Facility as implemented in the NEWTRIT addition to CAP88-PC results in an estimated dose to the SWMEI of 0.0063 mrem $(0.063 \mu \mathrm{Sv})$. A brief discussion of the NEWTRIT model is presented in Attachment 2.

\section{Gross Alpha and Gross Beta Monitoring and Dose Assessment}

For most discharge points at the other facilities where continuous stack sampling is performed, the results are below the minimum detectable concentration (MDC) of the analysis; sometimes as few as 1 to 4 samples (out of 25 to 50 per year) have concentrations greater than the MDC. Generally, these few samples having results above the MDC are only marginally above the MDC. Use of zero values for this type of data can be justified based on knowledge of the facility, the use of tested, multiple stage, HEPA filters in all significant release pathways, and alpha spectroscopy based isotopic analyses of selected air sampling filters. These isotopic analyses demonstrate that detected activity on air sampling filters comes from naturally occurring radionuclides, such as radon daughters, e.g., polonium, on the air sampling filters. In addition, because of exhaust configurations at some facilities, the monitoring systems sometimes sample air from the ambient atmosphere along with the HEPA filtered air from facility operations, giving rise to background atmospheric radioactivity being collected. Because of these considerations, the emissions from such facility operations are reported as zero. Consequently, there are no dose consequences, and doses reported for these operations are also zero. Furthermore, even if the MDC values are used in calculations of the emission estimates for these facilities, which would be an extremely conservative approach, the total dose attributable to LLNL activities is not significantly affected.

In 2000, a significant number of samples collected throughout the year from one emission point at Building 251 (the unhardened area) yielded gross alpha results greater than the MDC. We use gross alpha as the primary indicator of potential emissions from Building 251, where operations had involved the use of uranium and transuranic materials (the Building 251 facility is in program standby mode). Gross beta results are used as a further corroboration of those gross alpha results having concentrations above the MDC. The gross alpha monitoring concentrations for Building 251 ranged from $-2.5 \times 10^{-15} \mathrm{Ci} / \mathrm{m}^{3}$ $\left(-9.3 \times 10^{-5} \mathrm{~Bq} / \mathrm{m}^{3}\right)$ to $1.9 \times 10^{-14} \mathrm{Ci} / \mathrm{m}^{3}\left(7.0 \times 10^{-4} \mathrm{~Bq} / \mathrm{m}^{3}\right)$. Because of the number of samples with values above the MDC, we have taken a conservative approach and are reporting gross alpha and gross beta measurements as actual emissions. The gross alpha and gross beta emissions for Building 251 were determined to be $7.0 \times 10^{-9} \mathrm{Ci} / \mathrm{y}\left(2.6 \times 10^{2} \mathrm{~Bq} / \mathrm{y}\right)$ and $9.9 \times 10^{-8} \mathrm{Ci} / \mathrm{y}\left(3.7 \times 10^{3} \mathrm{~Bq} / \mathrm{y}\right)$. If the results are 
LLNL NESHAPs Report 2000

considered facility emissions, the resulting radiological dose determined with CAP88-PC modeling is $1.4 \times 10^{-6}$ mrem $\left(1.4 \times 10^{-5} \mu \mathrm{Sv}\right)$, less than the dose due to many other facility emissions at the Livermore site. 


\section{SECTION III. Dose Assessment}

\section{Description of the Air Dispersion and Dose Model}

Estimates of individual and collective radiological doses to the public from all point sources and many diffuse sources at LLNL were obtained using the EPAdeveloped computer code CAP88-PC. Generally, CAP88-PC, version 1, is used because of the flexibility it affords in entering distances from the source. CAP88PC, version 2, was used in some of the QC model runs. Both model versions are EPA-approved. They are substantially the same, and contain the same dispersion and dose calculations; the major difference is the user interface. The four principal pathways-internal exposures from inhalation of air, ingestion of foodstuff and drinking water, external exposures through irradiation from contaminated ground, and immersion in contaminated air-are evaluated by CAP88-PC. The doses are expressed as whole-body effective dose equivalents (EDEs), in units of mrem/y $(1 \mathrm{mrem}=10 \mu \mathrm{Sv})$. Separate doses for Livermore site and Site 300 point source emissions (e.g., stack emissions) and diffuse source emissions are reported.

Three potential doses are emphasized: (1) The dose to the site-wide maximally exposed individual (SW-MEI), which combines the effects of all emission points, for comparison to the $10 \mathrm{mrem} / \mathrm{y}(100 \mu \mathrm{Sv} / \mathrm{y})$ standard; (2) the maximum dose to any member of the public (assumed to be at the LLNL fence line), in any direction, due to each unabated emission point on the site to determine the need for continuous monitoring; and (3) the collective dose to populations residing within $80 \mathrm{~km}$ of the two LLNL sites, adding the products of individual doses received times the number of people receiving them.

\section{Summary of Model Input Parameters}

\section{General Model Inputs}

Attachment 1 details the key identifiers and input parameters for the CAP88-PC model runs. These include building number; stack ID; isotope(s); emission rate in curies per year $\left(1 \mathrm{Ci}=3.7 \times 10^{10} \mathrm{~Bq}\right)$; and stack parameters, including height, diameter, and emission velocity.

\section{Meteorological Data}

All model runs used actual 2000 Livermore-site and Site 300 meteorological data, collected from the meteorological towers for each site. At these towers, wind speed and direction are sampled every few seconds, temperature sampled every minute, and all are averaged into quarter-hour increments, time tagged, and 
computer recorded. The data are converted into a CAP88-PC input wind file using EPA guidelines.

\section{Surrogate Radionuclides}

CAP88-PC contains a library of 265 radionuclides; however, it does not contain all the radionuclides in use at LLNL. As a consequence, it was necessary in a few cases to use surrogate radionuclides to estimate EDEs. Attachment 3 shows the surrogate radionuclides used in CAP88-PC. The selection of a suitable surrogate is based upon several criteria, including metabolically similar behavior and similar modes of decay and decay energies of the radiation type of the isotope of interest. Once a surrogate is selected, the equivalent source term is adjusted by the product of the initial inventory of the isotope of interest and the ratio of the effective dose equivalent of the surrogate to that of the isotope of interest. In some cases, experimenters did not have isotopic analyses of mixtures of radionuclides, and they identified the radionuclides used as "gross alpha," "gross beta," "gross gamma," or "mixed fission products" (MFP). In these cases, ${ }^{239} \mathrm{Pu}$ was used as the surrogate for gross alpha, ${ }^{137} \mathrm{C}$ s was used as the surrogate for gross gamma, and $90 \mathrm{Sr}$ was used as the surrogate for gross beta and mixed fission products to provide conservative dose estimates.

\section{Population Inputs}

Population distributions centered on the two LLNL sites were compiled from the LandScan Global Population 1998 Database developed by Dr. Jerome Dobson at Oak Ridge National Laboratory. The population data files (distribution of population with distance and direction) used in the 2000 modeling effort are described in Section VI under "Collective Effective Dose Equivalent."

\section{Land Use and Agricultural Inputs}

Options for model inputs regarding agricultural characteristics and land use are established by the EPA, and the particular designation selected can strongly influence the ingestion dose received by the population being evaluated. The "user entered" option was again selected for the CAP88-PC modeling effort for 2000. The values entered corresponded to the "local agriculture" option (i.e., everything is home produced), with one exception-all milk consumed was assumed to be imported for individual dose assessment. The assumption that all milk comes from local cows is not supported by the agricultural activities conducted in the area.

\section{Emission Source Terms}

The source term(s) from each emission point in the calculations was determined by one of two methods: For continuously monitored sources, the sampling data (curies released per unit time) for each radionuclide were used directly. For 
unmonitored facilities, the radionuclide usage inventories, together with time factors and EPA-specified physical state factors, are used to estimate the potential emissions to air from a source. The time factors are used to adjust for the fact that the radionuclide may not always be in the same facility all year or may be encapsulated or enclosed for a substantial part of the year. The time factors are chosen to allow a reasonable estimate of the amount of radioactive material that may potentially be released into the atmosphere. The EPA-specified factors for potential release to air of materials in different physical states (solid, liquid, powder, or gas) are those stated in 40 CFR Part 61, Appendix D. If the material was an unconfined gas, then the factor 1.0 was used; for liquids and powders, $1.0 \times 10^{-3}$ was used; and for solids, $1.0 \times 10^{-6}$ was used. The U.S. EPA has granted approval for LLNL to use alternative physical state factors for elemental uranium, uranium/niobium alloy, and elemental plutonium. Table 4 provides the approved temperatures for application of the physical state factor for each material.

These factors are allowed provided that the material is not intentionally dispersed to the environment and that the processes do not alter its chemical form. The physical state dependent release fraction and the time factor are used to adjust (by multiplication) the total annual usage inventory to yield the potential annual release to air. In addition, emission control abatement factors (40 CFR 61, Appendix D), when applicable, were applied. Each HEPA filter stage was given a 0.01 abatement factor. (However, abatement factors were not used to evaluate compliance with the $0.1 \mathrm{mrem}[1 \mu \mathrm{Sv}]$ standard that determines the need for continuous monitoring at a facility.) The use of actual monitoring data is much more direct, and presumably more accurate, than using assumptions based on usage inventory, time factors, release fractions, and emission control factors.

Table 4. List of materials for which exemption from the required assumption that any material heated above $100^{\circ} \mathrm{C}$ is a gas and temperatures at which the physical state factors apply.

\begin{tabular}{llllr}
\hline Material & $\begin{array}{c}\text { Solid physical } \\
\text { state factor }\end{array}$ & $\begin{array}{c}\text { Liquid physical } \\
\text { state factor }\end{array}$ & $\begin{array}{c}\text { Gas Physical } \\
\text { state factor }\end{array}$ & $\begin{array}{c}\text { Year } \\
\text { Approved }\end{array}$ \\
\hline Elemental uranium & $<1100^{\circ} \mathrm{C}$ & Between $1100^{\circ} \mathrm{C}$ and $3000^{\circ} \mathrm{C}$ & $>3000^{\circ} \mathrm{C}$ & 1996 \\
Uranium/niobium alloy & $<1000^{\circ} \mathrm{C}$ & Between $1100^{\circ} \mathrm{C}$ and $3000^{\circ} \mathrm{C}$ & $>3000^{\circ} \mathrm{C}$ & 2001 \\
Elemental plutonium & $<600^{\circ}$ & Between $600^{\circ} \mathrm{C}$ and $3000^{\circ} \mathrm{C}$ & $>3000^{\circ} \mathrm{C}$ & 2001 \\
\hline
\end{tabular}


LLNL NESHAPs Report 2000

\section{Site-Wide Maximally Exposed Individual}

For LLNL to comply with the NESHAPs regulations, the LLNL site-wide maximally exposed individual cannot receive an EDE greater than $10 \mathrm{mrem} / \mathrm{y}$ $(100 \mu \mathrm{Sv} / \mathrm{y})$. The site-wide maximally exposed individual (SW-MEI) is defined as the hypothetical member of the public at a single residence, school, business, or office who receives the greatest LLNL induced EDE from the combination of all radionuclide source emissions.

At the Livermore site, the SW-MEI for 2000 was located at the UNCLE Credit Union, about $10 \mathrm{~m}$ outside the controlled eastern fence line of the site, but about $10 \mathrm{~m}$ within the perimeter of the site property, as shown in Figure 5. To determine the location of the 2000 SW-MEI, CAP88-PC results from multiple sources were combined. Sources were selected to include those expected to give

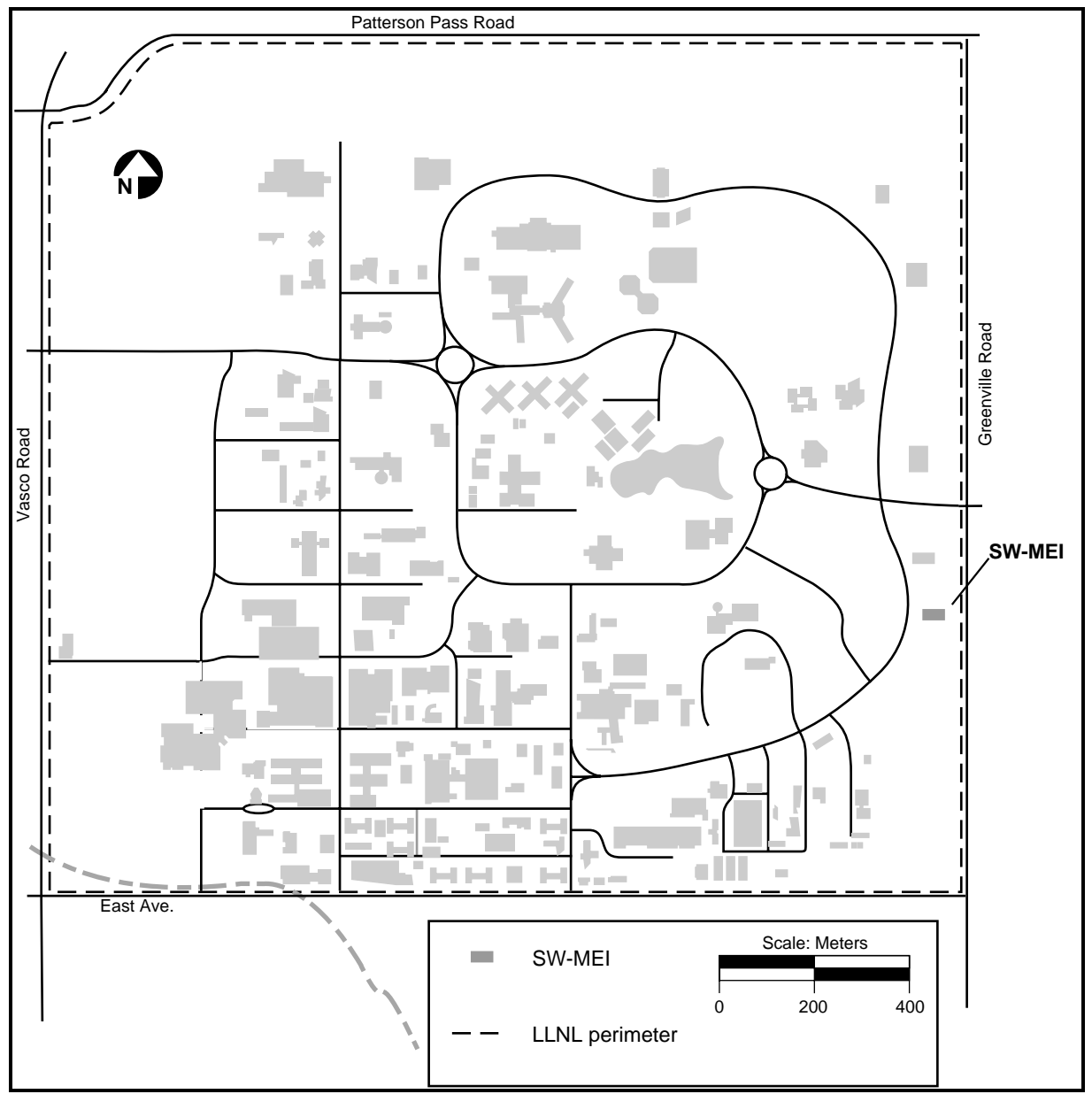

Figure 5. Location of Site-Wide Maximally Exposed Individual (SW-MEI) at the Livermore site, 2000. 
significant contributions to the EDE. These consisted of Building 331 point and diffuse sources and the Building 612 diffuse source. Because EDE results from CAP88-PC depend on the location of the specified source, direct summing of results from multiple sources can only be accomplished using an interpolation method. To do this, the location of each selected source relative to a common location (the Livermore-site center) and a set of receptor locations (where the combined EDEs from the selected sources were to be evaluated), also relative to the site center, were specified in the modeling efforts that supported determination of the SW-MEI. The receptor locations included 48 equally spaced directions from the site center and 4 additional receptor locations along the eastern Livermore-site boundary. The interpolation method was used to calculate the EDEs for the desired set of receptor locations for each source. These resulting interpolated EDEs for each source, now for the same set of locations, were then summed, and the SW-MEI determined.

At Site 300, the 2000 SW-MEI was located at the boundary with the Carnegie State Vehicle Recreation Area, managed by the California Department of Parks and Recreation, as shown in Figure 6. The location of the SW-MEI at Site 300 in 2000 was dominated by the tests conducted at Building 851; no other sources made a sufficient contribution to the dose to alter the location of the SW-MEI. Previously, the Site 300 SW-MEI was located at "Bunker 2" operated by Primex Physics International. However, Primex terminated operations at the facility, so there were no exposed individuals at that location. The new location for the SWMEI is approximately $3.2 \mathrm{~km}$ south southeast of the firing table at Building 851 .

In Attachment 1, the distance and direction to the respective SW-MEI are shown for each facility at each site. Doses to the site specific SW-MEIs were evaluated for each source and then totaled for site specific evaluations against the $10 \mathrm{mrem} / \mathrm{y}$ $(100 \mu \mathrm{Sv})$ dose standard (see "Total Dose Estimate" in Section IV).

\section{Maximally Exposed Public Individual}

To assess compliance with the requirement for continuous monitoring (potential dose greater than $0.1 \mathrm{mrem} / \mathrm{y}[1.0 \mu \mathrm{Sv} / \mathrm{y}]$ ), emissions must be individually evaluated from each point source; the location of the maximally exposed public individual (MEI) is generally different for each emission point. The maximum dose at a location of unrestricted public access typically occurs at a point on the site perimeter. Therefore, it is often referred to as the maximum "fence line" dose, although the off-site maximum dose could occur some distance beyond the perimeter. (This could happen, e.g., when a stack is close to the perimeter; however, for all emission points at the Livermore site and Site 300 , calculations show that ground level concentrations of radionuclides decline monotonically beyond LLNL boundaries.) As stipulated by the regulations in 


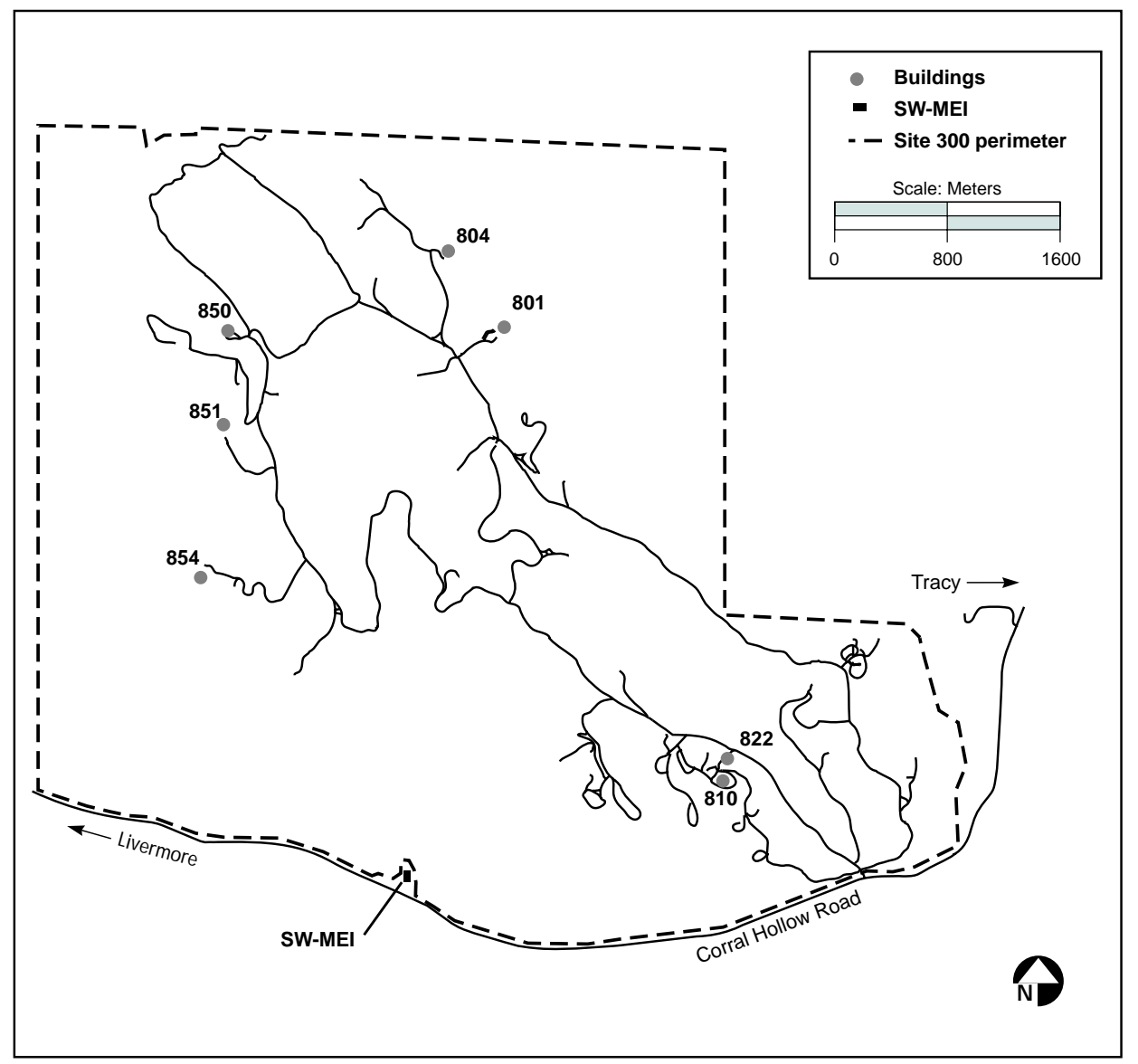

Figure 6. Location of Site-Wide Maximally Exposed Individual (SW-MEI) at Site 300, 2000.

40 CFR Section 61.93 (b)(4)(ii), modeling for assessment of continuous monitoring requirements assumed unabated emissions (i.e., no credit was taken for emission abatement devices, such as filters). Attachment 1 provides, for each point source, the dose to the MEI and the distance and direction to the LLNL fence line where the MEI is located.

\section{Special Modeling Challenges}

Among the sources at LLNL, explosives tests using depleted uranium at Site 300 and diffuse sources at both sites required special attention.

Site 300 Explosives Experiments: Some of the explosives assemblies for Site 300 explosives experiments contain depleted uranium. The explosives assemblies are placed on an open air firing table and detonated. Only limited data are available to characterize the initial state of the cloud of explosive decomposition products created by the detonation because properties of the cloud 
are not routinely measured in the experiments. Empirical scaling laws can be used, however, to define the cloud using the radionuclide usage and explosives inventories. Isotopic ratios for depleted uranium are used; the three uranium isotopes with atomic weights 238,235 , and 234 occur in the weight percentages $99.8,0.2$, and $5 \times 10^{-4}$. Their masses are multiplied by their specific activities to determine the total activity for each isotope in the cloud. It is assumed that all the uranium is dispersed into the cloud, and the median particle size is assumed to be the CAP88-PC default value of $1 \mu \mathrm{m}$. The assumption that all uranium is aerosolized and dispersed as a cloud results in a highly conservative off-site dose estimation-we believe a more realistic release-to-air fraction for the uranium is no greater than 0.2 , but we lack sufficient data to use a value other than 1.0. CAP88-PC simulates each shot as a low level, steady state, stack type emission occurring over one year. An alternative modeling methodology for treating these short duration explosive events was submitted for approval in 1992, but LLNL was directed by EPA to use the CAP88-PC code for these calculations.

Diffuse Sources: Diffuse emissions are generally area sources external to buildings, as discussed in Section IV, below. The dose assessments for diffuse sources can be derived from radionuclide usage inventory data, from environmental surveillance monitoring data, or from samples of contaminated materials.

\section{Modeling Documentation}

Copies of individual model runs, including input parameters and resultant calculated doses, are on file with the Terrestrial \& Atmospheric Monitoring \& Modeling Group (TAMM) of the Environmental Protection Department at LLNL.

\section{Point Source Summary}

The 2000 calculated EDE to the SW-MEI from Livermore-site point sources was $0.017 \mathrm{mrem}(0.17 \mu \mathrm{Sv})$. (The dose from point sources includes HT emissions modeled as HTO as directed by EPA Region IX.) The 2000 dose is less than the 1999 reported EDE from Livermore-site point sources of $0.094 \mathrm{mrem}(0.94 \mu \mathrm{Sv})$. The differences in EDE to the SW-MEI can be attributed to differences in reduced programmatic activity and, consequently, reduced emissions from the Tritium Facility (Building 331) where emissions accounted for $0.088 \mathrm{mrem}(0.88 \mu \mathrm{Sv})$ in 1999, compared to 0.0095 mrem $(0.095 \mu \mathrm{Sv})$ in 2000.

The calculated EDE to the SW-MEI at Site 300 was calculated to be 0.015 mrem $(0.15 \mu \mathrm{Sv})$ from point source emissions. This entire dose resulted from Building 851 firing table emissions in the course of explosives experiments. The 2000 EDE is a decrease from the $0.034 \mathrm{mrem}(0.34 \mu \mathrm{Sv})$ dose modeled for 1999. The decrease 
LLNL NESHAPs Report 2000

in dose is primarily the result of a decrease in the number of experiments in which depleted uranium was used.

All the dose evaluations from point source emissions, and those from most diffuse sources discussed below, were made using the EPA-mandated CAP88-PC dispersion model. They result in levels of public exposure well below the EPA standard, which limits the whole-body EDE to members of the public from DOE activities to $10 \mathrm{mrem} / \mathrm{y}(100 \mu \mathrm{Sv} / \mathrm{y})$. Discussion of the contribution to EDE to members of the public from diffuse sources is presented in Section IV. 


\section{SECTION IV. Additional Information}

\section{Construction and Modifications}

Proposed facilities and significantly modified operations are assessed for NESHAPs requirements during the National Environmental Policy Act (NEPA) process. Under NEPA, all proposed projects or actions that might involve NESHAPs issues or concerns-not just pertaining to radionuclides but to toxic air contaminants as well-are reviewed and evaluated. If the proposal includes operations that require a NESHAPs assessment, necessary modeling is conducted. If insufficient information is available for modeling at the time the NEPA documents are prepared, LLNL includes in the NEPA documents a statement that NESHAPs review, modeling, and monitoring requirements will be met. It is the responsibility of the individual project proponent to supply the specific information required for any NESHAPs modeling, analysis, and review that must be completed before operations described in the document are initiated.

Three new facilities are currently under construction. All of these facilities were assessed prior to construction for compliance with NESHAPs. Effluent sampling systems are planned for all three. These facilities are the Contained Firing Facility (CFF) at Site 300, and the Decontamination Waste Treatment Facility (DWTF) and the National Ignition Facility (NIF) at the Livermore site.

The CFF project will allow containment of some explosives tests currently conducted outdoors at Site 300's Building 801. The CFF project consists of an enclosed firing chamber, a support facility and a diagnostic equipment facility. The construction of CFF is now complete, and testing of the facility with nonradiological materials is underway. CFF plans include preliminary stack monitoring for radioactive particulate emissions to assess if continuous monitoring is required.

The DWTF is a waste handling facility that will have improved air emissions controls and will enable the handling of additional waste streams. Phase I construction (site preparation and installation of underground utilities) has been completed. Construction of the solid waste processing building, the storage building, and the office building were completed in 1998. Construction of the building housing the stack, air handling systems and liquid waste processing operations began in December 1999, following the issuance of the RCRA Hazardous Waste Facility permit from the State of California. The DWTF stack will be monitored for tritium and radioactive particulate emissions. Most of the 
stack monitoring equipment has been ordered and the tritium monitoring equipment has been received.

The National Ignition Facility (NIF) will contain the world's largest laser, a research tool allowing scientists to recreate on earth conditions equivalent to the center of the sun. The NIF will focus 192 extremely powerful laser beams onto a BB-sized capsule of deuterium and tritium, forcing the two heavy isotopes of hydrogen to combine through compression and heating, producing ignition and self-sustained fusion burn. The NIF construction project began in 1996 and the conventional facility construction is more than $95 \%$ complete. Eighty percent of the large components of the beampath infrastructure have been procured and are either on site or on the way. Installation of this hardware has begun. The NIF Target Chamber has been set in position, vacuum leak-checked and is now ready for beampath infrastructure, utilities and diagnostics hardware. NIF is being designed, built and operated by a team from Lawrence Livermore, Los Alamos and Sandia National Laboratories and the University of Rochester. NIF construction progress is the subject of a web page found at http://www.llnl.gov/nif/construction/index.html.

\section{Unplanned Releases}

There were no unplanned atmospheric releases of radionuclides at the Livermore site or Site 300 in 2000.

\section{Diffuse Source Dose Assessments}

Diffuse, or non-point, sources are difficult to quantify. There are no EPAmandated methods for estimation or measurement, although LLNL did review a second draft of EPA guidance on this topic during 1994. At this time, however, dose calculations associated with this type of source are left to the discretion of the DOE facility. Livermore-site and Site 300 diffuse sources are described separately.

\section{Livermore-Site Diffuse Sources}

The dose calculations from diffuse sources at the Livermore site in 2000 required three different modeling approaches. Building 331 Yard and Building 612 Yard emissions estimates are based on facility personnel knowledge and environmental surveillance data to estimate emissions. Building 292 required vegetation monitoring and CAP88-PC modeling techniques. Building 514 and the emissions estimates for waste accumulation areas required radiological usage inventory data and CAP88-PC modeling techniques. Data from radiological 
measurements were used as the basis for dose estimates for the Southeast Quadrant and Building 223 soil and gravel cleanup.

\section{Building 292}

Elevated tritium concentrations in soil moisture near Building 292 resulted from a historic leak in an underground retention tank. This contamination has resulted in diffuse tritium emissions due to transpiration from vegetation. In 2000, quarterly samples of the pine tree, which had previously been identified as the primary source of transpired tritium, were used to estimate the emission of tritium from this source. The maximum concentration of tritium in the tissue water of the pine tree was $6460 \mathrm{pCi} / \mathrm{L}$ (239 Bq/L) in 2000. Assuming the tree has an area of $86 \mathrm{~m}^{2}$ and a transpiration rate of $206 \mathrm{~L} / \mathrm{m}^{2} / \mathrm{d}$, the resulting emission rate from this source is $4.9 \times 10^{-4} \mathrm{Ci} / \mathrm{y}\left(1.8 \times 10^{7} \mathrm{~Bq} / \mathrm{y}\right)$. This estimated emission compares well with previous estimates, which ranged from $4.8 \times 10^{-4} \mathrm{Ci} / \mathrm{y}(1.8 \times$ $\left.10^{7} \mathrm{~Bq} / \mathrm{y}\right)$ to $1.4 \times 10^{-3} \mathrm{Ci} / \mathrm{y}\left(5.2 \times 10^{7} \mathrm{~Bq} / \mathrm{y}\right)$ in 1994 through 1999 . The current source term produced a calculated 2000 dose to the SW-MEI from the Building 292 area of $7.2 \times 10^{-8}$ mrem $\left(7.2 \times 10^{-7} \mu \mathrm{Sv}\right)$.

\section{Building 331 Yard}

As the Tritium Facility (Building 331) conducts operations, tritium contaminated equipment and material slated for disposal is removed from the building, packaged in a waste accumulation area, and sent to Hazardous Waste Management Division (HWM) facilities. During 2000, outgassing from such waste contained in a transportainer released approximately $5.2 \mathrm{Ci}\left(1.92 \times 10^{11} \mathrm{~Bq}\right)$ of tritium to the atmosphere outside Building 331. The estimated releases were derived from process and facility knowledge, and environmental surveillance measurements. The estimated release was modeled in CAP88-PC as a $1 \mathrm{~m}^{2}$ area source, leading to a calculated 2000 dose to the SW-MEI of $4.4 \times 10^{-3}$ mrem $(4.4 \times$ $\left.10^{-2} \mu \mathrm{Sv}\right)$; a dose of $3.3 \times 10^{-3}$ mrem $\left(3.3 \times 10^{-2} \mu \mathrm{Sv}\right)$ was calculated when the NEWTRIT model was implemented.

\section{Building 514}

Another potential source of diffuse emissions of a variety of radionuclides was HWM waste storage and treatment operations. Building 514 houses the HWM "tank farm," consisting of six 7,170-liter tanks with ancillary equipment such as pumps, mixers, probes, and a bulking station. The tanks are used to store and treat liquid and solid radioactive and/or mixed wastes. Treatment is performed on a batch basis. Chemicals and waste are added to the tanks to achieve the desired treatment objectives. A 2000 radionuclide usage inventory was conducted for the facility to determine the diffuse source term (Attachment 1). CAP88-PC modeling gave a 2000 EDE for the Tank Farm to the SW-MEI of $9.2 \times 10^{-4}$ mrem $\left(9.2 \times 10^{-3} \mu \mathrm{Sv}\right)$. 


\section{Building 612 Yard}

The Building 612 Yard is a potential source of diffuse emissions of tritium. This area is dedicated to hazardous waste, radioactive waste, and mixed waste management activities. The yard consists of several areas where waste containers are stacked outdoors. Several of these containers are not airtight and outgas tritium. A surveillance air monitor has been placed in the Building 612 Yard to provide continuous measurements of tritium in air near this source. The median annual concentration of tritium in air for 2000 in this area was 54 $\mathrm{pCi} / \mathrm{m}^{3}\left(2.0 \mathrm{~Bq} / \mathrm{m}^{3}\right)$. These data were used to calculate the total tritium emissions from the area, using a conservative approach that assumed the source to be $60 \mathrm{~m}$ south-southwest of the air sampler. With this assumption, a diffuse source emission of $3.6 \mathrm{Ci} / \mathrm{y}\left(1.33 \times 10^{11} \mathrm{~Bq} / \mathrm{y}\right)$ was required to produce the concentrations measured at the air sampler. This source term produced a calculated 2000 dose to the SW-MEI from the Building 612 Yard of $1.5 \times 10^{-2} \mathrm{mrem}\left(1.5 \times 10^{-1} \mu \mathrm{Sv}\right)$ as calculated with CAP88-PC ; a dose of $1.1 \times 10^{-2}$ mrem $\left(1.1 \times 10^{-1} \mu \mathrm{Sv}\right)$ was calculated when the NEWTRIT model was implemented.

\section{Waste Accumulation Area Drum Sampling}

Waste Accumulations Areas (WAAs) are maintained by the LLNL programs as storage areas for waste prior to the transfer of the waste to Hazardous Waste Management. Before the wastes are transferred, Hazardous Waste Management samples the waste drums. Because this sampling represents a potential for exposure to the atmosphere, estimates of the potential dose from this activity are provided. The waste areas are maintained at various locations around the LLNL Livermore Site, so the potential emissions were modeled from the center of the site. The source produced a calculated 2000 dose to the SW-MEI of $8.5 \times 10^{-9}$ mrem $\left(8.5 \times 10^{-8} \mu \mathrm{Sv}\right)$.

\section{Southeast Quadrant}

The Southeast Quadrant of the Livermore site has elevated levels of plutonium in the surface soil (from historic waste management operations) and air (from resuspension). A high volume air particulate sampler is located adjacent to the UNCLE Credit Union (the location of the SW-MEI) to monitor the plutonium levels in this area. Monitoring data from this air sampler were used as a direct measurement of potential dose via the air pathway. The median annual concentration of $239+240 \mathrm{Pu}$ (the analytical technique used, alpha spectroscopy, does not distinguish between ${ }^{239} \mathrm{Pu}$ and ${ }^{240} \mathrm{Pu}$ ) in air of $1.7 \times 10^{-19} \mu \mathrm{Ci} / \mathrm{mL}$ $\left(6.3 \times 10^{-15} \mathrm{~Bq} / \mathrm{mL}\right)$, the dose conversion factor of $3.08 \times 10^{5} \mathrm{mrem} / \mu \mathrm{Ci}$ $\left(8.32 \times 10^{-5} \mathrm{~Sv} / \mathrm{Bq}\right)$ from Federal Guidance Report No. 11, EPA-520/1-88-020, U.S. Environmental Protection Agency (1988) for ${ }^{239} \mathrm{Pu}$ and ${ }^{240} \mathrm{Pu}$, and the standard 
man breathing rates of $8400 \mathrm{~m}^{3} / \mathrm{y}$ were used to calculate the estimated EDE of $4.5 \times 10^{-4}$ mrem $\left(4.5 \times 10^{-3} \mu \mathrm{Sv}\right)$ for 2000 .

\section{Building 223 Soil and Gravel Cleanup}

In 1999, Building 223 Annex was demolished. In 2000, as a final step in the decontamination and decommissioning process for the building, the soil and gravel near the building were analyzed for radionuclides. The resuspension of particles associated with removal of this soil and gravel is a potential diffuse source of radionuclide emissions. The emissions were estimated from measurements of samples of soil and gravel. The estimated release is $1.2 \times 10^{-10}$ $\mathrm{Ci}(4.4 \mathrm{~Bq})^{241} \mathrm{Am} ; 1.6 \times 10^{-12} \mathrm{Ci}\left(5.9 \times 10^{-2} \mathrm{~Bq}\right){ }^{243} \mathrm{Am}$; and $2.6 \times 10^{-10} \mathrm{Ci}(9.6 \mathrm{~Bq})$ ${ }^{239} \mathrm{Pu}$. The CAP88-PC estimated dose to the SW-MEI is $1.2 \times 10^{-7} \mathrm{mrem}$ $\left(1.2 \times 10^{-6} \mu \mathrm{Sv}\right)$.

\section{Site 300 Diffuse Sources}

Diffuse sources at Site 300 involve tritium and uranium. During remediation efforts at Site 300, LLNL completed a contaminant screening to identify potential routes of migration from soil to air and other environmental media of these radionuclides and other contaminants (Final Site Wide Remedial Investigation Report; Webster-Scholten, Ed., 1994, Lawrence Livermore National Laboratory, Livermore, CA, UCRL-AR-108131). Tritium and ${ }^{238} \mathrm{U}$ were identified as contaminants of potential concern.

\section{Tritium Evaporation and Migration at Site 300}

Tritium gas and solids containing tritium $\left(\mathrm{Li}^{3} \mathrm{H}\right)$ were components of explosives assemblies tested on the firing tables during past experiments. Most of the gaseous tritium escaped to the atmosphere during the tests, but some of the solid $\mathrm{Li}^{3} \mathrm{H}$ remained as residue in the firing table gravel. Rainwater and dust-control rinse water percolated through the gravel, causing the tritium to migrate into the subsurface soil and, in some cases, eventually to the ground water. Tritium contaminated gravel was removed from the firing tables in 1988 and disposed in the Pit 7 landfill. Tritium in landfills, firing table soils, and ground water are potential sources of diffuse emissions of tritium to the atmosphere at Site 300. LLNL personnel maintain an air tritium sampler at a perimeter location at Site 300, and doses from diffuse tritium sources may be estimated based on the monitoring data for that sampling location. For the calendar year 2000, all measurements at the Site 300 perimeter location were below the detection limits of the analytical method. These measurements are consistent with natural background measurements, and, therefore, no contribution to dose from diffuse sources of tritium for Site 300 were calculated for the year. 


\section{Resuspension of Depleted Uranium at Site 300}

Like tritium, depleted uranium has been used as a component of explosives test assemblies. It remains as a residue in surface soils, especially near the firing tables. Because surface soil is subject to resuspension by the action of wind, rain, and other environmental disturbances, the collective effects of surface soil uranium residuals on off-site doses were evaluated.

For the 1995 NESHAPs annual report, we developed calculations to separate the contribution to measured uranium activities from naturally occurring uranium (NU) (Gallegos et al., 1996, Lawrence Livermore National Laboratory, UCRL-ID113867-96). We base our dose estimate for resuspended depleted uranium (DU) on the measured environmental surveillance monitoring total concentration in air of uranium-238, subtracting out the part contributed by NU, from the following equation:

$$
\mu=\frac{0.00726-0.99274 \frac{M(C U-235)}{M(C U-238)}}{0.00526 \frac{M(C U-235)}{M(C U-238)}+0.00526},
$$

where $\mu$ is the fraction (by weight) of uranium contributed by operations, CU is composite uranium (both DU and NU), M(CU-235) the mass of U-235 in the composite (measured) uranium, and $\mathrm{M}(\mathrm{CU}-238)$ the mass of U-238 in the composite (measured) uranium. (For derivation of the equation see the 1995 NESHAPs annual report, referenced above.) For 2000, we compared the concentrations of all locations at Site 300 and used the overall median of measurements collected from eight air samplers at Site 300 (i.e., $\mathrm{M}(\mathrm{CU}-238)$ equal to $1.8 \times 10^{-11} \mathrm{~g} / \mathrm{m}^{3}$ and $\mathrm{M}(\mathrm{CU}-235)$ equal to $0.8 \times 10^{-13} \mathrm{~g} / \mathrm{m}^{3}$; see Biermann et al., 2001, Environmental Report 2000, Lawrence Livermore National Laboratory, UCRL-50027-00, in preparation) to represent the potential annual exposure from resuspension of DU at Site 300.

Using these calculations to apportion the $\mathrm{M}(\mathrm{CU})$ for 2000 , we obtain an annual average concentration of DU in air from resuspension of $1.8 \times 10^{-11} \mathrm{~g} / \mathrm{m}^{3}$. Using the fractions $0.998,0.002$, and 0.000005 to represent the amounts of $238 \mathrm{U}, 235 \mathrm{U}$, and ${ }^{234} \mathrm{U}$; specific activities of $3.33 \times 10^{-7}, 2.14 \times 10^{-6}$, and $6.20 \times 10^{-3} \mathrm{Ci} / \mathrm{g}$ for ${ }^{238} \mathrm{U},{ }^{235} \mathrm{U}$, and ${ }^{234} \mathrm{U}$; a yearly inhalation rate of $8400 \mathrm{~m}^{3} / \mathrm{y}$, and dose conversion factors from EPA Regulatory Guide 11 of $1.18 \times 10^{11}, 1.23 \times 10^{11}$, and $1.32 \times 10^{11} \mathrm{mrem} / \mathrm{Ci}$; we obtain a total dose for resuspended DU of $3.7 \times 10^{-3}$ mrem $\left(3.7 \times 10^{-2} \mu \mathrm{Sv}\right)$. 


\section{Total Dose Estimate and Comparison with Previous Years' Data}

For the Livermore site, the dose calculated for the SW-MEI from diffuse emissions in 2000 totaled 0.021 mrem $(0.21 \mu \mathrm{Sv})$. The dose due to point sources was 0.017 mrem $(0.17 \mu \mathrm{Sv})$. When combined, the total annual dose was 0.038 mrem $(0.38 \mu \mathrm{Sv})$. The dose from point sources includes Tritium Facility HT emissions modeled as HTO, as directed by EPA Region IX. EPA Region IX acknowledges that such modeling results in a very conservative overestimation of the dose. The dose calculated using NEWTRIT from both point and diffuse source emissions from the Livermore site is 0.033 mrem $(0.33 \mu \mathrm{Sv})$.

The total dose to the Site 300 SW-MEI from operations in 2000 was 0.019 mrem $(0.19 \mu \mathrm{Sv})$. Point source emissions from firing table explosives experiments accounted for 0.015 mrem $(0.15 \mu \mathrm{Sv})$, of this total, while 0.0037 mrem $(0.037 \mu \mathrm{Sv})$, or about $21 \%$, was contributed by diffuse sources. Table 5 presents the facilities or sources that account for $90 \%$ or more of the doses for the Livermore site or Site 300 SW-MEI.

Comparison of the 2000 total dose estimate with that of previous years can be made by reviewing the information presented in Table 6. No diffuse emissions were reported at Site 300 for years before 1993, so comparison for total dose can only be made with the values for 1993 and later; in addition, diffuse source doses were not reported separately from the total dose for the Livermore site for 1990 and 1991.

Table 5. List of facilities or sources whose emissions account for $90 \%$ or more of the doses for the Livermore site and Site 300 SW-MEI. Where different, doses for the NEWTRIT model are supplied.

\begin{tabular}{|c|c|c|c|c|}
\hline Facility or Source & CAP88-PC & $\begin{array}{l}\text { mrem } \\
\text { NEWTRIT } \\
\text { in } \\
\text { CAP88-PC }\end{array}$ & $\begin{array}{r}\text { Percent C } \\
\text { to Tot }\end{array}$ & $\begin{array}{l}\text { ontribution } \\
\text { al Dose } \\
\text { NEWTRIT } \\
\text { in } \\
\text { CAP88-PC }\end{array}$ \\
\hline \multicolumn{5}{|l|}{ Livermore site } \\
\hline Building 612 Yard (diffuse source) & 0.015 & 0.011 & $40 \%$ & $38 \%$ \\
\hline Building 331 (point source) & 0.0095 & 0.0063 & $25 \%$ & $22 \%$ \\
\hline Building 514 Evaporator (point source) & 0.0060 & & $16 \%$ & $20 \%$ \\
\hline Building 331 Area Source (diffuse source) & 0.0044 & 0.0033 & $12 \%$ & $11 \%$ \\
\hline \multicolumn{5}{|l|}{ Site 300} \\
\hline Building 851 Firing Table (point source) & 0.015 & & $79 \%$ & \\
\hline Soil resuspension (diffuse source) & 0.0037 & & $21 \%$ & \\
\hline
\end{tabular}


LLNL NESHAPs Report 2000

Table 6. Doses (in mrem) calculated for the Site-Wide Maximally Exposed Individual for the Livermore site and Site 300, 1990 to 2000.

\begin{tabular}{cccc}
\hline Year & Total Dose & Point Source Dose & Diffuse Source Dose \\
\hline Livermore site & & & \\
2000 & $0.038^{\mathrm{a}}$ & $0.017^{\mathrm{a}}$ & 0.021 \\
1999 & $0.12^{\mathrm{a}}$ & $0.094^{\mathrm{a}}$ & 0.028 \\
1998 & $0.055^{\mathrm{a}}$ & $0.031^{\mathrm{a}}$ & 0.024 \\
1997 & 0.097 & 0.078 & 0.019 \\
1996 & 0.093 & 0.048 & 0.045 \\
1995 & 0.041 & 0.019 & 0.022 \\
1994 & 0.065 & 0.042 & 0.023 \\
1993 & 0.066 & 0.040 & 0.026 \\
1992 & 0.079 & 0.069 & 0.010 \\
1991 & 0.234 & $-\mathrm{b}$ & $-\mathrm{b}$ \\
1990 & 0.240 & $-\mathrm{b}$ & $-\mathrm{b}$ \\
Site 300 & & & \\
2000 & & 0.015 & 0.0037 \\
1999 & 0.019 & 0.034 & 0.0012 \\
1998 & 0.035 & 0.019 & 0.005 \\
1997 & 0.024 & 0.011 & 0.0088 \\
1996 & 0.020 & 0.033 & 0.00045 \\
1995 & 0.033 & 0.020 & 0.003 \\
1994 & 0.023 & 0.049 & 0.032 \\
1993 & 0.081 & 0.011 & 0.026 \\
1992 & 0.037 & 0.021 & $-\mathrm{c}$ \\
1991 & 0.021 & 0.044 & $-\mathrm{c}$ \\
1990 & 0.044 & 0.057 & $-\mathrm{c}$ \\
\hline
\end{tabular}

a The dose includes HT emissions modeled as HTO as directed by EPA Region IX. EPA Region IX acknowledges that such modeling results in a very conservative overestimation of the dose. This methodology is used for purposes of compliance.

b Diffuse source doses were not reported separately from the total dose for the Livermore site for 1990 and 1991.

c No diffuse emissions were reported at Site 300 for years before 1993. 


\section{SECTION V. Certification}

I certify under penalty of law that I have personally examined and am familiar with the information submitted herein, and based on my inquiry of those individuals immediately responsible for obtaining the information, I believe that the submitted information is true, accurate, and complete. I am aware that there are significant penalties for submitting false information, including the possibility of fine and imprisonment.

Name: Phillip Hill

Director, Livermore Safety Oversight Division

U.S. Department of Energy

Livermore Site Office

7000 East Avenue, L-293

Livermore, CA $9455 \rho$

Signature:

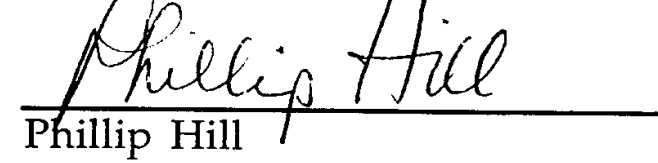

Date: $6-20-01$

I certify under penalty of law that this document and all attachments were prepared under my direction or supervision in accordance with a system designed to assure that qualified personnel properly gather and evaluate the information submitted. Based on my inquiry of the person or persons who manage the system, or those persons directly responsible for gathering the information, the information submitted is, to the best of my knowledge and belief, true, accurate, and complete. I am aware that there are significant penalties for submitting false information, including the possibility of fine and imprisonment for knowing violations.

Name: $\quad$ Dennis K. Fisher

Associate Director

Safety, Security, and Environmental Protection

Lawrence Livermore National Laboratory

7000 East Avenue, L-668

Livermore, CA 94550

Signature:

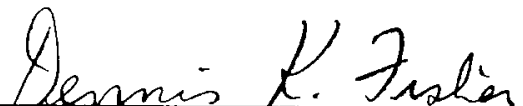

Dennis K. Fisher

Date: $6 / 20 / 01$ 


\section{SECTION VI. Supplemental Information}

\section{Collective Effective Dose Equivalent}

Population doses, or collective EDEs, for both LLNL sites were calculated out to a distance of $80 \mathrm{~km}$ in all directions from the site centers using CAP88-PC. As noted earlier, CAP88-PC evaluates the four principal exposure pathways: ingestion through food and water consumption, inhalation, air immersion, and irradiation by contaminated ground surface.

For the 2000 modeling effort, we constructed updated population distributions centered on the two LLNL sites. These population distributions are based on the LandScan Global Population 1998 Database (Dobson, J. E., E. A. Bright, P. R. Coleman, R.C. Durfee, B. A. Worley, LandScan: A Global Population Database for Estimating Populations at Risk, Photogrammetric Engineering \& Remote Sensing Vol. 66, No. 7, July 2000, pp. 849-857). The population distributions were developed using the geographic information system software, ArcView@, to construct five equidistant radial sectors in each of the 16 wind directions required by CAP88-PC. The population for each sector segment was determined by running code developed in the LandScan project and distributed with the LandScan Database. Key population centers affected by LLNL emissions are the relatively nearby communities of Livermore and Tracy, and the more distant metropolitan areas of Oakland, San Francisco, and San Jose, as well as the San Joaquin Valley communities of Modesto and Stockton. Within the $80 \mathrm{~km}$ outer distance specified by DOE, there are 6.9 million residents included for the Livermore site collective dose determination, and 6.0 million for Site 300. Our updated population data files (distribution of population with distance and direction) are shown in Tables 7 and 8 for the Livermore site and Site 300.

For the evaluation of the population dose, as distinct from the individual dose, all food (and in particular milk) was assumed to be produced locally. This decision was made because, although there are no commercial dairy animals within the distances used to evaluate individual doses, many dairy animals live within $80 \mathrm{~km}$ of the Livermore site and Site 300 .

The collective EDE, which is the sum of the individual doses to all 6.9 million people within $80 \mathrm{~km}$ of the Livermore site, due to 2000 Livermore-site operations was 0.52 person-rem (0.0052 person-Sv). The collective dose includes HT emissions conservatively modeled as HTO as directed by EPA Region IX. This methodology is used for purposes of compliance. When the NEWTRIT model is used for sources with significant tritium emissions the collective EDE for Livermore-site operations is 0.64 person-rem (0.0064 person-Sv). 
LLNL NESHAPs Report 2000

Table 7. Population distribution for LLNL's Livermore site, based on LandScan Global Population 1998 Database. Values are population in sector segments bounded by the indicated inner and outer radii, for sixteen $22.5^{\circ}$-sector directions.

\begin{tabular}{|c|c|c|c|c|c|c|}
\hline \multirow[b]{2}{*}{ Direction } & \multicolumn{5}{|c|}{ Range of distance from site $(\mathrm{km})$} & \multirow[b]{2}{*}{ Total } \\
\hline & $0-16$ & $16-32$ & $32-48$ & $48-64$ & $64-80$ & \\
\hline $\mathrm{N}$ & 1450 & 13875 & 40582 & 3883 & 2008 & 61798 \\
\hline NNW & 2402 & 598 & 129026 & 651 & 188656 & 321333 \\
\hline NW & 7204 & 10769 & 286962 & 124688 & 114965 & 544588 \\
\hline WNW & 8883 & 87666 & 243826 & 513228 & 186746 & 1040349 \\
\hline W & 50867 & 84307 & 340602 & 381509 & 638099 & 1495384 \\
\hline WSW & 19794 & 130284 & 130721 & 345940 & 14858 & 641597 \\
\hline SW & 211 & 90969 & 264027 & 146358 & 5380 & 506945 \\
\hline SSW & 37 & 21820 & 637423 & 377440 & 54034 & 1090754 \\
\hline S & 30 & 31 & 50543 & 71473 & 57947 & 180024 \\
\hline SSE & 18 & 8 & 21 & 63 & 2551 & 2661 \\
\hline SE & 33 & 282 & 299 & 50 & 7358 & 8022 \\
\hline ESE & 75 & 696 & 1043 & 15304 & 67847 & 84965 \\
\hline E & 102 & 10957 & 4646 & 177316 & 171738 & 364759 \\
\hline ENE & 119 & 37862 & 68559 & 15991 & 4465 & 126996 \\
\hline $\mathrm{NE}$ & 210 & 354 & 116801 & 251565 & 17687 & 386617 \\
\hline NNE & 591 & 7568 & 878 & 5856 & 18509 & 33402 \\
\hline Total & 92026 & 498046 & 2315959 & 2431315 & 1552848 & 6890194 \\
\hline
\end{tabular}

Table 8. Population distribution for LLNL's Site 300, based on LandScan Global Population 1998 Database. Values are population in sector segments bounded by the indicated inner and outer radii, for sixteen $22.5^{\circ}$-sector directions.

\begin{tabular}{|c|c|c|c|c|c|c|}
\hline \multirow[b]{2}{*}{ Direction } & \multicolumn{5}{|c|}{ Range of distance from site $(\mathrm{km})$} & \multirow[b]{2}{*}{ Total } \\
\hline & $0-16$ & $16-32$ & $32-48$ & $48-64$ & $64-80$ & \\
\hline $\mathrm{N}$ & 220 & 3538 & 1073 & 2898 & 4005 & 11734 \\
\hline NNW & 53 & 3966 & 90277 & 4798 & 42837 & 141931 \\
\hline NW & 122 & 572 & 22811 & 287027 & 123361 & 433893 \\
\hline WNW & 869 & 30890 & 103096 & 356675 & 622160 & 1113690 \\
\hline W & 72 & 70166 & 192303 & 312252 & 563080 & 1137873 \\
\hline WSW & 22 & 549 & 214821 & 291111 & 153194 & 659697 \\
\hline SW & 9 & 71 & 393240 & 686995 & 23322 & 1103637 \\
\hline SSW & 50 & 7 & 87986 & 189996 & 24362 & 302401 \\
\hline S & 127 & 21 & 13 & 21879 & 47396 & 69436 \\
\hline SSE & 220 & 248 & 11 & 40 & 122 & 641 \\
\hline SE & 142 & 154 & 329 & 9041 & 3206 & 12872 \\
\hline ESE & 267 & 858 & 14710 & 55929 & 36513 & 108277 \\
\hline E & 450 & 2096 & 138230 & 175983 & 4064 & 320823 \\
\hline ENE & 4049 & 21315 & 41196 & 28864 & 2570 & 97994 \\
\hline $\mathrm{NE}$ & 38313 & 12206 & 97157 & 7153 & 5334 & 160163 \\
\hline NNE & 2734 & 964 & 221368 & 84029 & 22727 & 331822 \\
\hline Total & 47719 & 147621 & 1618621 & 2514670 & 1678253 & 6006884 \\
\hline
\end{tabular}


The collective dose is less than the 1999 value of 1.7 person-rem $(0.017$ personSv) because the stack releases from Building 331 (the Tritium Facility) decreased in 2000. This collective EDE can also be compared to the collective dose from natural background radioactivity for 6.9 million people of $2.06 \times 10^{6}$ person-rem (2.06 $\times 10^{4}$ person-Sv).

The corresponding collective EDE from Site 300 operations in 2000, 2.5 personrem (0.025 person-Sv), was due to point source emissions. The total collective EDE value for Site 300 is the less than the 11 person-rem ( 0.11 person-Sv) for 1999 , primarily as the result of a reduced number of test shots that involved the use of radioactive material.

The larger collective dose for Site 300 compared to the Livermore site is traceable primarily to the highly conservative assumptions about the Site 300 explosives experiments, especially regarding the fraction of radioactive material that is aerosolized and the height and trajectory of the explosive debris cloud. This conservative modeling methodology over predicts the quantity of radionuclides released to air by at least a factor of five, we believe, and over estimates the long range dispersal of material in these experiments. In 1992, we submitted to EPA a modeling protocol designed to treat the transient explosive experiments more realistically than does CAP88-PC, but this protocol was not accepted.

\section{Compliance with 40 CFR 61 Subpart H (61.93)}

Calculations of effective dose equivalents for all Livermore-site and Site 300 facilities having the potential to release radionuclides to the atmosphere have been completed. Annual doses from actual total emissions of all facilities during 2000 were found to be well below the 10 mrem $(100 \mu \mathrm{Sv})$ NESHAPs dose standard. Tritium accounted for more than half of the Livermore-site calculated dose, while at Site 300 practically the entire calculated dose was due to the isotopes ${ }^{238} \mathrm{U},{ }^{235} \mathrm{U}$, and ${ }^{234} \mathrm{U}$, in depleted uranium.

The need for stack monitoring is based on evaluations of potential emissions without control devices or on EPA concurrence for those facilities for which classification or other issues prevent a usage inventory based evaluation. Facilities in the latter category include Building 331, Building 332, and the seismically hardened area of Building 251.

Several other Livermore-site facilities (Buildings 175, 251 unhardened, and 491) also will maintain continuous monitoring systems; however, calculations using unabated potential emissions resulted in EDEs of less than $0.1 \mathrm{mrem} / \mathrm{y}(1 \mu \mathrm{Sv} / \mathrm{y})$ 
for the emissions from each of these facilities. Although this monitoring will be continued, it is not required under NESHAPs.

For facilities having discharge points without continuous monitoring, the requirement for continuous monitoring was individually evaluated. The evaluation was based on unabated emissions, even if emission control systems existed. Although many operations were evaluated in 2000, none required new sampling systems.

\section{Status of compliance with 40 CFR 61 Subpart Q - National Emission Standards for Radon Emissions from Department of Energy Facilities}

LLNL does not have storage and disposal facilities for radium containing materials that would be a significant source of radon.

\section{Status of compliance with 40 CFR 61 Subpart T - National Emission Standards for Radon Emissions from the Disposal of Uranium Mill Tailings}

LLNL does not have or store any uranium mill tailings.

\section{Information on Radon-220 and Radon-222 Emissions}

Radon emissions occur naturally by emanation from the earth. Radon-222 emissions that were reported in past NESHAPs annual reports from research experiments at the Livermore site did not occur in 2000.

\section{Air Monitoring}

In this section we describe air effluent continuous sampling systems at LLNL facilities, periodic confirmatory measurements made in 2000 of emissions from sources not required to have continuous monitoring, and surveillance monitoring.

\section{Continuous Monitoring}

In 2000, there were six buildings (Buildings 175, 177, 251, 331, 332, and 491) at the LLNL site that had radionuclide air effluent monitoring systems. These buildings are listed in Table 9, along with the number of samplers, the types of samplers, and the analytes of interest. Many would operate from emergency power systems if normal power were lost. 
Table 9. Air effluent sampling locations and systems.

\begin{tabular}{|c|c|c|c|c|}
\hline Building & Facility & Analytes & $\begin{array}{l}\text { Sample } \\
\text { type }\end{array}$ & $\begin{array}{l}\text { Number of } \\
\text { samplers }\end{array}$ \\
\hline 175 & MARS a & Gross $\alpha, \beta$ on particles & Filter & 6 \\
\hline 177 & Extractor Test ${ }^{a}$ & Gross $\alpha, \beta$ on particles & Filter & 1 \\
\hline \multirow[t]{3}{*}{251} & Heavy Elements & & & \\
\hline & Unhardened area & Gross $\alpha, \beta$ on particles & Filters & 28 \\
\hline & Hardened area & Gross $\alpha, \beta$ on particles & Filters & 4 \\
\hline \multirow[t]{2}{*}{331} & Tritium & Tritium & $\begin{array}{l}\text { Ionization } \\
\text { Chamberb }\end{array}$ & 4 \\
\hline & & $\begin{array}{l}\text { Gaseous tritium/ } \\
\text { tritiated water vapor }\end{array}$ & Molecular sieves & 4 \\
\hline \multirow[t]{2}{*}{332} & Plutonium & Gross $\alpha, \beta$ on particles & $\mathrm{CAM}^{\mathrm{b}}$ & 12 \\
\hline & & Gross $\alpha, \beta$ on particles & Filters & 16 \\
\hline 491 & Isotope Separation ${ }^{\mathrm{a}}$ & Gross $\alpha, \beta$ on particles & Filters & 1 \\
\hline
\end{tabular}

Note: "CAM" denotes Eberline continuous air monitors.

a Operations discontinued, however, air effluent sampling systems at this building continue to operate as part of the maintenance and surveillance shutdown plan for AVLIS facilities

b Alarmed systems.

Air samples for particulate emissions are extracted downstream of HEPA filters and prior to the discharge point to the atmosphere. Particles are collected on membrane filters. The sample filters are removed and analyzed for gross alpha and beta activity on a weekly or bi-weekly frequency depending on the facility. In most cases, simple filter type aerosol collection systems are used. However, in some facilities, alpha continuous air monitors (CAMs) are used for sampling. In addition to collecting a sample of particles, the CAM units provide an alarm capability for the facility in the event of a release of alpha activity.

Detection of gross alpha and beta activity resulting from particles collected on the air filters is accomplished using gas flow proportional counters. Analysis is delayed for at least four days from the end of sample collection to allow for the decay of naturally occurring radon daughters. For verification of the operation of the counting system, calibration sources, as well as background samples, are intermixed with the sample filters for analysis. Analysis is performed by the Radiological Measurements Laboratory (RML) in the Hazards Control Department (HCD).

Each stack of the Tritium Facility (Building 331) is monitored for tritium release by both a continuous monitoring alarm system and continuous molecular sieve 
samplers. The alarmed samplers, Overhoff ion chambers, provide real time tritium concentration release levels (HT and HTO). The sieve samplers, which can discriminate between tritiated water (HTO) vapor and molecular tritium $(\mathrm{HT})$, provide the values used for environmental reporting and are exchanged weekly. Each sieve sampler (not alarmed) is in parallel with an alarmed monitor and consists of two molecular sieves. The first sieve collects tritiated water vapor; the second sieve contains a palladium coated catalyst that converts molecular tritium to tritiated water, which is then collected. The molecular sieve samples are submitted to the Hazards Control Analytical Laboratory where they are installed into a recovery system for the bake out of tritiated water vapor and subsequent condensation and collection of the water. The retrieved tritiated water is analyzed by RML using liquid scintillation counting techniques.

Data from air particulate sampling filter and molecular sieve analyses are reviewed by Hazards Control Department Health Physicists responsible for each facility and an Environmental Protection Department Environmental Analyst.

\section{Periodic Confirmatory Sampling}

Results of NESHAPs periodic confirmatory sampling serve to confirm two objectives: 1) that those operations not continuously monitored, in fact, do not need to be continuously monitored, and 2) that radionuclide usage inventory based estimates of emissions and their corresponding doses are conservative. In 2000, such sampling was performed at Building 625. The sampling results are discussed below. None of the estimated emissions contribute significantly to the dose for the Livermore site SW-MEI. None of the operations require continuous sampling.

Periodic confirmatory sampling was conducted for a 3-day period from Building 625. The HEPA filtered exhaust ventilates a tent where repackaging of waste occurs. One filter sample for particulate emissions was taken while HEPA filters were dismantled and repackaged. The filter sample, Millipore AW-19, 47-mm diameter media, was analyzed for gross alpha and gross beta activity. All measured activity concentrations were less than the minimum detectable concentrations of $6.8 \times 10^{-16} \mathrm{Ci} / \mathrm{m}^{3}\left(2.5 \times 10^{-5} \mathrm{~Bq} / \mathrm{m}^{3}\right)$ and $1.7 \times 10^{-15} \mathrm{Ci} / \mathrm{m}^{3}$ $\left(6.3 \times 10^{-5} \mathrm{~Bq} / \mathrm{m}^{3}\right)$ for alpha and beta activity, respectively. Projecting the results to occur for 8 hours per day and 5 days per week for the entire year yields potential emissions of less than $1.8 \times 10^{-9} \mathrm{Ci}\left(6.7 \times 10^{1} \mathrm{~Bq}\right)$ alpha activity and less than $4.6 \times 10^{-9} \mathrm{Ci}\left(1.7 \times 10^{2} \mathrm{~Bq}\right)$ beta activity. CAP88-PC modeling indicates the dose from these emissions to be less than $5.4 \times 10^{-6}$ mrem $\left(5.4 \times 10^{-5} \mu \mathrm{Sv}\right)$, or about $0.01 \%$ of the EDE from all Livermore site operations for 2000. Because the dose calculated is estimated from a minimum detectable emission rather than an actual measured emission, it represents an upper bound dose estimate, and is 
consistent with the dose based on the inventory approach and reported in Attachment 1.

\section{General Surveillance Monitoring}

Surveillance air monitoring for tritium and radioactive particles has been in place since the 1970s and will continue. LLNL currently maintains seven continuously operating, high volume, air particulate samplers on the Livermore site, nine in the Livermore Valley, eight at Site 300, and one in Tracy. LLNL also maintains eleven continuously operating tritiated water vapor samplers on the Livermore site, six samplers in the Livermore Valley and one offsite near Site 300. The samplers are positioned to ensure reasonable probability that any significant airborne concentration of particulate and tritiated water vapor effluents resulting from LLNL operations will be detected. Many of the surveillance air monitors are placed near diffuse emission sources, such as those near Buildings 292, 331, 514, and 612, as well as in and around the Southeast Quadrant of the Livermore site. As such, their results can be used to estimate and/or confirm the emissions from the associated diffuse sources. Also included are air particulate and tritiated water vapor monitors positioned at the location of the SW-MEI for the Livermore site. Results from the latter samplers provide a source term for large area diffuse sources and also serve to confirm the SW-MEI EDEs as determined from facility emissions using air effluent monitoring results and usage inventories.

The data from the air surveillance monitoring network provide continuous measurements of the concentrations of radionuclides present in the air at the Livermore site, Site 300, and in the surrounding areas. Data from the network are presented in the LLNL Environmental Report, which is prepared annually and available to the public. (Biermann et al., Environmental Report for 2000, Lawrence Livermore National Laboratory, Livermore, CA, UCRL-50027-00, to be published in October 2001.)

\section{Comparison of 2000 Modeling Results with Surveillance Monitoring Data}

A comparison was made between CAP88-PC modeling results and surveillance air monitoring data for the eleven tritiated water vapor monitors on the Livermore site (designated VIS, SALV, POOL, CAFE, MESQ, MET, COW, B331, B514, B624, and B292) and one off-site tritiated water vapor monitor (ZON7). Monitor locations are shown in Figure 7.

Only the three most significant sources of tritium releases to air at the Livermore site were included in the model-data comparison. The largest point source is the 


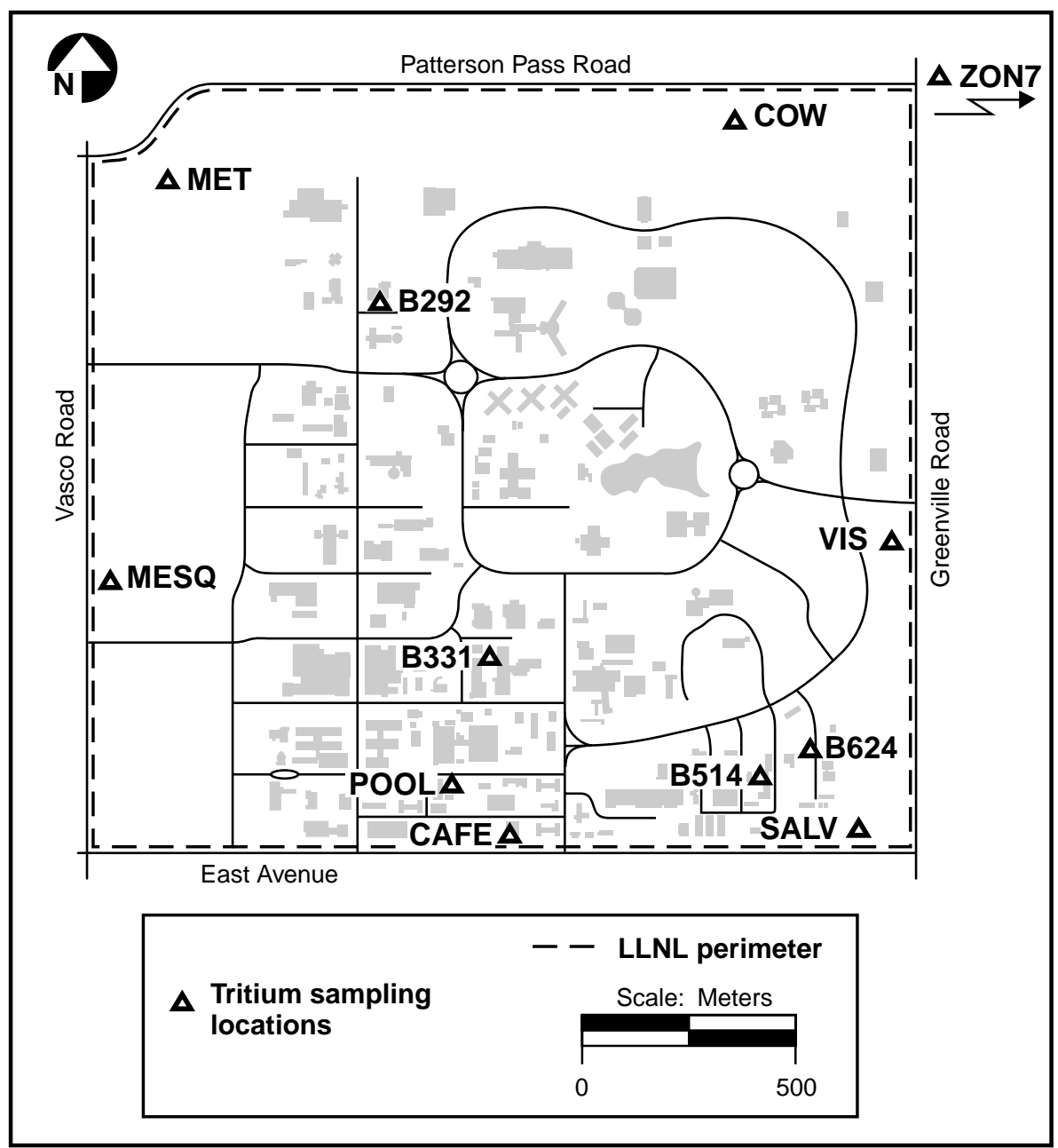

Figure 7. Tritiated water vapor surveillance sampling locations.

Tritium Facility (Building 331), where the tritium is emitted from two 30-mhigh, continuously monitored stacks; a total of $35 \mathrm{Ci}\left(1.3 \times 10^{12} \mathrm{~Bq}\right)$ of HTO was emitted from these stacks in 2000. (The $4.8 \mathrm{Ci}\left[1.8 \times 10^{11} \mathrm{~Bq}\right]$ of HT emitted from the Tritium Facility is not included in the comparison because the surveillance monitors are not designed to measure HT.) The other two principal sources are open air diffuse emission areas associated with the Building 612 yard and the Tritium Facility (Building 331) yard. Emissions from these sources were estimated to be $3.6 \mathrm{Ci}\left(1.3 \times 10^{11} \mathrm{~Bq}\right)$ and $5.2 \mathrm{Ci}\left(1.9 \times 10^{11} \mathrm{~Bq}\right)$ in 2000 . All other potential sources of tritiated water vapor release, such as the hazardous waste management operations in Building 514 and the Building 292 diffuse source were too minor to influence the model-data comparison.

Annual average concentrations of HTO in $\operatorname{air}\left(\mathrm{pCi} / \mathrm{m}^{3}\right)$ at the locations of the twelve monitors were modeled for the three sources individually and 


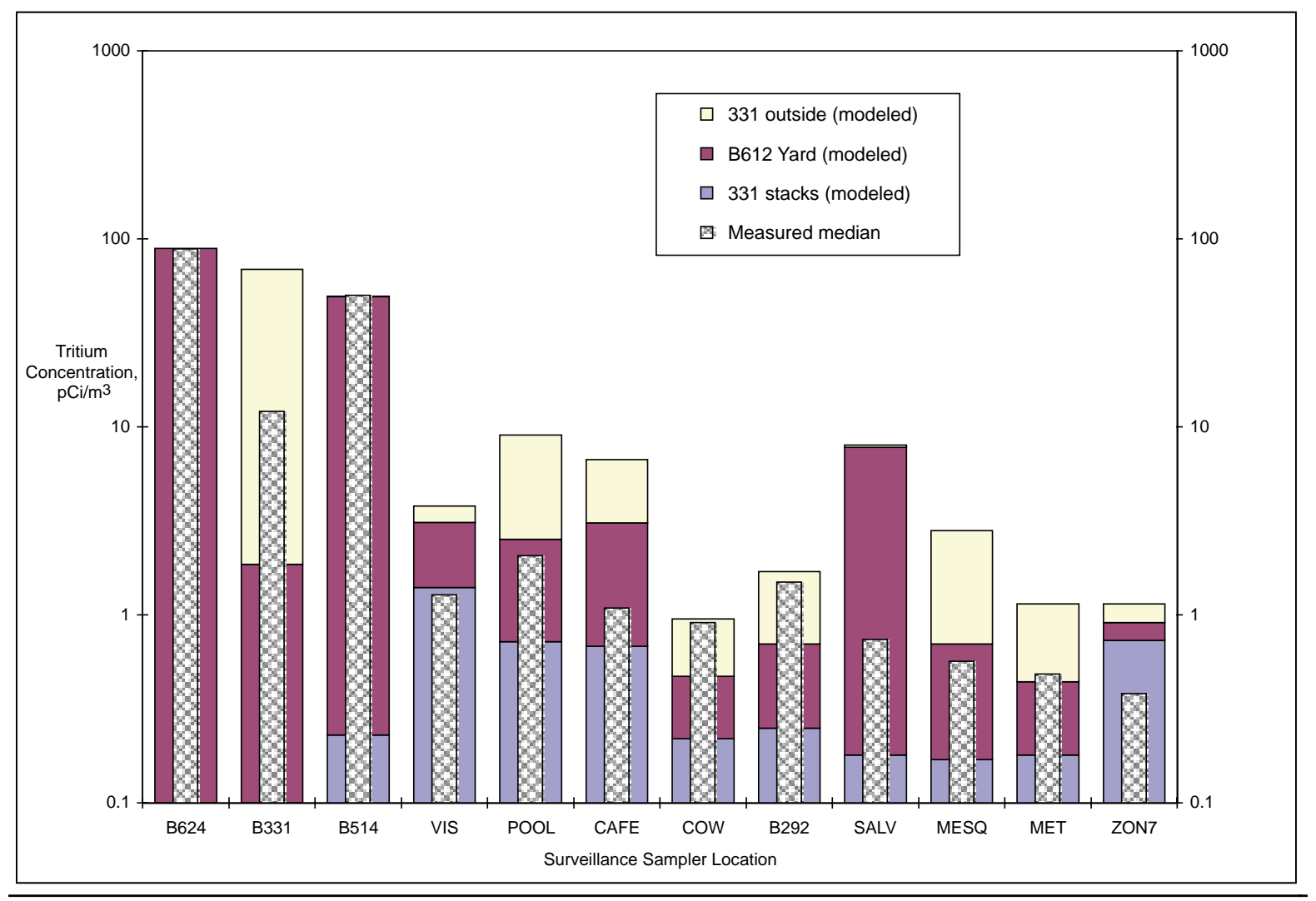

Figure 8. Comparison of measured and modeled tritium concentrations, 2000. Note that the logarithmic scaling used visually distorts the smaller concentration values.

collectively, and compared to the measured annual median concentrations at the twelve monitoring locations. The results are displayed in Figure 8.

The Building 331 stack emissions and estimated emissions from the Building 331 yard area were used as input to CAP88-PC with site specific meteorological data to calculate the annual average concentrations at the desired locations. However, the B612 yard emission rates were not independently measured, but rather were determined from the surveillance tritiated water vapor monitor data for the particular monitor in the closest proximity, by requiring that the modeled concentration match the data from that particular monitor. The source term for Building 612 yard was adjusted to give the observed value at the B624 monitor.

The main conclusion shown in Figure 8 is that by taking into account the three leading sources of tritiated water vapor releases to air-the Building 331 stacks, Building 612 yard, and the Building 331 yard-fairly good agreement is obtained with data for all of the monitors. Generally, the modeling results agree with the 
on-site monitoring data within a factor of 5 (at 9 out of twelve locations). However, in the case of two monitors (B331 and CAFE), the difference is nearly a factor of seven, and at one monitor (SALV) the difference is nearly a factor of eleven, with the model predicting higher concentrations where public exposures could occur. Because the magnitude of the measurements and modeling results are decreasing, the relative differences between the monitoring and modeling results appears to be increasing, as compared to previous years. Nonetheless, the relatively good agreement of monitoring and modeling results in calendar year 2000, when point source emissions were low, is another indication of the robustness and reliability of the CAP88-PC model predictions where terrain effects are minimal, as they are at the Livermore site.

\section{The NESHAPs QA Program}

The LLNL NESHAPs quality assurance program is a multi-organizational effort that is described in the Lawrence Livermore National Laboratory Quality Assurance Project Plan for National Emission Standards for Hazardous Air Pollutants (NESHAPs), 40 CFR 61, Subpart H (QAPP-Hall, L.C. and A.H. Biermann, UCRL-ID-13914, 2000). The QAPP is structured in the manner prescribed for quality assurance programs that is outlined in Appendix B, Method 114 of 40 CFR 61. The QAPP describes the organization structure and functional responsibilities, objectives of the quality assurance program, administrative controls in place for handling sample collection systems, sample collection and effluent flow rate measurement systems, corrective actions, and reporting.

The major components of this multi-organizational effort are the LLNL facilities/programs that have continuous monitoring systems, the Radiological Measurements Laboratory (RML) and the Analytical Laboratory (AL), both in the Hazards control Department (HCD), and the Environmental Protection Department (EPD). In addition to the QAPP, NESHAPs Agreement of Roles and Responsibilities (NARRs) documents are in place between EPD and the facilities and/or programs and HCD; these NARRs formalize responsibilities and obligations of the organizations regarding many tasks for the air effluent sample network. Tasks that are addressed in the NARRs include air sampler design and installation, procedures and their implementation, sampling, sample analysis and tracking, maintenance and repair of sampling systems, guidance on regulatory requirements, documentation of the sampling network, reporting, and the archival of records.

EPD, which is responsible for NESHAPs modeling and reporting, also operates under a Quality Assurance Management Plan and associated procedures and 
guidance documentation. The Terrestrial and Atmospheric Monitoring and Modeling Group (TAMM) of EPD is responsible for modeling and reporting radiological emissions, and potential emissions, for NESHAPs compliance purposes. Detailed records are kept of all measurements, CAP88-PC model runs, and calculations, and selected model runs are validated. The TAMM group is informed of proposed new operations, and modified operations where significant changes in radiological usage inventories occur, by several mechanisms. These mechanisms include the review of National Environmental Policy Act (NEPA) documentation, review of facility specific safety procedures and plan, review of LLNL Integrated Safety Management System documentation, and representation on Environmental Support Teams. All NESHAPs evaluations and calculations, along with supporting information, are archived for at least the period of time specified in 40 CFR 61 Subpart $H$.

\section{Quality Control (QC) for 2000 Radiological Usage Inventory Update and Modeling}

\section{Radiological Usage Inventory and Modeling QC}

Approximately $15 \%$ of the 168 potential sources for which emissions were estimated for 2000 were selected for validation. Six sources were selected because they represent the most significant contributions to dose, 16 additional sources were selected randomly. The sources selected for quality control review were the following: one from Site 300 firing tables; four from Building 151; three from Building 612; two from Building 331; and one each from Buildings 194, 231, 235, 241, 254, 281, 298, 361, 363, 364, 378, and 514. An EPD Environmental Analyst contacted the responsible party who signed the NESHAPs usage inventory forms and, when necessary, physically visited and inspected the facilities to verify usage inventory data. The responsible party was asked to demonstrate how he/she arrived at the data submitted. Stack parameters also were verified. The QC data were compared to the original data. The accuracy of the usage inventory data was confirmed.

The analyst performing the QC also modeled the radionuclide usage inventories (or emissions data) and stack data from the NESHAPs usage inventory forms and pertinent distances from site maps on a different computer, using a different copy of the CAP88-PC model. The QC modeling process revealed an error in the initial evaluation of the 612 yard diffuse source, i.e., the source height was incorrect. Because the CAP88-PC model is especially sensitive to source height and because the 612 yard is one of the major contributors to total dose, this error had an impact on the total dose calculation for the Livermore site. The error was corrected. The data that are presented in the attached spreadsheet are as accurate as possible, demonstrating that quality assurance objectives are being met. 
LLNL NESHAPs Report 2000

\section{EPA Compliance Evaluation Investigation}

There were no compliance evaluations of LLNL facilities in 2000. 


\section{Attachment 1. LLNL NESHAPs 2000 Annual Report Spreadsheet}

\section{Guidance for Interpreting Attachment 1}

A generalized description of each facility and its operations is provided on the spreadsheet. In addition, the following information is shown for each listed emission point or stack:

- $\quad$ Building and room number(s)

- $\quad$ Specific stack identification code(s)

- Generalized description of operations in the room(s) or area(s)

- $\quad$ Radionuclides utilized in the operation

- Annual radionuclide usage inventory with potential for release (by isotope, in curies)

- $\quad$ Physical state factors (by isotope)

- $\quad$ Stack parameters

- Emission control devices and emission control device abatement factors

- $\quad$ Estimated or measured annual emissions (by isotope)

- $\quad$ Distance and direction to the site-wide maximally exposed individual (SW-MEI)

- $\quad$ Calculated EDE to the SW-MEI

- Distance and direction to the maximally exposed individual for that specific source (MEI)

- Calculated EDE to the MEI (source term not adjusted for emission controls)

- $\quad$ Source category

\section{Radionuclides}

The radionuclides shown in the spreadsheet are those from specific emission points where air emissions were possible. If radionuclides were present, but encapsulated or sealed for the entire year, radionuclides, annual usage inventories, and emissions are not listed.

\section{Radionuclide Usage Inventories with Potential for Release}

The annual radionuclide usage inventories for point source locations are based on data from facility experimenters and managers. For Buildings 251 (hardened area) and 332, classification issues regarding transuranic radionuclide usage inventories make use of the usage inventory/modeling approach impractical. However, all such affected emission points in these buildings are continuously 
monitored, and emissions are therefore directly determined. LLNL conducted a complete radionuclide usage inventory update for 2000 .

\section{Physical State Factors}

The physical state factors listed are EPA potential release fractions from 40 CFR 61, Appendix D, whereby emissions are estimated from radionuclide usage inventories depending on their physical states for use in dispersion/dose assessment modeling. A physical state factor of $1.0 \times 10^{-6}$ is used for solids, $1.0 \times$ $10^{-3}$ is used for liquids and powders, and 1.0 is used for unconfined gases. The U.S. EPA has granted approved alternative emissions factors for elemental uranium, uranium/niobium alloy, and elemental plutonium. (See Table 4, page 16.) These factors are allowed provided that the material is not intentionally dispersed to the environment and that the processes do not alter the chemical form of the material.

\section{Stack Parameters}

Engineering surveys conducted from 1990 through 1992 form the basis for the stack physical parameters shown, which were checked and validated by facility experimenters and managers for 1994 and 1995. Stack physical parameters for sources evaluated in 2000 were updated, as necessary, by experimenters and managers for those facilities.

\section{Emission Control Devices}

High Efficiency Particulate Air (HEPA) filters are used in many LLNL facilities to control particulate emissions. For some discharge points, scrubbers and electrostatic precipitators aid the control of emissions. The operational performance of all HEPA filtration systems is routinely tested. The required efficiency of a single stage HEPA filter is $99.97 \%$. Double staged filter systems are in place on some discharge points. Triple stage HEPA filters are used on glove box ventilation systems in the Building 332 Plutonium Facility and in the hardened portion of Building 251.

\section{Control Device Abatement Factors}

Similar to physical state factors, control device abatement factors, from Table 1 in 40 CFR 61, Appendix D, are those associated with the listed emission control devices, and are used to better estimate actual emissions for use in dispersion and dose models. By regulation, each HEPA filter stage is given a 0.01 factor (even though the required test efficiency that all LLNL HEPA filters must maintain would yield a factor of 0.0003 ). 


\section{Estimated Annual Emissions}

For unmonitored and non-continuously monitored sources, estimated annual emissions for each radionuclide are based on the product of (1) usage inventory data, (2) time factors (discussed in "Emission Source Terms" of in Section III, (3) EPA potential release fractions (physical state factors), and (4) applicable emission control device abatement factors.

Actual emission measurements are the basis for reported emissions from continuously monitored facilities. LLNL facilities that had continuous monitoring systems at the beginning of 2000 were Buildings 175, 177, 251, 331, 332, and 491; as noted earlier. See the subsection titled "2000 Usage inventory Update and Effective Dose Equivalent (EDE) Calculations" for a discussion of the use of emissions measurements for monitored sources.

\section{$10 \mathrm{mrem} / \mathrm{y}$ Site-Wide Dose Requirement}

For LLNL to comply with the NESHAPs regulations, the LLNL site-wide maximally exposed individual (SW-MEI; defined as the hypothetical member of the public at a single residence, school, business, or office who receives the greatest LLNL-induced EDE from the combination of all radionuclide source emissions) cannot receive an EDE greater than $10 \mathrm{mrem} / \mathrm{y}(100 \mu \mathrm{Sv} / \mathrm{y})$.

In Attachment 1, the distance and direction to the respective SW-MEI are shown for each facility at each site. Doses to the site specific SW-MEIs were evaluated for each source and then totaled for site specific evaluations against the $10 \mathrm{mrem} / \mathrm{y}$ dose standard (see "Total Dose Estimate" in Section IV).

\section{$0.1 \mathrm{mrem} / \mathrm{y}$ Monitoring Requirement}

To assess compliance with the requirement for continuous monitoring (potential dose greater than $0.1 \mathrm{mrem} / \mathrm{y}[1.0 \mu \mathrm{Sv} / \mathrm{y}]$ ), emissions must be individually evaluated from each point source; the location of the maximally exposed public individual (MEI) is generally different for each emission point. The maximum dose at a location of unrestricted public access typically occurs at a point on the site perimeter. Therefore, it is often referred to as the maximum "fence line" dose, although the off-site maximum dose could occur some distance beyond the perimeter. (This could happen, e.g., when the perimeter is close to a stack; however, for all emission points at the Livermore site and Site 300 , calculations show that ground level concentrations of radionuclides decline monotonically beyond LLNL boundaries.) As stipulated by the regulations, modeling for assessment of continuous monitoring requirements assumed unabated emissions (i.e., no credit was taken for emission abatement devices, such as filters), but physical state factors and time factors were applied. 
The unabated EDE cannot be calculated for monitored facilities. Because the monitoring equipment is placed after HEPA filtration, there is no way to obtain an estimate for what the emissions might have been had there been no filtration. It is not reasonable to apply factors for the effects of the HEPA filters on the emission rate because most of what is measured on the HEPA filters is the result of the radioactive decay of radon, which is capable of penetrating the filter. Attachment 1 gives, for each inventoried point source, the dose to the MEI and the distance and direction to the LLNL fence line where the MEI is located. However, for monitored sources, no value is shown.

\section{Source Categories}

LLNL radionuclide air emission sources have been classified into seven source categories, indicated by the number in the next to last column of the spreadsheet: (1) Unmonitored or non-continuously monitored Livermore-site facilities that have had a radionuclide usage inventory update for 2000; (2) Unmonitored or non-continuously monitored Livermore site facilities with a previous radionuclide usage inventory update (this category is not used in years with complete usage inventory updates, such as 2000); (3) Continuously monitored Livermore site facilities; (4) Site 300 explosives experiments; (5) Diffuse sources where emissions and subsequent doses were estimated using inventory processes; (6) Diffuse sources where emission and dose estimates were supported by environmental surveillance measurements; and (7) Sources whose emissions estimates and subsequent doses were estimated based on periodic confirmatory air sampling rather than continuous sampling. 
Attachment 1 - 2000 LLNL NESHAPs Annual Report Spreadsheet

\begin{tabular}{|c|c|c|c|c|c|c|c|c|c|c|c|c|c|c|c|c|c|c|c|}
\hline Building & Room/Area & Stack ID & Operation & Radionuclides & $\begin{array}{l}\text { Annual Inventory } \\
\text { with Potentit Ior }\end{array}$ & \begin{tabular}{|l|} 
Physical \\
State
\end{tabular} & $\begin{array}{c}\text { Stack } \\
\text { Heibt (m) }\end{array}$ & $\begin{array}{l}\text { Stack } \\
\text { Dimater }\end{array}$ & Stack & Control & \begin{tabular}{|l|} 
Control Device \\
Ant tevic
\end{tabular} & Estimated & $10 \mathrm{mrem} / \mathrm{Sit}$ & $\begin{array}{l}\text { ite-Wide Dos } \\
\text { thichof }\end{array}$ & ose Requirement & 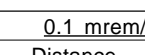 & $y$ Monitoring F & Requirement & Source \\
\hline & & & & & $\begin{array}{l}\text { with Potential for } \\
\text { Release (ii) }\end{array}$ & $\begin{array}{l}\text { State } \\
\text { Factor } \\
\end{array}$ & Height (m) & $\frac{\sum_{\text {Diameter }}}{(m)}$ & $\begin{array}{l}\text { Velocity } \\
\text { m/s/s }\end{array}$ & Device(s) & $\begin{array}{l}\text { Abatement } \\
\text { Factor }\end{array}$ & $\begin{array}{l}\text { Annual Emissions } \\
\text { (Ci) }\end{array}$ & $\begin{array}{l}\text { Distance to } \\
\text { SwMEIm) }\end{array}$ & $\begin{array}{l}\text { Direction } \\
\text { to sWMEI }\end{array}$ & \begin{tabular}{|c|c|} 
EDE \\
(remem)
\end{tabular} & $\begin{array}{l}\text { Distance } \\
\text { Do MEI }(m)\end{array}$ & $\begin{array}{l}\text { Direction } \\
\text { to MEI }\end{array}$ & $\begin{array}{l}\text { Unabated } \\
\operatorname{EDE~(mmerm)~}\end{array}$ & \\
\hline NOTE: C & AP88-PC requires & activity rates of curies/year and & gives doses in mrem/year. To cor & nvert curies to beco & uerels use 1 Ci $=3.7$ & $E+10 \mathrm{~Bq}$ and $\mathrm{t}$ & to convert millirer & in to sieverts us & $S v=1.0 E+0$ & 5 mrem. & & & & & & & & & \\
\hline 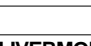 & 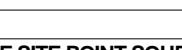 & & & & & & & & & & & & & & & & & & \\
\hline LVERMO & ESITE POINT SOUF & & & & & & & & & & & & & & & & & & \\
\hline Building & 31 complex is a lar & e officel/aboratory facility housin & both Mechanical a & gineering Divisions. & & & & & & & & & & & & & & & \\
\hline-5 & 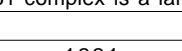 & 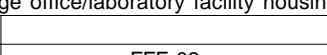 & born wecramical and Elecirical Ens & gineering vivisions. & & & & & & & & & & & & & & & \\
\hline 131 & 1221 & FFE-02 & $\begin{array}{l}\text { Storage and dleaning of } \\
\text { assemblies }\end{array}$ & $\frac{U-238}{U-235}$ & $\begin{array}{l}6.1 E=-06 \\
7.95-08 \\
7\end{array}-3$ & \begin{tabular}{|l|l|}
$1.0 \mathrm{E}-06$ \\
$1.0 \mathrm{E}-06$ \\
\end{tabular} & 12.2 & 0.15 & 7.8 & HEPA & 1 & $\begin{array}{l}6.1 E-12 \\
7.9 E-14\end{array}$ & 1326 & $\mathrm{E}$ & 3.1E-12 & 567 & wnw & 1.4E-09 & 1 \\
\hline & & & & U-234 & $5.7 E-07$ & $1.0 \mathrm{E}-06$ & & & & & & $5.7 E-13$ & & & & & & & \\
\hline 131 & 1248 & Room Air & Storage and display of & U-238 & $1.5 E-06$ & $1.0 \mathrm{E}-06$ & NA & NA & NA & None & 1 & $1.5 \mathrm{E}-12$ & 1326 & $\mathrm{E}$ & $8.6 \mathrm{E}-11$ & 524 & w & $1.4 \mathrm{E}-09$ & 1 \\
\hline & & & & $\begin{array}{lll}-2-235 \\
-234 \\
\end{array}$ & $\begin{array}{l}2.0=-08 \\
1.45-07\end{array}$ & \begin{tabular}{|l|}
$.10 \mathrm{E}-0 \mathrm{6}$ \\
$1.0 \mathrm{E}-06$ \\
\end{tabular} & & & & & & $\begin{array}{l}2.0 E-14 \\
1.4 E-13\end{array}$ & & & & & & & \\
\hline 131 & $1248 \mathrm{~A}$ & Room Air & Storage and display of & U-238 & $7.7 E-07$ & $1.0 \mathrm{E}-06$ & NA & NA & NA & None & 1 & $7.7 E-13$ & 1326 & $\mathrm{E}$ & $4.3 \mathrm{E}-11$ & 524 & w & $6.9 E-10$ & 1 \\
\hline & & & post-test materials & $\begin{array}{l}U-235 \\
U-234 \\
\end{array}$ & $\begin{array}{l}9.9 E-09 \\
72-08\end{array}$ & $\begin{array}{l}\frac{1.0 \mathrm{E}-06}{1.0 \mathrm{E}-06} \\
\end{array}$ & & & & & & $\begin{array}{l}9.9 E-15 \\
72-14\end{array}$ & & & & & & & \\
\hline & & & & & & & & & & & & & & & & & & & \\
\hline Building 1 & 32 provides office $a$ & boratory space for & Directorate & Offices for $\mathrm{Ch}$ & and Materials $\mathrm{s}$ & nces & & & & & & & & & & & & & \\
\hline laboratorii & $\begin{array}{l}s \text { in the Analytical } \\
\text {. }\end{array}$ & Nuclear Chemistry Division and & Chemistry and Chemical Engineering & 9 Division; and NAI D & ectorate Forensic S & ciences Cente & Ir offices and labor & ratories. & & & & & & & & & & & \\
\hline $132 \mathrm{~N}$ & 2671 & FHE-6000/7000 & Mass spectrometry analysis & $\mathrm{U}-234$ & $8.0 E-17$ & $1.0 \mathrm{E}-06$ & 38.1 & 2.10 & 11.2 & None & 1 & $8.0 E-23$ & 1504 & E & $2.0 E-17$ & 481 & SW & $3.1 \mathrm{E}-17$ & 1 \\
\hline & & & & U-235 & $\begin{array}{l}\frac{1.0 E-14}{1.4-12} \\
1.12\end{array}$ & \begin{tabular}{|l|}
$1.0 \mathrm{E}-06$ \\
$1.0 \mathrm{E}-06$
\end{tabular} & & & & & & $\begin{array}{l}1.0 E-20 \\
1.4=18\end{array}$ & & & & & & & \\
\hline & & & & $\mathrm{U}-234$ & $4.0 E-23$ & $1.0 \mathrm{E}-03$ & & & & & & $4.0 E-26$ & & & & & & & \\
\hline & & & & $\frac{U-235}{U-238}$ & $\begin{array}{l}5.0 E-21 \\
6.9-19 \\
6\end{array}$ & $\begin{array}{l}\frac{1.0 \mathrm{E}-03}{1.0 \mathrm{E}-03} \\
\end{array}$ & & & & & & $\begin{array}{l}5.0 E-24 \\
6.9-2-22 \\
6\end{array}$ & & & & & & & \\
\hline $132 \mathrm{~N}$ & 2675 & FHE-6000/7000 & Preparation of aqueous & U-234 & $2.6 \mathrm{E}-18$ & $1.0 \mathrm{E}-03$ & 38.1 & 2.13 & 8.6 & None & 1 & $2.6 \mathrm{E}-21$ & 1504 & E & $6.7 E-16$ & 481 & SW & $1.0 \mathrm{E}-15$ & 1 \\
\hline & & & & $\begin{array}{l}-233 \\
U-238\end{array}$ & $\begin{array}{l}3.3 \mathrm{E}-16 \\
4.6 \mathrm{E}-14\end{array}$ & \begin{tabular}{|l|}
$1.0 \mathrm{E}-03$ \\
$1.0 \mathrm{E}-03$ \\
\end{tabular} & & & & & & $\begin{array}{l}3.3 E-19 \\
4.6 E-17\end{array}$ & & & & & & & \\
\hline & & FHE-6000/7000 & Analysis of aqueous solutions & U-234 & $\begin{array}{l}1.3 \mathrm{E}-14 \\
1.75-12\end{array}$ & $\begin{array}{l}1.0 E+00 \\
1.0 E+00\end{array}$ & 38.1 & 2.13 & 8.6 & HEPA & 0.01 & $1.3 \mathrm{E}-16$ & 1504 & $E$ & $3.3 E-11$ & 481 & sw & $5.2 \mathrm{E}-09$ & 1 \\
\hline & & & & U-238 & $2.3 \mathrm{E}-10$ & $\begin{array}{l}1.0 E+00 \\
1.0 E+00\end{array}$ & & & & & & $2.3 \mathrm{E}-12$ & & & & & & & \\
\hline $132 \mathrm{~N}$ & 2679 & FHE-60000/7000 & Preparation of aqueous & U-234 & $3.7 E-17$ & $1.0 E+00$ & 38.1 & 2.13 & 8.6 & HEPA & 0.01 & $3.7 E-19$ & 1504 & E & $1.3 \mathrm{E}-12$ & 481 & sw & $2.0 E-10$ & 1 \\
\hline & & & solutions for analysis & $\frac{U-235}{U-238}$ & $\begin{array}{l}\frac{1.5 E-14}{7.4 \mathrm{E}-12} \\
\end{array}$ & \begin{tabular}{|l|l|}
$.0 E+00$ \\
$1.0 E+00$
\end{tabular} & & & & & & $\begin{array}{l}1.5 .5-16 \\
7.4 E-14\end{array}$ & & & & & & & \\
\hline & & & & Th-232 & $5.5 \mathrm{E}-13$ & $1.0 E+00$ & & & & & & $5.5 E-15$ & & & & & & & \\
\hline $132 \mathrm{~N}$ & 2685 & FHE-6000/7000 & Transfer and solvent extraction & Cs-137 & $8.8 \mathrm{E}-09$ & $1.0 \mathrm{E}-03$ & 38.1 & 2.13 & 8.6 & None & 1 & $9.0 E-12$ & 1504 & $E$ & $3.8 \mathrm{E}-11$ & 481 & SW & $6.2 E-11$ & 1 \\
\hline & & & $\begin{array}{l}\text { of waste samples } \\
\text { for PCB analysis }\end{array}$ & $\frac{0.60}{\text { St-90 }}$ & $\begin{array}{l}\frac{4.4 E-10}{4.8-09} \\
4.8-59\end{array}$ & \begin{tabular}{|l|}
$1.0 \mathrm{E}-03$ \\
$1.0 \mathrm{E}-03$
\end{tabular} & & & & & & $\begin{array}{l}4.5 E-13 \\
4.9 E-12\end{array}$ & & & & & & & \\
\hline & & & & $\begin{array}{l}\text { Th-228 } \\
\text { Th-230 }\end{array}$ & $\begin{array}{l}3.4 \mathrm{E}-13 \\
1.0 \mathrm{E}-12\end{array}$ & $\begin{array}{c}1.0 \mathrm{E}-03 \\
1.0 \mathrm{E}-03\end{array}$ & & & & & & $\begin{array}{l}3.5 E-16 \\
10 E-15\end{array}$ & & & & & & & \\
\hline & & & & Th-232 & 7.2E-14 & $1.0 \mathrm{E}-03$ & & & & & & $7.4 E-17$ & & & & & & & \\
\hline & & & & $\begin{array}{l}\text { Pu-238 } \\
\text { Pu-239 }\end{array}$ & $\begin{array}{l}1.0 E-11 \\
4.4 E-10\end{array}$ & $\begin{array}{l}1.0 \mathrm{E}-03 \\
1.0 \mathrm{E}-03\end{array}$ & & & & & & $\begin{array}{l}1.1 E-14 \\
4.5 E-13 \\
4.51\end{array}$ & & & & & & & \\
\hline & & & & Pu-240 & $2.7 E-10$ & $1.0 \mathrm{E}-03$ & & & & & & $2.8 E-13$ & & & & & & & \\
\hline & & & & $\begin{array}{l}\text { Pul-241 } \\
\text { Am-241 }\end{array}$ & $\begin{array}{l}2.4 \mathrm{EE}-10 \\
2.4 \mathrm{E}-11\end{array}$ & $\begin{array}{l}\frac{1.0 \mathrm{E}-03}{1.0 \mathrm{E}-03} \\
\end{array}$ & & & & & & $\begin{array}{l}2.5 E-13 \\
2.5 E-14\end{array}$ & & & & & & & \\
\hline & & & & U-234 & $6.8 \mathrm{E}-12$ & $1.0 \mathrm{E}-03$ & & & & & & $7.0 \mathrm{E}-15$ & & & & & & & \\
\hline & & & & $\begin{array}{ll}0-353 \\
\text { U- } 238 \\
\end{array}$ & $\begin{array}{l}3.9 E-13 \\
1.2 E-12\end{array}$ & \begin{tabular}{|l|}
$1.0 E-0$ \\
$1.0 E-03$ \\
\end{tabular} & & & & & & $\begin{array}{l}\frac{4.0 E-16}{1.2 E-15} \\
\frac{1}{4}\end{array}$ & & & & & & & \\
\hline $132 \mathrm{~N}$ & 2694 & FHE-6000/7000 & Transfer and solvent extraction & Cs-137 & $5.7 E-09$ & $1.0 \mathrm{E}-03$ & 38.1 & 2.13 & 8.6 & None & 1 & $5.7 E-12$ & 1504 & E & $2.5 E-11$ & 481 & Sw & $3.9 E-11$ & 1 \\
\hline & & & $\begin{array}{l}\text { of waste samples } \\
\text { for volatiles analysis }\end{array}$ & $\frac{00-60}{\text { Sr-90 }}$ & $\begin{array}{l}2.7 E-10 \\
3.0 E-09\end{array}$ & 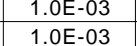 & & & & & & 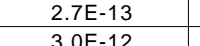 & & & & & & & \\
\hline & & & & Th-228 & $2.2 E-13$ & $1.0 \mathrm{E}-03$ & & & & & & $\frac{2.25-16}{2.25}$ & & & & & & & \\
\hline & & & & Th-230 & $6.5 E-13$ & 1.0E-03 & & & & & & $6.5 E-16$ & & & & & & & \\
\hline & & & & $\begin{array}{l}\text { Th-232 } \\
\text { Pu-238 }\end{array}$ & $\begin{array}{l}4.4 E-14 \\
6.5 E-12\end{array}$ & $\begin{array}{l}\frac{1.0 \mathrm{E}-03}{1.0 \mathrm{E}-03} \\
\end{array}$ & & & & & & $\begin{array}{l}4.45-17 \\
6.5 E-15\end{array}$ & & & & & & & \\
\hline & & & & Pu-239 & $2.9 E-10$ & $1.0 \mathrm{E}-03$ & & & & & & $2.9 E-13$ & & & & & & & \\
\hline & & & & $\begin{array}{l}\text { Pu-240 } \\
\text { Pu-241 }\end{array}$ & 1.8-10-10 $1.5-10$ & $\begin{array}{l}1.0=-03 \\
10=-03\end{array}$ & & & & & & 年.8E-13 & & & & & & & \\
\hline & & & & $\begin{array}{ll}\text { Am-241 } \\
\text { U-234 }\end{array}$ & $\begin{array}{l}1.5 E-11 \\
4.3-12 \\
4-12\end{array}$ & $\begin{array}{c}\frac{1.0 \mathrm{E}-03}{1.0 \mathrm{E}-03} \\
\end{array}$ & & & & & & $\begin{array}{l}1.5 \mathrm{E} \\
4.3 \mathrm{E} \\
\end{array}$ & & & & & & & \\
\hline & & & & U-235 & $2.05-10$ & $1.0 \mathrm{E}-03$ & & & & & & & & & & & & & \\
\hline & & & & & & & & & & & & $7.8 E-16$ & & & & & & & \\
\hline
\end{tabular}


Attachment 1 - 2000 LLNL NESHAPs Annual Report Spreadsheet

\begin{tabular}{|c|c|c|c|c|c|c|c|c|c|c|c|c|c|c|c|c|c|c|c|}
\hline Building & Room/Area & Stack ID & Operation & Radionuclides & Annual Inventory & $\begin{array}{ll}\text { Physical } \\
\text { yisa }\end{array}$ & $\begin{array}{ll}\text { Stack } \\
\text { Hach }\end{array}$ & Stack & Stack & Control & Control Device & $\begin{array}{l}\text { Estimated } \\
\text { Estrexcion }\end{array}$ & $\frac{10 \mathrm{mrem} / \mathrm{y} \mathrm{S}}{\text { Distane the }}$ & $\begin{array}{lll}\text { ite-Wide Dos } \\
\text { Dinctiont }\end{array}$ & \begin{tabular}{l|l} 
ose Requirement \\
IfE
\end{tabular} & $\frac{0.1 \mathrm{mrem}}{\text { Distance }}$ & $\begin{array}{l}y \text { Monitoring } \\
\text { Diring }\end{array}$ & $\begin{array}{l}\text { Requirement } \\
\text { Innhator }\end{array}$ & $\begin{array}{c}\text { Source } \\
\text { Catacorry }\end{array}$ \\
\hline & & & & & $\begin{array}{c}\text { with Potential for } \\
\text { Release (Ci) } \\
\end{array}$ & $\begin{array}{l}\text { State } \\
\text { Factor } \\
\end{array}$ & Height (m) & $\frac{\text { Diameter }}{(m)}$ & $\begin{array}{c}\text { Velocity } \\
\text { (m/s) }\end{array}$ & Device(s) & $\begin{array}{l}\text { Abatement } \\
\text { Factor } \\
\end{array}$ & $\begin{array}{l}\text { Annual Emisions } \\
\text { (Ci) }\end{array}$ & $\begin{array}{l}\text { Distance to } \\
\text { SWMEI (m) }\end{array}$ & $\begin{array}{l}\text { Direction } \\
\text { to SWMEI }\end{array}$ & \begin{tabular}{|l|} 
(me \\
(mrem) \\
\end{tabular} & $\begin{array}{l}\text { Dilsance } \\
\text { to MEI (m) }\end{array}$ & $\begin{array}{l}\text { Direction } \\
\text { to MEI }\end{array}$ & \begin{tabular}{|l} 
Unabated \\
$\operatorname{EDE}($ mrem) \\
\end{tabular} & \\
\hline $132 \mathrm{~N}$ & 2870 & FHE-6000/7000 & Preparation of uranium sol-gels & $\mathrm{U}-234$ & $4.0 E-07$ & $1.0 \mathrm{E}-03$ & 38.1 & 2.13 & 8.6 & None & 1 & $4.0 E-10$ & 1504 & E & $1.0 \mathrm{E}-04$ & 481 & SW & $1.5 \mathrm{E}-04$ & 1 \\
\hline & & & & $\frac{U-235}{U-238}$ & $\begin{array}{l}5.0 \mathrm{E}-5 \mathrm{5} \\
6.9 \mathrm{E}-03\end{array}$ & 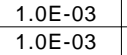 & & & & & & $\begin{array}{l}5.0 E-08 \\
6.9 E-06\end{array}$ & & & & & & & \\
\hline & & & & & & & & & & & & & & & & & & & \\
\hline 1325 & 2788 & FHE-6000/7000 & Transfer of uranium & U-238 & $5.7 E-10$ & $1.0 \mathrm{E}-03$ & 4.6 & 1.22 & 8.9 & None & 1 & $5.7 E-13$ & 1504 & $\mathrm{E}$ & $2.1 E-11$ & 453 & sw & $7.4 E-11$ & 1 \\
\hline & & & & $\frac{U-235}{U U-234}$ & $\frac{7.3 \mathrm{E}-12}{5.3 \mathrm{E}-11}$ & $\begin{array}{ll}1.0 \mathrm{E}-03 \\
1.0 \mathrm{E}-03\end{array}$ & & & & & & 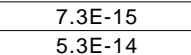 & & & & & -1 & & \\
\hline Building 1 & 1 houses the Iso & Sciences Division whi & & wide range of prob & ms. including stockpi & estemardshit & , nonproliferati & sateouard th & Iocies, fore & & (c) & and & & & & & & & \\
\hline Building 1 & 1 also contains t & nemistry and Materials & 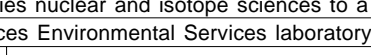 & where samples of & vaste streams and er & 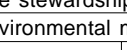 & nedia (air, wate & 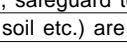 & 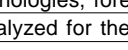 & $\begin{array}{l}\text { ic scielence, and waste } \\
\text { radionuclide content. }\end{array}$ & characterzzation & and analysis. & & & & & & & \\
\hline 151 & 1033 & FHE-2 & $\begin{array}{l}\text { Evaporation and transfer } \\
\text { of solutions }\end{array}$ & $\begin{array}{l}\mathrm{Cm}-248 \\
\mathrm{Cm}-246\end{array}$ & $\begin{array}{l}3.5 \mathrm{E}-07 \\
8.3 \mathrm{E}-07\end{array}$ & $\begin{array}{l}1.0 \mathrm{E}-03 \\
1.0 \mathrm{E}-03 \\
\end{array}$ & 12.8 & 0.41 & 7.8 & None & 1 & $\frac{3.5 E-10}{8.3 E-10}$ & 1308 & E & $\begin{array}{l}4.4 E-07 \\
\end{array}$ & 768 & SW & $1.1 \mathrm{E}-06$ & 1 \\
\hline & & & & U-233 & $1.9 \mathrm{E}-09$ & $\begin{array}{ll}1.0 E-03 \\
1.0502\end{array}$ & & & & & & $\begin{array}{l}1.9 E-12 \\
25-1.1\end{array}$ & & 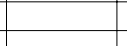 & & & & & 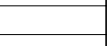 \\
\hline & & & & $\begin{array}{l}\text { Np-237 } \\
\text { Pu-2244 }\end{array}$ & $\begin{array}{ll} & \end{array}$ & $\begin{array}{l}1.0 E-03 \\
1.0 E-03 \\
\end{array}$ & & & & & & $\begin{array}{l}3.8 \mathrm{E}-11 \\
1.8 \mathrm{E}-14\end{array}$ & & & & & & & \\
\hline 151 & 1034B & Room Air & Sample preparation & Am-241 & $6.9 \mathrm{E}-05$ & $1.0 \mathrm{E}-03$ & NA & NA & NA & Double HEPA & 0.0001 & $6.9 \mathrm{E}-12$ & 1308 & E & $2.6 \mathrm{E}-08$ & 540 & w & $2.9 \mathrm{E}-03$ & 1 \\
\hline & & & & $\begin{array}{l}\text { Pu-238 } \\
\text { Pu-239 }\end{array}$ & $\begin{array}{l}3.4 E-05 \\
1.2 \mathrm{E}-03 \\
\mathrm{n}\end{array}$ & 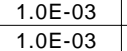 & & & & & & 3.4E-12 & & & & & & & \\
\hline & & & & $\begin{array}{l}\text { Pu-240 } \\
\text { Put221 }\end{array}$ & $\begin{array}{l}2.6 E-04 \\
4.1-03\end{array}$ & $\begin{array}{ll}1.0 \mathrm{E}-03 \\
1.0 \mathrm{E}-03\end{array}$ & & & & & & $\begin{array}{l}2.6 \mathrm{E}-11 \\
4.1 \mathrm{E}-10\end{array}$ & & & & & & & \\
\hline & & & & Pu-242 & $\frac{1.1 E-05}{1.5-06}$ & $\begin{array}{l}1.0 E-03 \\
10 E-06\end{array}$ & & & & & & 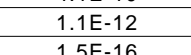 & & & & & & & 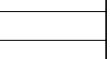 \\
\hline & & & & Pu-238 & $3.22-07$ & $\begin{array}{l}1.0 \mathrm{E}-06 \\
1.06\end{array}$ & & & & & & $3.2 \mathrm{E}-17$ & & & & & & & 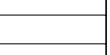 \\
\hline & & & & $\begin{array}{l}\text { Puv-239 } \\
\text { Pu-240 }\end{array}$ & $\begin{array}{l}\frac{1.2 .2-05}{2.7-0.06} \\
2 E-06\end{array}$ & $\begin{array}{l}\frac{1.06-06}{1.06-06} \\
1.06\end{array}$ & & & & & & $\begin{array}{l}\frac{1.2 E-15}{2.7 E-16} \\
2.15\end{array}$ & & & & & & & \\
\hline & & & & $\begin{array}{l}\text { Pu-241 } \\
\text { Pu-242 }\end{array}$ & $\begin{array}{l}\frac{3.0 E-05}{1.7 E-10} \\
10\end{array}$ & $\begin{array}{l}\frac{1.06-06}{1.0 E-06} \\
1.06\end{array}$ & & & & & & $\begin{array}{l}\frac{3.0 E-15}{1.7 E-20} \\
1.5\end{array}$ & & & & & & & \\
\hline 151 & 1039 & FHE-43 & Transfer of solutions & Cs-137 & $4.6 E-10$ & $1.0 \mathrm{E}-03$ & 12.8 & 0.46 & 11.3 & None & 1 & $4.6 E-13$ & 1308 & $E$ & $3.9 E-11$ & 768 & SW & $7.6 \mathrm{E}-11$ & 1 \\
\hline & & & & Gross alpha & $\begin{array}{l}3.2 E-10 \\
3.0 E-10\end{array}$ & $\begin{array}{l}1.0 \mathrm{E}-03 \\
1.03\end{array}$ & & & & & & $\begin{array}{l}3.2 \mathrm{E}-13 \\
3\end{array}$ & & & & & & & \\
\hline 151 & 1123 & FHE-41 & Evaporation and transfer & Pu-239 & $2.5 E-14$ & $1.0 \mathrm{E}-03$ & 12.8 & 0.30 & 6.6 & None & 1 & $2.5 E-17$ & 1308 & $E$ & $3.5 \mathrm{E}-15$ & 768 & sw & $1.0 E-14$ & 1 \\
\hline & & & & & 2.6E-15 & & & & & & & $2.6 E-18$ & & & & & WNw & 1.0E-14 & \\
\hline 151 & 1241 & FHE-68 & Sample preparation and & U-234 & $6.6 \mathrm{E}-04$ & $1.0 \mathrm{E}-03$ & 13.1 & 0.30 & 6.6 & None & 1 & $6.6 \mathrm{E}-07$ & 1308 & $\mathrm{E}$ & 3.4E-04 & 768 & SW & $9.8 E-04$ & 1 \\
\hline & & & radiochemical analysis of uranium & $\begin{array}{l}\mathrm{U}-235 \\
\mathrm{U}-236 \\
\end{array}$ & $\begin{array}{l}8.9 E-05 \\
12 E-06\end{array}$ & $\begin{array}{l}1.0 \mathrm{E}-03 \\
1.0=-03\end{array}$ & & & & & & $\begin{array}{l}8.9 E-08 \\
125-09\end{array}$ & & & & & & & \\
\hline & & & & U-238 & $6.8 \mathrm{E}-03$ & $1.0 \mathrm{E}-03$ & & & & & & $6.8 \mathrm{E}-06$ & & & & & & & \\
\hline 151 & 1303 & FHE-2000 & Sample preparation & U-238 & $8.4 E-13$ & $1.0 E+00$ & 11.9 & 0.48 & 15.4 & None & 1 & $8.4 E-13$ & 1308 & $E$ & 4.4E- -08 & 1125 & NNE & $8.2 E-08$ & 1 \\
\hline & & & and analysis (ICP-MS) & U-234 & $\begin{array}{l}3.9 E E-14 \\
8.4 E-13\end{array}$ & $\begin{array}{l}\frac{1.0 E+00}{1.0 E+00} \\
1.05\end{array}$ & & & & & & $8.4 \mathrm{E}-13$ & & & & & & & 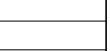 \\
\hline & & & 年 & $\begin{array}{l}\text { U-233 } \\
P_{4}-239\end{array}$ & $\begin{array}{l}1.9 E-10 \\
31=10\end{array}$ & $\begin{array}{l}1.0 E+00 \\
1.05+00\end{array}$ & & & & & & $\frac{1.9 E-10}{315-10}$ & & & & & & & \\
\hline & & & & $\begin{array}{ll}\text { Put-239 } \\
\mathrm{U}-238\end{array}$ & $\begin{array}{l}3.3 E-10 \\
8.4 E-14\end{array}$ & $\begin{array}{l}1.0 \mathrm{E}+00 \\
1.0 \mathrm{E}-03\end{array}$ & & & & & & $\begin{array}{l}3.1 E-10 \\
8.4 E-17\end{array}$ & & & & & & & \\
\hline & & & & $\frac{U-235}{U-234}$ & $\begin{array}{l}3.9 E-15 \\
84 E-14\end{array}$ & $\begin{array}{l}1.0 \mathrm{E}-03 \\
1.0 \mathrm{E}-03\end{array}$ & & & & & & 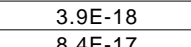 & & & & & & & \\
\hline & & & & U-2233 & 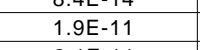 & $\begin{array}{l}1.0 \mathrm{E}-03 \\
1.03\end{array}$ & & & & & & $\begin{array}{l}0.4 \mathrm{~L}-1 / \mathrm{L} \\
1.9 \mathrm{E}-14\end{array}$ & & & & & & & \\
\hline & & & & 19.200 & 51 & 1.4 .45 & & & & & & & & & & & & & \\
\hline 151 & 1304 & FHE-2000 & Sample preparation & Gross alpha & 1.2E -08 & 1.0E-03 & 11.9 & 0.48 & 15.4 & None & 1 & $1.2 E-11$ & 1308 & E & 1.4E-09 & 1125 & NNE & $2.6 \mathrm{E}-09$ & 1 \\
\hline & & & & Gross gamma & $2.0 \mathrm{E}-08$ & $1.0 \mathrm{E}-03$ & & & & & & $\begin{array}{ll}2.0 E-11 \\
2.0 E-11\end{array}$ & & & & & & & \\
\hline 151 & 1318 & FHE-26 & Sample preparation & Pu-239 & $1.0 E-09$ & $1.0 \mathrm{E}-03$ & 13.1 & 0.36 & 7.4 & None & 1 & $1.0 \mathrm{E}-12$ & 1308 & E & $1.8 \mathrm{E}-10$ & 768 & SW & $4.8 \mathrm{E}-10$ & 1 \\
\hline & & & & $\frac{\mathrm{Am}-241}{\mathrm{Cm}-244}$ & $\begin{array}{l}2.00-10 \\
1.0 E-10\end{array}$ & $\begin{array}{l}\frac{1.0 E-03}{1.0 E-03} \\
1.04\end{array}$ & & & & & & $\begin{array}{l}\frac{2.0 E-13}{1.0 E-13} \\
13\end{array}$ & & & & & & & \\
\hline 151 & 1322 & FHE-33 & Sample preparation & Gross alpha & $6.0 E-08$ & $1.0 \mathrm{E}-03$ & 12.8 & 0.36 & 8.1 & None & 1 & $6.0 E-11$ & 1308 & $E$ & $1.2 E-05$ & 768 & SW & $3.1 E-05$ & 1 \\
\hline & & & & $\begin{array}{l}\text { Gross beta } \\
\text { Gross gamma }\end{array}$ & $\begin{array}{l}\frac{1.0 E-07}{1.0 E-07} \\
1.07\end{array}$ & $\begin{array}{ll}1.0 \mathrm{E}-03 \\
1.0 \mathrm{E}-03\end{array}$ & & & & & & 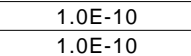 & & & & & & & \\
\hline & & & & $\begin{array}{l}u-238 \\
-225\end{array}$ & $2.4 E-04$ & $1.0 \mathrm{E}-03$ & & & & & & $2.4 E-07$ & & & & & & & \\
\hline & & & & $=0 .-235$ & $\begin{array}{l}3.1 .06 \\
20=05\end{array}$ & 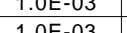 & & & & & & 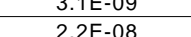 & & & & & & & \\
\hline
\end{tabular}


Attachment 1 - 2000 LLNL NESHAPs Annual Report Spreadsheet

\begin{tabular}{|c|c|c|c|c|c|c|c|c|c|c|c|c|c|c|c|c|c|c|c|}
\hline Building & Room/Area & Stack ID & Operation & Radionuclides & $\begin{array}{l}\text { Annual Inventory } \\
\text { with Potential for }\end{array}$ & $\begin{array}{l}\text { Physical } \\
\text { State }\end{array}$ & $\begin{array}{l}\text { Stack } \\
\text { Height (m) }\end{array}$ & $\begin{array}{l}\text { Stack } \\
\text { Diameter }\end{array}$ & $\begin{array}{l}\text { Stack } \\
\text { Velocity }\end{array}$ & $\begin{array}{l}\text { Control } \\
\text { Device(s) }\end{array}$ & $\begin{array}{c}\text { Control Device } \\
\text { Abatement }\end{array}$ & $\begin{array}{c}\text { Estimated } \\
\text { Annual Emissions }\end{array}$ & $\frac{10 \text { memm/y }}{\text { Distance to }}$ & D. Wide Do & 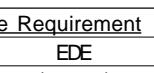 & $\frac{0.1 \mathrm{mrem}}{\text { Distance }}$ & $\begin{array}{l}\text { Monitorinc } \\
\text { Direction }\end{array}$ & $\begin{array}{l}\text { Requirement } \\
\text { Unabated } \\
\end{array}$ & $\begin{array}{l}\text { Source } \\
\text { Category }\end{array}$ \\
\hline & & & & & & & & & & & & & & & & & & & \\
\hline 151 & 1326 & FHE-43 & Sample preparation & MPP & $5.0 \mathrm{E}-05$ & $1.0 E-03$ & 12.8 & 0.36 & 6.8 & None & 1 & $5.0 \mathrm{E}-08$ & 1308 & $E$ & $7.6 \mathrm{E}-08$ & 768 & SW & $2.0 E-07$ & 1 \\
\hline & & & & $\begin{array}{l}06-137 \\
0.134 .\end{array}$ & $2.0 E-08$ & $\begin{array}{l}1.00-03 \\
1.0-03\end{array}$ & & & & & & $\begin{array}{l}2.0 E-11 \\
2.0 E-11\end{array}$ & & & & & & & \\
\hline & & & & $\begin{array}{l}C s-134 \\
C 0.60\end{array}$ & $\begin{array}{l}\frac{1.0 E-08}{2.7 E-07} \\
\end{array}$ & $\begin{array}{l}1.0 E E-03 \\
1.0 E-03\end{array}$ & & & & & & $\begin{array}{l}\frac{1.0 E-11}{2.7 E-10} \\
2.04\end{array}$ & & & & & & & \\
\hline 151 & 1326 & (continued) & & $\begin{array}{l}\text { Bi-207 } \\
\text { Na-22 }\end{array}$ & $\begin{array}{l}2.0 \mathrm{E}-07 \\
2.7 \mathrm{E}-07\end{array}$ & $\begin{array}{l}\frac{1.0 E E-03}{1.0 E-03} \\
1.03\end{array}$ & & & & & & $\begin{array}{l}2.0 E-10 \\
2.7 \mathrm{E}-10\end{array}$ & & & & & & & \\
\hline & & & & $\begin{array}{l}\text { Eu-152 } \\
\text { Euu154 }\end{array}$ & $\begin{array}{l}2.7 \mathrm{~F}-09 \\
2.7 \mathrm{E}-09\end{array}$ & $\begin{array}{l}1.0 E=03 \\
1.0-0.03\end{array}$ & & & & & & $\begin{array}{l}\frac{2.7 \mathrm{~F}-12}{2.7 \mathrm{E}-12} \\
\end{array}$ & & & & & & & \\
\hline & & & & $\begin{array}{l}\text { Pu-236 } \\
\text { Puu-238 }\end{array}$ & $\begin{array}{l}1.0 E-06 \\
1.0-0.5\end{array}$ & $\begin{array}{l}\frac{1.0 E=-06}{1.05-06} \\
1.06\end{array}$ & & & & & & $\begin{array}{l}\frac{1.0 E-12}{1.0 E-11} \\
1.06\end{array}$ & & & & & & & \\
\hline & & & & $\begin{array}{l}\text { Pu-239 } \\
\text { Puu-20 }\end{array}$ & $\begin{array}{l}1.0 E-05 \\
10=505\end{array}$ & $\begin{array}{l}1.0 E=-06 \\
10=0.06\end{array}$ & & & & & & $\begin{array}{l}\frac{1.0 E-11}{10 E-11} \\
10 \mathrm{E}-11\end{array}$ & & & & & & & \\
\hline & & & & Pu-242 & $\begin{array}{l}1.06-5 \\
1.0-5 \\
10=55\end{array}$ & $\begin{array}{l}1.00-06 \\
1.05-06\end{array}$ & & & & & & $\begin{array}{l}1.0 E-11 \\
1.0 E-11 \\
11\end{array}$ & & & & & & & \\
\hline & & & & $\begin{array}{ll}P & P u-244 \\
\text { Pu-2241 } & \end{array}$ & $\begin{array}{l}\frac{1.0 E-05}{1.0 E-04} \\
1.05\end{array}$ & $\begin{array}{ll}1.0=-06 \\
1.05-06\end{array}$ & & & & & & $\begin{array}{l}\frac{1.0 E-11}{1.0 E-10} \\
1.0-10\end{array}$ & & & & & & & \\
\hline & & & & Am-243 & $5.0 E-06$ & $1.0 E-06$ & & & $T_{-1}$ & & & $\begin{array}{l}5.0 E-12 \\
5.0 E-12\end{array}$ & & & & & & & \\
\hline & & & & $\begin{array}{lll}0.236 \\
-235\end{array}$ & $\begin{array}{l}3.0 \mathrm{E}-09 \\
3.09\end{array}$ & $\begin{array}{l}1.0 E=06 \\
1.0 E-06\end{array}$ & & & & & & $\begin{array}{l}-6.05-14 \\
3.0 E-15 \\
\end{array}$ & & & & & & & \\
\hline & & & & $\begin{array}{lll}-0.24 \\
\text { Np-237 }\end{array}$ & $\begin{array}{l}\text { 4. } 1 . E-08 \\
1.0 E-07\end{array}$ & $\begin{array}{l}1.0 E=06 \\
1.0 E-06\end{array}$ & & & & & & $\begin{array}{l}4 . K-14 \\
1.0 E-13 \\
13\end{array}$ & & & & & & & \\
\hline & $x_{-1}$ & & & $\frac{T-232}{\text { C- } 249}$ & $\begin{array}{l}\frac{2.2 \mathrm{E}-09}{1.0 \mathrm{E}-06} \\
-\end{array}$ & $\begin{array}{l}\frac{1.0 E E-06}{1.05-06} \\
1.06\end{array}$ & & & & & & $\begin{array}{l}\frac{2.2 E-15}{1.0 E-12} \\
\end{array}$ & & & & & & & \\
\hline & & & & $\frac{\mathrm{Cm}-242}{\mathrm{Cm}-244}$ & $\frac{1.0 E-06}{1.0 E-06}$ & $\begin{array}{l}1.0 E=-06 \\
1.0-06\end{array}$ & & & & & & $\begin{array}{l}\frac{1.0 \mathrm{E}-12}{1.0 \mathrm{E}-12} \\
\end{array}$ & & - & & & & & E \\
\hline & & & & 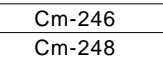 & $\begin{array}{l}\frac{1.0 E-06}{1.0 E-06} \\
\end{array}$ & $\begin{array}{l}1.0 E=-06 \\
1.05-06\end{array}$ & & & & & & $\begin{array}{l}\frac{1.0 \mathrm{E}-12}{1.0 \mathrm{E}-12} \\
\end{array}$ & & & & & & & \\
\hline 151 & 1330 & FHE-52 & Transfer of waste samples & Cs-137 & $9.6 E-08$ & $1.0 \mathrm{E}-03$ & 12.8 & 0.36 & 7.6 & None & 1 & $9.6 \mathrm{E}-11$ & 1308 & $\mathrm{E}$ & $1.2 \mathrm{E}-09$ & 768 & SW & $3.3 E-09$ & 1 \\
\hline & & & for analysis & $\begin{array}{l}0.60 \\
0.60 \\
0.60\end{array}$ & $\begin{array}{l}4.7 E-09 \\
52009\end{array}$ & $\begin{array}{l}1.06-03 \\
1.0=0.03\end{array}$ & & & & & & $4.7 \mathrm{E}-12$ & & & 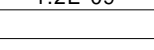 & & the & 年 & \\
\hline & & & & Th-228 & $\begin{array}{l}\frac{5.2 L-08}{3.7 E-12} \\
3 E-12\end{array}$ & $\begin{array}{l}1.0 E=03 \\
1.05-03\end{array}$ & & & & & & $\begin{array}{l}5.7 E-11 \\
3.7 E-15 \\
3\end{array}$ & & & & & & & \\
\hline & & & & Th-232 & $\begin{array}{l}\frac{1.1 E-11}{7.7 E-13} \\
7.5\end{array}$ & $\begin{array}{l}1.0=03 \\
1.0 E-03\end{array}$ & & & ${ }^{2}$ & & & $\begin{array}{l}\frac{1.1 E-14}{7.7 E-16} \\
\end{array}$ & & & & & & & \\
\hline & & & & $\begin{array}{l}\text { Put-283 } \\
\text { Pu-239 }\end{array}$ & $\begin{array}{l}\frac{1.1 E-10}{5.0 E-09} \\
\end{array}$ & $\begin{array}{l}1.0 E=03 \\
1.0 E-03\end{array}$ & & & 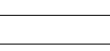 & & & $\begin{array}{l}\frac{1.1 E-13}{5.0 E-12} \\
5.05\end{array}$ & & & & & & & \\
\hline & & & & $\begin{array}{l}\text { Put-240 } \\
\text { Pu-241 }\end{array}$ & $\begin{array}{l}3.0 \mathrm{E}-\mathrm{O}-99 \\
2.6 \mathrm{E}-09\end{array}$ & $\begin{array}{l}1.0 E E-03 \\
1.0 E-03\end{array}$ & & & & & & 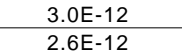 & & & & & & & \\
\hline & & & & $\begin{array}{ll}\text { Am-241 } \\
\text { U-234 }\end{array}$ & $\begin{array}{l}2.6 E-10 \\
7.4 E-11\end{array}$ & $\begin{array}{l}1.0 E=03 \\
1.0-0.03 \\
Y\end{array}$ & & & & & & $\begin{array}{l}2.6 E-13 \\
7.7 E-14\end{array}$ & & & & & & & \\
\hline & & & & U-235 & $\begin{array}{l}4.3 E-12 \\
1.35-11 \\
\end{array}$ & $1.0 E-03$ & & & - & & & $4.3 \mathrm{E}-15$ & & - & & & & & \\
\hline & & & & $\mathrm{H}-38$ & $\begin{array}{l}1.3 \mathrm{E}-11 \\
8.4 \mathrm{E}-12\end{array}$ & $\begin{array}{l}1.0 E=03 \\
1.0 E-03\end{array}$ & & & & & & $\begin{array}{l}\frac{1.3 E-14}{8.4 E-15} \\
\end{array}$ & & & & & & & \\
\hline 151 & 2103 & FHE-6 & Sorption studies & Pu-239 & 1.4E-07 & $1.0 \mathrm{E}-03$ & 12.8 & 0.41 & 7.5 & None & 1 & 1.4E-10 & 1308 & $E$ & $2.5 E-08$ & 768 & SW & $6.5 \mathrm{E}-08$ & 1 \\
\hline & & & & $\begin{array}{l}\text { Pu-240 } \\
\text { Puu-241 }\end{array}$ & $\begin{array}{l}3.1 E-08 \\
4.8 E-07\end{array}$ & $\begin{array}{l}1.0=-03 \\
10=03\end{array}$ & & & & & & $\begin{array}{l}3.1 \mathrm{E}-11 \\
4.8 \mathrm{E}-10 \\
-\end{array}$ & & & & & & & \\
\hline & & & & $\begin{array}{ll}A m-241 \\
\text { Puy-238 }\end{array}$ & $\begin{array}{l}8.4 \mathrm{E}-09 \\
.0 \mathrm{E}-09\end{array}$ & $\begin{array}{l}1.0 E=-03 \\
1.0=5.03\end{array}$ & & & & & & $\begin{array}{l}8.4 \mathrm{E}-12 \\
4.0 \mathrm{E}-12\end{array}$ & & & & & & & \\
\hline 151 & 2107 & FHE-14 & Transfer of solutions & Pu-239 & $2.0 E-13$ & $1.0 E-03$ & 12.8 & 0.41 & 7.3 & None & 1 & $2.0 \mathrm{E}-16$ & 1308 & $\mathrm{E}$ & $3.8 \mathrm{E}-07$ & 768 & SW & $9.8 \mathrm{E}-07$ & 1 \\
\hline & & & & & $\begin{array}{l}4.7-7 E=06 \\
220-07\end{array}$ & $\begin{array}{l}1.0 E-03 \\
1.0=0.32\end{array}$ & & & & & & 4.7.7-09 209 & & & & & & & \\
\hline & & & & $\mathrm{U}-234$ & 3.4E-06 200 & $1.0 E-03$ & & & & & & $3.4 E-09$ & & & & & & & \\
\hline 151 & 2109 & FHE-19 & Collection of daughter products & Th-228 & $1.2 \mathrm{E}-10$ & $1.0 E-06$ & 13.1 & 0.30 & 6.1 & None & 1 & $1.2 E-16$ & 1308 & $\mathrm{E}$ & $1.0 \mathrm{E}-14$ & 584 & WNW & $3.0 \mathrm{E}-14$ & 1 \\
\hline & & & & & & & & & & & & & & & & & & & \\
\hline 151 & 2109 & FHE-15 & Ion exchange studies & Sn-113 & $1.8 \mathrm{E}-08$ & $1.0 \mathrm{E}-03$ & 13.1 & 0.30 & 6.2 & None & 1 & $1.8 E-11$ & 1308 & E & $8.8 E-13$ & 584 & WNW & $2.5 \mathrm{E}-12$ & 1 \\
\hline 151 & 2117 & FHE-23 & Preparation of waste samples & Gross alpha & $9.8 \mathrm{E}-09$ & $1.0 \mathrm{E}-03$ & 12.8 & 0.41 & 8.0 & None & 1 & $9.8 \mathrm{E}-12$ & 1308 & $\mathrm{E}$ & $1.3 E-09$ & 768 & SW & $3.2 E-09$ & 1 \\
\hline & & & for analysis & Gross beta & $2.2 E-10$ & 1.0E-03 & & & & & & $2.2 E-13$ & & & & & & & \\
\hline 151 & 2121 & FHE -36 & Sample preparation & Cs-137 & $9.5 \mathrm{E}-07$ & $1.0 \mathrm{E}-03$ & 12.8 & 0.41 & 8.0 & None & 1 & $9.5 E-10$ & 1308 & $E$ & $1.5 \mathrm{E}-08$ & 768 & SW & $3.8 \mathrm{E}-08$ & 1 \\
\hline & & & & $\frac{0.60}{S r-90}$ & $\begin{array}{l}4.7 E E-08 \\
5.1 E-07\end{array}$ & $\begin{array}{l}\frac{1.0 E E-03}{1.0 E-03} \\
1.03\end{array}$ & & & & & & $\begin{array}{l}\frac{4.7 E-11}{5.1 E-10} \\
\frac{1}{4}\end{array}$ & & & & & & & \\
\hline & & & & Th-228 & 3.7.7E-11 & $\begin{array}{l}1.0 \mathrm{E}=03 \\
1.003\end{array}$ & & & & & & $\begin{array}{l}3.7 E-14 \\
.12+13\end{array}$ & & & & & & & \\
\hline & & & & Th-232 & $7.6 \mathrm{E}-12$ & $1.0 E-03$ & & & & & & 7.6E-15 & & & & & & & \\
\hline & & & & $\begin{array}{l}\text { Pu-2338 } \\
\text { Puus39 }\end{array}$ & $\begin{array}{l}1.111-09 \\
4.9 E-08\end{array}$ & $\begin{array}{l}1.0 E-03 \\
1.0=03\end{array}$ & & & & & & 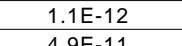 & & & & & & & \\
\hline
\end{tabular}


Attachment 1 - 2000 LLNL NESHAPs Annual Report Spreadsheet

\begin{tabular}{|c|c|c|c|c|c|c|c|c|c|c|c|c|c|c|c|c|c|c|c|}
\hline \multirow{2}{*}{ Building } & \multirow[t]{2}{*}{ Room/Area } & \multirow[t]{2}{*}{ Stack ID } & \multirow[t]{2}{*}{ Operation } & \multirow{2}{*}{ Radionuclides } & \multirow{2}{*}{$\begin{array}{l}\text { Annual Inventory } \\
\text { with Potential for } \\
\text { Release (Ci) }\end{array}$} & \multirow{2}{*}{$\begin{array}{l}\text { Physical } \\
\text { State } \\
\text { Factor }\end{array}$} & \multirow{2}{*}{$\begin{array}{l}\text { Stack } \\
\text { Height (m) }\end{array}$} & \multirow{2}{*}{$\begin{array}{l}\text { Stack } \\
\text { Diameter } \\
\text { (m) }\end{array}$} & \multirow{2}{*}{$\begin{array}{l}\text { Stack } \\
\text { Velocity } \\
(\mathrm{m} / \mathrm{s}) \\
\end{array}$} & \multirow{2}{*}{$\begin{array}{l}\text { Control } \\
\text { Device(s) }\end{array}$} & \multirow{2}{*}{$\begin{array}{c}\text { Control Device } \\
\text { Abatement } \\
\text { Factor }\end{array}$} & \multirow{2}{*}{$\begin{array}{l}\text { Estimated } \\
\text { Annual Emissions } \\
\text { Anis }\end{array}$} & $\frac{10 \text { mrem/y }}{\text { Distanc to }}$ & $\begin{array}{lll}\text { e-Wide D } \\
\text { Dirititon }\end{array}$ & $\begin{array}{l}\text { Requirement } \\
\text { DEE }\end{array}$ & \multicolumn{3}{|c|}{ 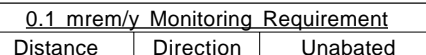 } & \multirow{2}{*}{$\begin{array}{l}\text { Source } \\
\text { Category }\end{array}$} \\
\hline & & & & & & & & & & & & & $\begin{array}{l}\text { Distance e } \\
\text { SWMEI (m) }\end{array}$ & $\begin{array}{l}\text { Drection } \\
\text { to SWMEl }\end{array}$ & Wt & $\begin{array}{l}\text { Siltance } \\
\text { to MEI (m) }\end{array}$ & $\begin{array}{l}\text { Utreccion } \\
\text { to MEI }\end{array}$ & $\begin{array}{l}\text { Unaabaled } \\
\operatorname{EDE}(\mathrm{mrem})\end{array}$ & \\
\hline 151 & 2121 & (continued) & & Pu-240 & $\begin{array}{l}2.9 \mathrm{E}-08 \\
.0 \mathrm{E}\end{array}$ & $\begin{array}{l}1.0 \mathrm{E}-03 \\
1.0-02\end{array}$ & & & & & & $2.95-11$ & & & & & & & \\
\hline & & & & $\begin{array}{l}\text { Au-241 } \\
\text { Am-241 }\end{array}$ & $\begin{array}{l}2.6 \mathrm{E}-08 \\
2.6 \mathrm{E}-09\end{array}$ & $\begin{array}{l}\frac{1.0 \mathrm{E}-03}{1.0 \mathrm{E}-03} \\
\end{array}$ & & & & & & $\begin{array}{l}2.6-6-11 \\
2.6 E-12\end{array}$ & & & & & & & \\
\hline & & & & $\begin{array}{l}\text { U-234 } \\
\text { U-235 }\end{array}$ & $\begin{array}{l}7.3 \mathrm{E}-10 \\
4.3 \mathrm{E}-11\end{array}$ & 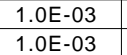 & & & & & & $\begin{array}{l}7.3 \mathrm{E}-13 \\
.3 \mathrm{E}-\mathrm{-14}\end{array}$ & & & & & & & \\
\hline & & & & U-238 & $1.3 \mathrm{E}-10$ & $\begin{array}{l}1.0 E-03 \\
1.0-02\end{array}$ & & & & & & $1.3 \mathrm{E}-13$ & & & & & & & \\
\hline & & & & $\begin{array}{l}\text { Pu-239 } \\
\text { Sr-90 }\end{array}$ & $\begin{array}{l}2.4 \mathrm{E}-\mathrm{-}-8 \\
4.9 \mathrm{E}-10\end{array}$ & $\begin{array}{l}1.0 \mathrm{E}-03 \\
1.0 \mathrm{E}-03\end{array}$ & & 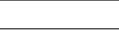 & & & & $\begin{array}{l}2.4 E-11 \\
4.9 E-13\end{array}$ & & & & & & & \\
\hline & & & & $\mathrm{H}-3$ & $\begin{array}{ll}7.3 \mathrm{E}-08 \\
7\end{array}$ & 年 $1.0 \mathrm{E}-03$ & & & & & & $7.3 \mathrm{E}-11$ & & & & & & & \\
\hline 151 & 2133 & FHE- 57 & Swipe sample analysis & Gross alpha & $1.4 \mathrm{E}-14$ & $1.0 \mathrm{E}-03$ & 12.8 & 0.41 & 8.1 & None & 1 & $1.4 \mathrm{E}-17$ & 1308 & E & $1.8 \mathrm{E}-15$ & 768 & SW & $4.5 E-15$ & 1 \\
\hline 151 & 2143 & FHE-63 & Transfer of standards for & H.3 & $3.6 \mathrm{E}-12$ & $1.0 \mathrm{E}-03$ & 12.8 & 0.41 & 8.2 & None & 1 & $3.6 E-15$ & 1308 & $E$ & $8.7 E-19$ & 768 & SW & $2.1 E-18$ & 1 \\
\hline & & & $\begin{array}{l}\text { the analysis of enviormmental } \\
\text { samples; analysis of standardas }\end{array}$ & 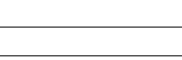 & & & & & & & & & & & & & & & \\
\hline & & & for environmental samples & & & & & & & & & & & & & & & & \\
\hline 151 & 2147 & FHE-67 & Transfer of yield tracers for & Pu-242 & 7.1E-13 & $\begin{array}{ll}1.0 \mathrm{E}-03 \\
\end{array}$ & 12.8 & 0.41 & 8.0 & None & 1 & 7.1E-16 & 1308 & $\mathrm{E}$ & $6.5 E-14$ & 768 & SW & $1.6 \mathrm{E}-13$ & 1 \\
\hline 151 & 2149 & FHE-78 & 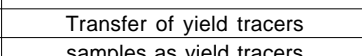 & Pu-238 & $2.0 E-14$ & $\begin{array}{ll}1.0 \mathrm{E}-03 \\
1.0-02\end{array}$ & 13.1 & 0.41 & 7.8 & None & 1 & $2.0 \mathrm{E}-17$ & 1308 & $\mathrm{E}$ & $6.0 E-13$ & 768 & SW & $1.5 E-12$ & 1 \\
\hline & & & $\begin{array}{l}\text { Sampless a yeled ricers } \\
\text { during analysis }\end{array}$ & 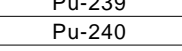 & $\begin{array}{l}4.0 E-14 \\
4.0 E-14\end{array}$ & $\begin{array}{l}\frac{1.0 E-03}{1.0 E-03} \\
\end{array}$ & & & & & & $\begin{array}{l}\frac{4.0 E-17}{4.0 E-17} \\
4.9\end{array}$ & & & & & & & \\
\hline & & & & $\begin{array}{l}\text { Pu-242 } \\
\text { U-232 }\end{array}$ & $\begin{array}{l}3.0 \mathrm{E}-12 \\
1.0 \mathrm{E}-12 \\
\mathrm{n}\end{array}$ & $\begin{array}{ll}1.0 \mathrm{E}-03 \\
1.0 \mathrm{E}-03\end{array}$ & & & & & & $\begin{array}{l}3.0 E-15 \\
100-15\end{array}$ & & & & & & & \\
\hline & & & & $\mathrm{U}-233$ & $9.0 E-13$ & $1.0 \mathrm{E}-03$ & & & & & & $9.0 E-16$ & & & & & & & 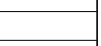 \\
\hline & & & & $\frac{-2.28}{0 s-134}$ & $\begin{array}{l}4.0 \mathrm{E}-15 \\
1.4 \mathrm{E}-12\end{array}$ & $\begin{array}{l}\frac{1.0 \mathrm{E}-03}{1.0 \mathrm{E}-03} \mathrm{r} \\
\end{array}$ & & & & & & $\begin{array}{l}4.0 E-18 \\
1.4 E-15\end{array}$ & & - & & & & & \\
\hline & & & & Cs-137 & $8.1 E-13$ & $1.0 \mathrm{E}-03$ & & & & & & $8.1 \mathrm{E}-16$ & & & & & & & \\
\hline 151 & $2302 \mathrm{~A}$ & FHE-9 & Waste treatability studies & $\mathrm{H}-3$ & $1.0 \mathrm{E}-04$ & $1.0 \mathrm{E}-03$ & 13.1 & 0.41 & 7.5 & None & 1 & $1.0 \mathrm{E}-07$ & 1308 & $E$ & $2.1 E-11$ & 768 & SW & $5.9 E-11$ & 1 \\
\hline & & & & 0.235 & $6.11-14$ & $1.0 \mathrm{E}=03 \mathrm{H}$ & & & & & & $6.1 E-17$ & & & & & & & \\
\hline 151 & 2308 & FHE-16 & Ceramics leaching studies & Pu-239 & $1.96-02$ & $\begin{array}{ll}1.0 \mathrm{E}-03 \\
1.0502\end{array}$ & 12.8 & 0.41 & 7.3 & Double HEPA & 0.0001 & $1.9 E-09$ & 1308 & E & $3.5 E-07$ & 768 & SW & $8.96-03$ & 1 \\
\hline & & & & $\begin{array}{l}\text { Pu-c204 } \\
\text { Pu-241 }\end{array}$ & $\begin{array}{l}4.4 \mathrm{E}-\mathrm{-} 3 \\
6.8 \mathrm{-02}\end{array}$ & $\begin{array}{l}1.0 E-03 \\
1.0 E-03 \\
\end{array}$ & & & +4 & & & 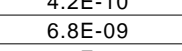 & & & & & & & - \\
\hline & & & & $\begin{array}{l}\text { Am-241 } \\
\text { Pu-2238 }\end{array}$ & $\begin{array}{l}\frac{1.1 \mathrm{E}-03}{5.6 \mathrm{E}-04} \\
5\end{array}$ & $\begin{array}{l}\frac{1.0 \mathrm{E}-03}{1.0 \mathrm{E}-03} \\
\end{array}$ & & & & & & $\begin{array}{l}\frac{1.1 \mathrm{E}-10}{5 \mathrm{E}-11} \\
5 \mathrm{E}-11\end{array}$ & & - & & & & & \\
\hline & & & & U-234 & $\begin{array}{l}2.2 E-07 \\
09750.9\end{array}$ & $\begin{array}{ll}1.0 \mathrm{E}-03 \\
\end{array}$ & & & & & & 2.2E-14 & & & & & & & 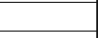 \\
\hline & & & & U-238 & $\begin{array}{l}2.1 \mathrm{E}-07 \\
2.07\end{array}$ & $\begin{array}{l}1.06-03 \\
1.0 E-03 \\
\end{array}$ & & & & & & 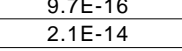 & & & & & & & 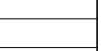 \\
\hline 151 & 2308 & FHE-12 & Ceramics leaching studies & U-234 & $6.6 \mathrm{E}-07$ & $1.0 \mathrm{E}-03$ & 13.1 & 0.41 & 7.8 & None & 1 & $6.6 \mathrm{E}-10$ & 1308 & $E$ & $5.9 E-08$ & 768 & SW & $1.4 \mathrm{E}-07$ & 1 \\
\hline & & & & $\begin{array}{l}U-235 \\
U-238 \\
\end{array}$ & $\begin{array}{l}\frac{2.9 E-08}{6.1 E-07} \\
6.07\end{array}$ & $\begin{array}{l}\frac{1.0 \mathrm{E}-03}{1.0 \mathrm{E}-03} \\
\end{array}$ & & & 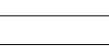 & & & $\begin{array}{l}2.9 E-11 \\
6.1 E-10\end{array}$ & & & & & & & \\
\hline 151 & 2312 & FHE-21 & Solubility studies & Np-237 & $2.7 \mathrm{E}-08$ & $1.0 \mathrm{E}-03$ & 12.8 & 0.41 & 7.6 & Double HEPA & 0.0001 & $2.7 \mathrm{E}-15$ & 1308 & $E$ & $4.9 E-13$ & 768 & SW & $1.2 \mathrm{E}-08$ & 1 \\
\hline 151 & 2312 & FHE-21 & Solubility studies & Np-237 & $6.4 E-09$ & $1.0 \mathrm{E}-03$ & 12.8 & 0.41 & 7.1 & None & 1 & $6.4 E-12$ & 1308 & $\mathrm{E}$ & $1.2 \mathrm{E}-09$ & 768 & SW & $3.0 E-09$ & 1 \\
\hline 151 & 2318 & FHE-22 & Transfer of sample solutions & Pu-242 & $1.9 \mathrm{E}-09$ & $1.0 \mathrm{E}-03$ & 9.8 & 0.41 & 8.0 & Double HEPA & 0.0001 & $1.9 E-16$ & 1308 & $\mathrm{E}$ & $2.5 E-14$ & 768 & 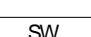 & $78 E-10$ & 1 \\
\hline 151 & 2322 & FHE-38 & 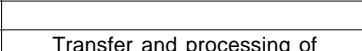 & 5 & 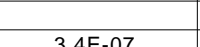 & $10=03$ & +12 & 0 & 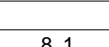 & None & -1 & ( & 2 & E & $56 \mathrm{~F}-0$ & 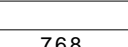 & -1 & $14 \mathrm{E}$ & 5 \\
\hline in & 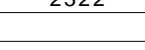 & méso & 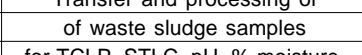 & co.60 & $\begin{array}{l}.04-76-08 \\
\end{array}$ & $\begin{array}{l}1.00-03 \\
1.0 E-03\end{array}$ & 12.0 & 0.41 & 8.1 & Nonte & 1 & 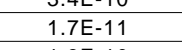 & 1308 & $E$ & 5.6E-09 & 768 & Sw & 1.44-0. 38 & \\
\hline & & & $\begin{array}{l}\text { for TCLP, TSLC, PH, \% mosisture, } \\
\text { TTLC analyses }\end{array}$ & $\begin{array}{l}\text { Sh-90 } \\
\text { Th-228 } \\
\end{array}$ & $\frac{1.88-07}{1.3 \mathrm{E}-11}$ & $\begin{array}{l}\frac{1.0 \mathrm{E}-03}{1.0 \mathrm{E}-03} \\
\end{array}$ & & & & & & $\begin{array}{l}\frac{1.8 \mathrm{EE}-10}{1.3 \mathrm{E}-14} \\
\end{array}$ & & & & & & & \\
\hline & & & & $\begin{array}{l}\text { Th-230 } \\
\text { Th-232 }\end{array}$ & $\begin{array}{l}3.9 \mathrm{E}-11 \\
2.8 \mathrm{E}-12\end{array}$ & $\begin{array}{l}\frac{1.0 \mathrm{E}-03}{1.0 \mathrm{E}-03} \\
-1\end{array}$ & & & & & & $\begin{array}{l}3.9 \mathrm{E}-14 \\
2.8 \mathrm{E}-15\end{array}$ & & & & & & & \\
\hline & & & & Pu-238 & $3.9 \mathrm{E}-10$ & $\begin{array}{l}1.0 \mathrm{E}-03 \\
1.03\end{array}$ & & & & & & $3.9 E-13$ & & & & & & & \\
\hline & & & & $\begin{array}{l}\text { Pu-2399 } \\
\text { Pu-240 }\end{array}$ & $\begin{array}{l}1.8 E-08 \\
1.1 E-08\end{array}$ & $\begin{array}{l}\frac{1.0 \mathrm{E}-03}{1.0 \mathrm{E}-03} \\
\end{array}$ & & & & & & $\frac{1.8 \mathrm{E}-11}{1.1 \mathrm{E}-11}$ & & & & & & & \\
\hline & & & & Pu-241 & $9.4 E-09$ & $\begin{array}{ll}1.0 \mathrm{E}-03 \\
.0-02\end{array}$ & & & & & & $9.4 E-12$ & & & & & & & \\
\hline & & & & $U-234$ & $2.6 \mathrm{E}-10$ & $\begin{array}{l}1.0 \mathrm{E}-03 \\
\end{array}$ & & & & & & $2.6 E-13$ & & & & & & & E \\
\hline & & & & & $\frac{1.5 \mathrm{E}}{4.7 \mathrm{E}}$ & $\begin{array}{l}1.0 E-03 \\
1.0 E-03\end{array}$ & & & & & & $\begin{array}{l}1.5-5-14 \\
4.7-14\end{array}$ & & & & & & & \\
\hline & & & & Gross alpha & $\begin{array}{l}9.0 E-09 \\
21=10\end{array}$ & $\begin{array}{ll}1.0 E-03 \\
1.0502\end{array}$ & & & & & & $9.0 \mathrm{E}-12$ & & & & & & & \\
\hline & & & & $\begin{array}{ll}\text { Gross } \\
H-3\end{array}$ & $\begin{array}{l}2.1 .1-10 \\
2.11-08\end{array}$ & $\begin{array}{l}1.0 E-03 \\
1.0 E-03 \\
\end{array}$ & & & & & & $\frac{1.1 E-13}{2.1 E-11}$ & & & & & & & \\
\hline 151 & 2326 & FHE-39 & Chemical analysis of waste & Cs-137 & $3.8 \mathrm{E}-07$ & $1.0 E+00$ & 12.8 & 0.41 & 7.6 & None & 1 & $3.8 \mathrm{E}-07$ & 1308 & E & $8.8 E-06$ & 768 & SW & $2.2 \mathrm{E}-05$ & 1 \\
\hline & & & & 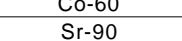 & $\begin{array}{l}1.8 \mathrm{E}-0.88 \\
2.0 \mathrm{E}-07\end{array}$ & $\begin{array}{l}1.0 E+00 \\
1.0 E+00\end{array}$ & & & & & & 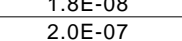 & & & & & & & \\
\hline & & & & Th-228 & $1.5 E-11$ & $1.0 \mathrm{E}+00$ & & & & & & $\begin{array}{l}1.5 \mathrm{E}-1 \\
\end{array}$ & & & & & & & \\
\hline & & & & Th-230 & & $1.0 E+00$ & & & & & & & & & & & & & \\
\hline
\end{tabular}


Attachment 1 - 2000 LLNL NESHAPs Annual Report Spreadsheet

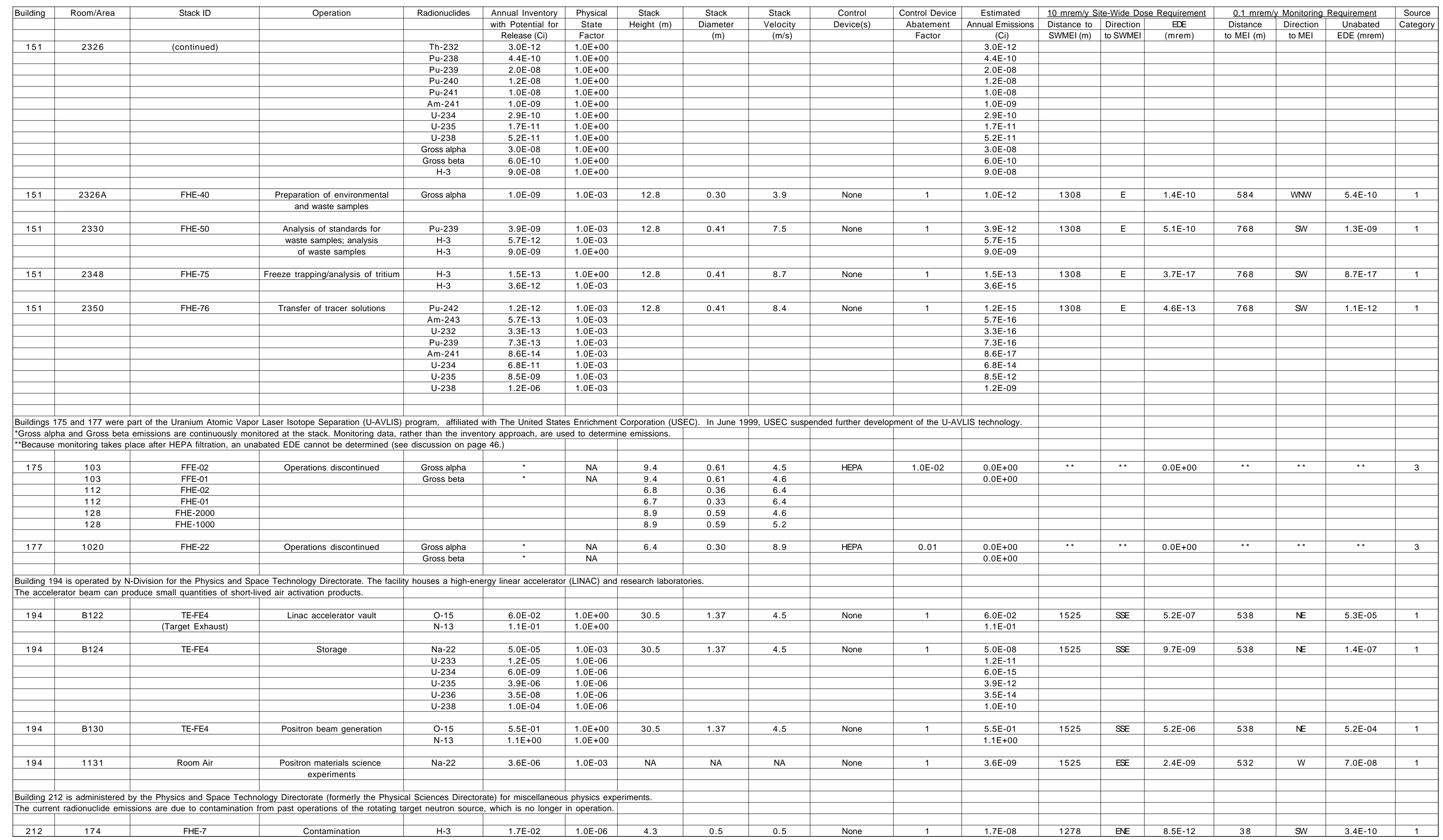


Attachment 1 - 2000 LLNL NESHAPs Annual Report Spreadsheet

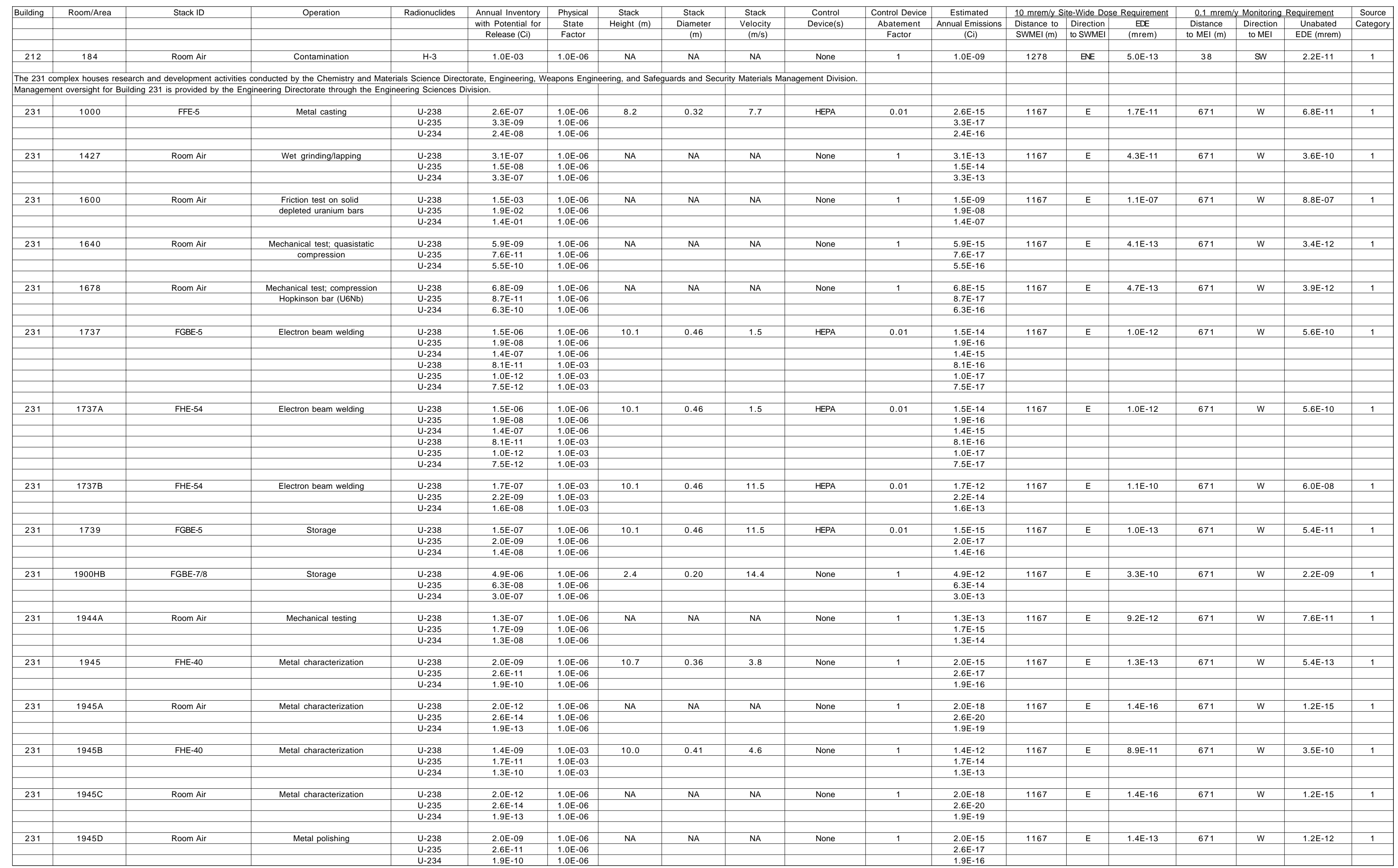


Attachment 1 - 2000 LLNL NESHAPs Annual Report Spreadsheet

\begin{tabular}{|c|c|c|c|c|c|c|c|c|c|c|c|c|c|c|c|c|c|c|c|}
\hline \multirow[t]{2}{*}{ Building } & \multirow[t]{2}{*}{ Room/Area } & \multirow[t]{2}{*}{ Stack ID } & \multirow[t]{2}{*}{ Operation } & \multirow[t]{2}{*}{ Radionuclides } & \multirow{2}{*}{$\begin{array}{c}\text { Annual Inventory } \\
\text { with Potential for } \\
\text { Release (Ci) }\end{array}$} & \multirow{2}{*}{$\begin{array}{l}\text { Physical } \\
\text { State } \\
\text { Factor }\end{array}$} & \multirow{2}{*}{$\begin{array}{l}\text { Stack } \\
\text { Height (m) } \\
\end{array}$} & \multirow{2}{*}{$\begin{array}{c}\text { Stack } \\
\text { Diameter } \\
(\mathrm{m}) \\
\end{array}$} & \multirow{2}{*}{$\begin{array}{l}\text { Stack } \\
\begin{array}{c}\text { Selocity } \\
(\mathrm{m} / \mathrm{s})\end{array} \\
\end{array}$} & \multirow{2}{*}{$\begin{array}{c}\text { Controlol } \\
\text { Device(s) }\end{array}$} & \multirow{2}{*}{$\begin{array}{l}\frac{C_{\text {Control Device }}}{\text { Abatement }} \\
\text { Aactor }\end{array}$} & \multirow{2}{*}{$\begin{array}{l}\text { Estimated } \\
\text { Annual Emissions } \\
\text { (Ci) }\end{array}$} & \multicolumn{3}{|c|}{$\frac{10 \mathrm{mrem} / \mathrm{s} \text { Site-Wide Dose Requirement }}{\text { Distane }}$} & \multicolumn{3}{|c|}{ 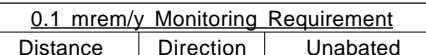 } & \multirow{2}{*}{$\begin{array}{l}\text { Source } \\
\text { Category } \\
\end{array}$} \\
\hline & & & & & & & & & & & & & $\begin{array}{l}\text { Distance to } \\
\text { SwMEI(m) }\end{array}$ & $\begin{array}{l}\text { Diriction } \\
\text { to swWEI }\end{array}$ & $\begin{array}{l}\text { EDE } \\
\text { (mrem) }\end{array}$ & $\begin{array}{l}\text { Distance } \\
\text { to MEI (m) }\end{array}$ & $\begin{array}{l}\text { Diriection } \\
\text { to MEI }\end{array}$ & $\begin{array}{l}\text { Unabated } \\
\text { EDE (mrem) }\end{array}$ & \\
\hline 231 & $1945 \mathrm{E}$ & Room Air & Wet grinding/polishing & U-238 & $2.0 \mathrm{E}-06$ & $1.0 \mathrm{E}-03$ & NA & NA & NA & None & 1 & $2.0 E-09$ & 1167 & E & $1.4 \mathrm{E}-07$ & 671 & w & $1.2 \mathrm{E}-06$ & 1 \\
\hline & & & & $\begin{array}{l}\mathrm{U}-235 \\
-234\end{array}$ & $\begin{array}{l}2.66-88 \\
1.9 E-07\end{array}$ & $\begin{array}{l}\frac{1.0 E-03}{1.0 E-03} \\
1.03\end{array}$ & & & & & & $\begin{array}{l}2.6 \mathrm{E}-11 \\
1.9 \mathrm{E}-10\end{array}$ & & & & & & & \\
\hline \multirow{2}{*}{$\begin{array}{l}\text { Building } 2 \\
\text { Most of the }\end{array}$} & is part of the & Emistry and Materials Sciences & Directorate. Operations in the facility & nnclude examinatic & of material structure & 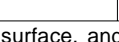 & subsurface; pr & ision cutting, ic & molanting, at & metalluraical studies & & & & & & & & & \\
\hline & depleted uraniu & in this building is used for cha & erization studuies; some is used for & On beam implantal & experiments. & surace, anic & subsuriace, pi & . & mplatumg, al & . & & & & & & & & & \\
\hline 235 & 1122 & 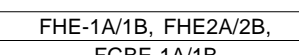 & Surface analysis & U-234 & $1.5 \mathrm{E}-11$ & $1.0 \mathrm{E}-06$ & 10.7 & 2.75 & 4.0 & None & 1 & $1.5 \mathrm{E}-17$ & 1065 & $\mathrm{ENE}$ & $1.3 \mathrm{E}-14$ & 556 & sw & $1.3 \mathrm{E}-14$ & 1 \\
\hline & & & & $\begin{array}{l}0-233 \\
-238 \\
\end{array}$ & $\begin{array}{l}\frac{2.16-12}{1.6 E-10} \\
10\end{array}$ & $\begin{array}{l}1.0 \mathrm{E}-\mathrm{-}-06 \\
1.06-06\end{array}$ & & & & & & 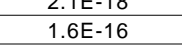 & & & & & & & \\
\hline 235 & 1130 & $\begin{array}{l}\text { FHE-1A/B, FHE2A/2B, } \\
\text { EGBE }\end{array}$ & 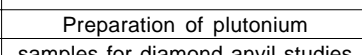 & Pu-239 & $\frac{1.2 \mathrm{E}-06}{2.06}$ & $\frac{1.0 E+00}{1.05}$ & 10.7 & 2.75 & 4.0 & Double HEPA & 0.0001 & $\frac{1.2 E-10}{25}$ & 1065 & ENE & $3.7 E^{-08}$ & 556 & sw & $3.9 E-04$ & 1 \\
\hline & & FGBE-1A $1 B$ & samples for diamond anvil studies & $\begin{array}{ll}\text { Put-240 } \\
\text { Am-241 }\end{array}$ & $\begin{array}{l}2.7 \mathrm{E}-07 \\
1.5 \mathrm{E}-07 \\
\end{array}$ & $\begin{array}{l}\frac{1.0 E+00}{1.0 E+00} \\
1.00\end{array}$ & & & & & & $\begin{array}{l}2.7 \mathrm{E}-11 \\
1.5 \mathrm{E}-11 \\
\end{array}$ & & & & & & & \\
\hline & & & & $\begin{array}{l}P u-241 \\
\text { Puu-242 }\end{array}$ & $\begin{array}{l}3.1 E-06 \\
.8 E-11 \\
\end{array}$ & $\begin{array}{l}\frac{1.0 E++00}{1.0 E+00} \\
1.00\end{array}$ & & & & & & $\begin{array}{l}3.1 \mathrm{E}-10 \\
1.8 \mathrm{E}-15\end{array}$ & & & & & & & \\
\hline & & & & $\begin{array}{l}\text { Pu-238 } \\
\text { Puu-239 }\end{array}$ & $3.22-08$ & $\frac{1.0 E+00}{1.0 E-03}$ & & & & & & $\begin{array}{l}3.2-12 \\
27-13 \\
\end{array}$ & & & & & & & \\
\hline & & & & $\begin{array}{ll}\text { Pu-240 } \\
\text { Am-241 }\end{array}$ & $\begin{array}{l}6.1 E-07 \\
35-07\end{array}$ & $\begin{array}{l}1.0 E-03 \\
1.0 E-03 \\
10=03\end{array}$ & & & & & & 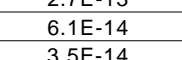 & & & & & & & \\
\hline & & & & $\begin{array}{lll}\text { Put-241 } \\
\text { Put.2013 }\end{array}$ & $\begin{array}{l}7.0 E-06 \\
.05 .011\end{array}$ & $\begin{array}{l}1.0 \mathrm{E}-03 \\
1.0502\end{array}$ & & & & & & $\begin{array}{l}3.5 E-14 \\
7.0 E-13 \\
.0518\end{array}$ & & & & & & & \\
\hline & & & & Pu-238 & 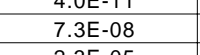 & $\begin{array}{l}1.0 \mathrm{E}-03 \\
1.0 \mathrm{C}-03 \\
\end{array}$ & & & & & & 年.0E-18 & & & & & & & \\
\hline & 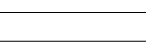 & & & Pu-240 & $\begin{array}{l}2.25-05 \\
5.3 E-06\end{array}$ & $\begin{array}{l}1.0 \mathrm{E}-06 \\
1.06\end{array}$ & & & & 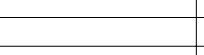 & & $\begin{array}{l}2.3 \mathrm{E}-15 \\
5.3 \mathrm{E}-16\end{array}$ & & & & & & & \\
\hline & & & & $\begin{array}{l}\text { Am-241 } \\
\text { Pu-2241 }\end{array}$ & $\begin{array}{l}3.0 \mathrm{O}-0.6 \\
66 \mathrm{E}-05\end{array}$ & $\begin{array}{l}1.0 E-06 \\
10 E-06\end{array}$ & & & & & & $\begin{array}{l}3.0 E-16 \\
6.1 E-15\end{array}$ & & & & & & & \\
\hline & - & -5 & 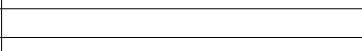 & Pu-242 & $3.5 \mathrm{E}-10$ & $1.0 \mathrm{E}-06$ & & & & & & $3.5 \mathrm{E}-20$ & & & & & & & \\
\hline 025 & & & -5 & & $6.3 E=-0 r$ & 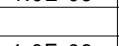 & 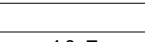 & & & & & t & & & & & & & \\
\hline 200 & 1131 & $\begin{array}{l}\text { HDLH-, } / \\
\text { (FHE-1A/1B, FHE2A/2B, }\end{array}$ & Melalolograpinc sammile & $\begin{array}{l}-0.234 \\
-235 \\
\end{array}$ & $\frac{1.11-0.8}{1.5 E-09}$ & $\frac{1.0 E-06}{1.0 E-06}$ & 10.7 & 2.75 & 4.0 & HEPA & 0.01 & $\frac{1.1 E-16}{1.5 E-17}$ & 1065 & $\mathrm{ENE}$ & $9.2 \mathrm{E}-14$ & 556 & sw & $9.6 \mathrm{E}-12$ & 1 \\
\hline & & FGBE-1A/B) & & U-238 & $1.2 \mathrm{E}-07$ & $1.0 \mathrm{E}-06$ & & & & & & $1.2 \mathrm{E}-15$ & & & & & & & \\
\hline 235 & 1133 & 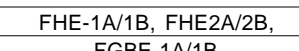 & Microstructure examination & U-234 & $2.8 \mathrm{E}-09$ & $1.0 \mathrm{E}-06$ & 10.7 & 2.75 & 4.0 & None & 1 & $2.8 \mathrm{E}-15$ & 1065 & ENE & $2.3 \mathrm{E}-12$ & 556 & SW & $2.4 \mathrm{E}-12$ & 1 \\
\hline & & & & U-238 & $3.0 E-08$ & $1.0 \mathrm{E}-06$ & & & & & & $3.0 E-14$ & & & & & & & \\
\hline 235 & 1235 & FHE-1A/1B, FHE2A/2B, & $X$-ray diffraction of & $\mathrm{U}-234$ & $1.1 \mathrm{E}-09$ & $1.0 \mathrm{E}-06$ & 10.7 & 2.75 & 14.3 & None & 1 & $1.1 \mathrm{E}-15$ & 1065 & $\mathrm{ENE}$ & $1.5 E-13$ & 556 & SW & $1.6 \mathrm{E}-13$ & 1 \\
\hline & & FGBE-1A/1B & uranium oxide ceramics & $\frac{\mathrm{U}-235}{\mathrm{U}-238}$ & $9.9 E-10$ & $\begin{array}{l}\frac{1.0 \mathrm{E}-06}{1.0 \mathrm{E}-06} \\
-\end{array}$ & & & & & & $\begin{array}{l}4.6 \mathrm{E}-17 \\
9.9 \mathrm{E}-16\end{array}$ & & & & & & & \\
\hline Bulding : 2 & is administere & $y$ the Chemistry and Material & iences Directorate for material prope & ies research and & ting, and for study $\mathrm{c}$ & soil bacterit & & & & & & & & & & & & & 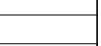 \\
\hline 241 & 1616 & Room Air & Paritcle size analysis of powders & $u-238$ & $2.0 \mathrm{E}-11$ & $1.0 \mathrm{E}-03$ & NA & NA & NA & None & 1 & $2.0 E-14$ & 1140 & E & $2.9 \mathrm{E}-12$ & 697 & w & $2.2 E-11$ & 1 \\
\hline & & & & $\begin{array}{l}u-235 \\
U-234 \\
\end{array}$ & $\begin{array}{l}\frac{3.3 E-13}{2.1 E-11} \\
2.11\end{array}$ & 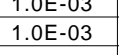 & & & & & & $\begin{array}{l}\frac{3.3 E-16}{2.1 E-14} \\
2.14\end{array}$ & & & & & & & \\
\hline 241 & 1678 & FHE- 55 & Research and development & U-238 & $\begin{array}{l}1.4 \mathrm{E}-05 \\
.7-0.57\end{array}$ & $1.0 E+00$ & 7.9 & 0.28 & 15.4 & HEPA & 0.01 & $1.4 \mathrm{E}-07$ & 1140 & E & $1.8 \mathrm{E}-05$ & 821 & SW & 4.4E-03 & 1 \\
\hline & & & immobilization using uranium oxide & $u-234$ & $\begin{array}{l}0.1 .5-1 \\
1.5-05 \\
0.05\end{array}$ & $\begin{array}{l}1.0 E+00 \\
1.0 E+00\end{array}$ & & & & & & 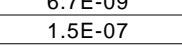 & & & & & & & \\
\hline & & & & $\frac{U-238}{U U-235}$ & $\begin{array}{l}9.4 E-07 \\
4.4-0.8\end{array}$ & $\begin{array}{l}1.0 \mathrm{E}-03 \\
1.0 \mathrm{E}-03\end{array}$ & & & & & & $\begin{array}{l}9.4 E-12 \\
4-12=13\end{array}$ & & & & & & & \\
\hline & & & & $\begin{array}{l}u-235 \\
U-234\end{array}$ & $\begin{array}{l}4.4 E=-08 \\
1.05-06\end{array}-35$ & $\begin{array}{l}1.0 E-03 \\
1.0 E-03 \\
\end{array}$ & & & & & & $\begin{array}{l}4.4 \mathrm{E}-13 \\
1.0 \mathrm{E}-11\end{array}$ & & & & & & & \\
\hline & & & & $\begin{array}{l}-2.28 \\
1.235 \\
\end{array}$ & $\begin{array}{l}1.9 E-07 \\
88-09\end{array}$ & 1.0E-06 10.06 & & & & & & $\begin{array}{l}1.96-15 \\
88.517\end{array}$ & & & & & & & \\
\hline & & & & U-234 & $2.0 E-07$ & $1.0 \mathrm{E}-06$ & & & & & & $\begin{array}{l}2.0 \mathrm{E}-15 \\
2.00\end{array}$ & & & & & & & \\
\hline 241 & 1838 & FGBE-10 & Pressing and sintering of & U-238 & $8.9 E-07$ & $1.0 E+00$ & 7.6 & 0.15 & 12.9 & HEPA & 0.01 & $8.9 \mathrm{E}-09$ & 1140 & E & $1.2 \mathrm{E}-06$ & 697 & w & $5.9 \mathrm{E}-04$ & 1 \\
\hline & & & & $\begin{array}{l}U-235 \\
U-234\end{array}$ & $\begin{array}{l}4.2 \mathrm{E}-08 \\
9.6 \mathrm{E}-01\end{array}$ & $\begin{array}{l}1.0 E+00 \\
1.0 E+00\end{array}$ & & & & & & $\begin{array}{l}4.2 \mathrm{E}-10 \\
9.6 \mathrm{E}-03\end{array}$ & & & & & & & \\
\hline & & & & $\frac{U-238}{0-235}$ & $\begin{array}{l}2.0 E-10 \\
9.5 E-12\end{array}$ & $\begin{array}{l}\frac{1.0 \mathrm{E}-03}{1.0 \mathrm{E}-03} \\
\end{array}$ & & & & & & $\frac{2.05-15}{95-17}$ & & & & & & & \\
\hline & & & & $\begin{array}{l}\mathrm{U}-234 \\
\mathrm{u}\end{array}$ & $2.2 \mathrm{E}-10$ & $1.0 E-03$ & & & & & & $2.2 \mathrm{E}-15$ & & & & & & & 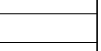 \\
\hline & & & & $\begin{array}{ll}-2-288 \\
U-235\end{array}$ & & & & & & & & & & & & & & & \\
\hline & & & & U-234 & 1.1E-14 & $1.0 \mathrm{E}-06$ & & & & & & 1.1E-22 & & & & & & & \\
\hline 241 & 1838 & FHE-7 & ig and measuring of & U-238 & 4.6 & $1.0 E+00$ & 7.9 & 0.39 & 6.6 & None & 0.01 & $4.6 \mathrm{E}$ & 1140 & $E$ & 6.4E-07 & 697 & w & $2.5 \mathrm{E}-04$ & 1 \\
\hline & & & sintered uranium oxide disks & U-235 & $2.2 E-08$ & $1.0 E+00$ & & & & & & & & & & & & & - \\
\hline & & & & $\begin{array}{lll}0-234 \\
U\end{array}$ & 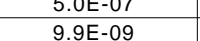 & $\begin{array}{l}1.0 E+00 \\
1.0 \mathrm{E}-03\end{array}$ & & & & & & 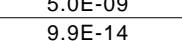 & & & & & & & \\
\hline & & & & $0-235$ & & & & & & & & & & & & & & & \\
\hline & & & & U-234 & 1.1E-08 & $1.0 \mathrm{E}-03$ & & & & & & $1.1 \mathrm{E}$ & & & & & & & \\
\hline
\end{tabular}


Attachment 1 - 2000 LLNL NESHAPs Annual Report Spreadsheet

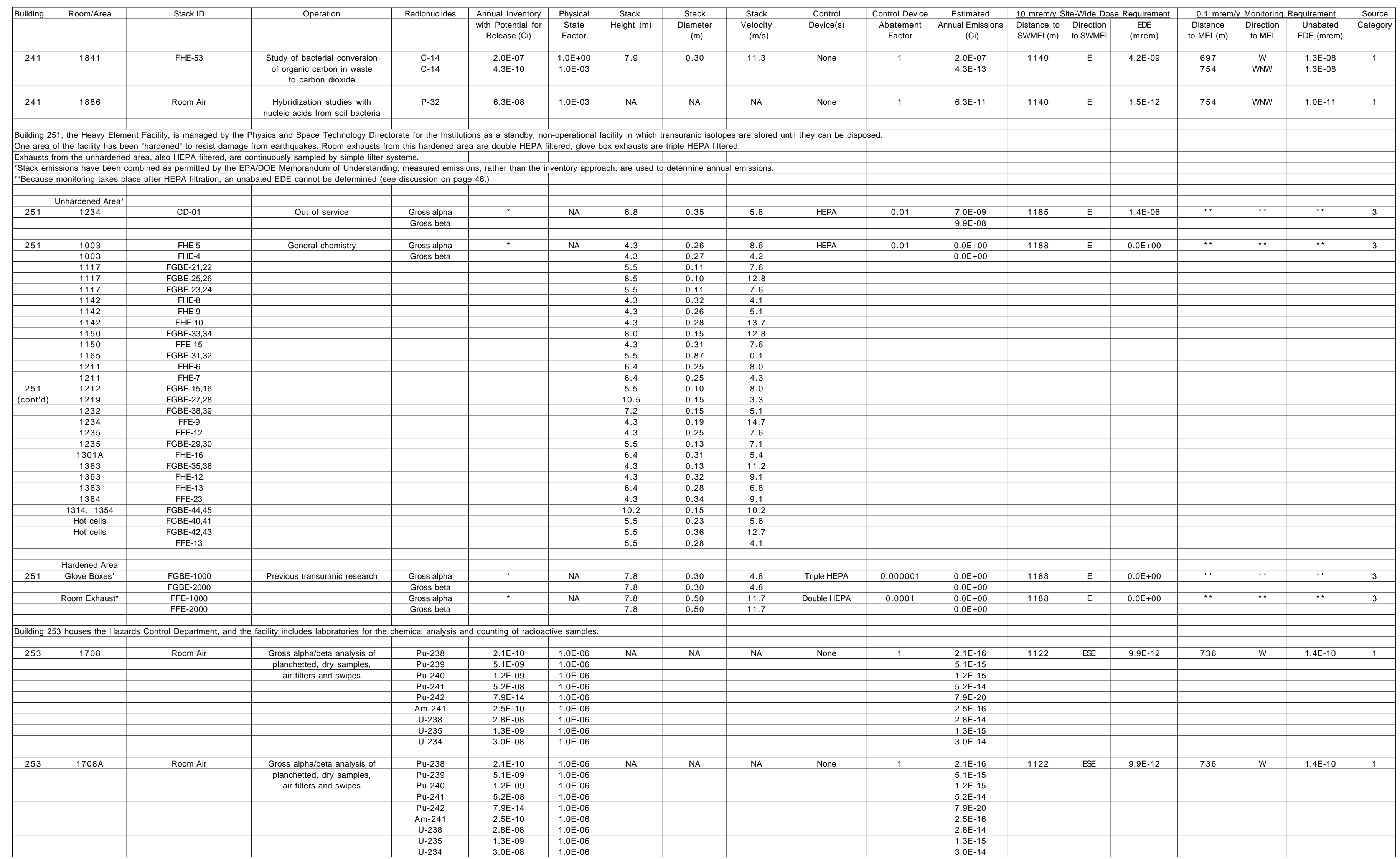


Attachment 1 - 2000 LLNL NESHAPs Annual Report Spreadsheet

\begin{tabular}{|c|c|c|c|c|c|c|c|c|c|c|c|c|c|c|c|c|c|c|c|}
\hline \multirow[t]{2}{*}{ Building } & \multirow[t]{2}{*}{ Room/Area } & \multirow[t]{2}{*}{ Stack ID } & \multirow[t]{2}{*}{ Operation } & \multirow[t]{2}{*}{ Radionuclides } & \multirow{2}{*}{$\begin{array}{l}\text { Annual Inventory } \\
\text { with Potential for } \\
\text { Release (Ci) }\end{array}$} & \multirow{2}{*}{$\begin{array}{l}\text { Physical } \\
\text { State } \\
\text { Factor }\end{array}$} & \multirow{2}{*}{$\begin{array}{l}\text { Stack } \\
\text { Height (m) } \\
\end{array}$} & \multirow{2}{*}{$\begin{array}{c}\text { Stack } \\
\text { Diameter } \\
(\mathrm{m})\end{array}$} & \multirow{2}{*}{$\begin{array}{c}\text { Stack } \\
\text { Velocity } \\
(\mathrm{m} / \mathrm{s})\end{array}$} & \multirow{2}{*}{$\begin{array}{l}\text { Control } \\
\text { Device(s) }\end{array}$} & \multirow{2}{*}{$\begin{array}{c}\text { Control Device } \\
\text { Abatement } \\
\text { Factor }\end{array}$} & \multirow{2}{*}{$\begin{array}{l}\text { Estimated } \\
\text { Annual Emissions } \\
\text { (Ci) }\end{array}$} & \multicolumn{3}{|c|}{$10 \mathrm{mrem} / \mathrm{y}$ Site-Wide Dose Reauirement } & \multicolumn{3}{|c|}{ 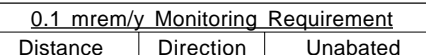 } & \multirow{2}{*}{$\begin{array}{l}\text { Source } \\
\text { Category } \\
\end{array}$} \\
\hline & & & & & & & & & & & & & $\begin{array}{l}\text { Distance to } \\
\text { SWMEI (m) }\end{array}$ & $\begin{array}{l}\text { Diriction } \\
\text { to swWEI }\end{array}$ & $\begin{array}{c}D E \\
(m r e m) \\
\end{array}$ & 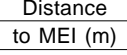 & $\begin{array}{l}\text { Pieretion } \\
\text { to MEI }\end{array}$ & $\begin{array}{l}\text { Unabated } \\
\text { EDE (mrem) }\end{array}$ & \\
\hline 253 & $1708 \mathrm{~B}$ & Room Air & Gross alphabeta analysis of & Pu-238 & $2.1 \mathrm{E}-10$ & $1.0 \mathrm{E}-06$ & NA & NA & NA & None & 1 & $2.1 \mathrm{E}-16$ & 1122 & ESE & $9.9 E-12$ & 736 & w & $1.4 \mathrm{E}-10$ & 1 \\
\hline & & & air filters and swipes & Pu-240 & 1.25-099 1909 & $\begin{array}{l}1.0 E-00 \\
1.0 E-06\end{array}$ & 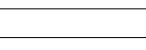 & & & & & $\begin{array}{l}3.15-15 \\
1.2 E-15 \\
\end{array}$ & -4 & & & 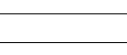 & & & \\
\hline & & & & $\begin{array}{l}\text { Pu-241 } \\
\text { Pu-242 }\end{array}$ & 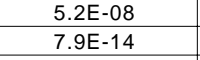 & $\begin{aligned} \frac{1.0 E-06}{1.0 E-06} \\
\end{aligned}$ & & & & & & $\begin{array}{l}5.5 E-14 \\
7.9 E-20 \\
\end{array}$ & & & & & & & \\
\hline 253 & $1708 \mathrm{~B}$ & (continued) & & $\frac{A \mathrm{Am}-241}{\mathrm{U}-238}$ & $\begin{array}{l}2.5 \mathrm{E}-10 \\
2.8 \mathrm{-}-08 \\
\end{array}$ & $\begin{array}{l}\frac{1.0 E-06}{1.0 E-06} \\
\end{array}$ & & & & & & $\begin{array}{l}2.5 E-16 \\
2.8 E-14 \\
\end{array}$ & & & & & & & \\
\hline & & & & $\frac{U-235}{U-234}$ & $\begin{array}{r}\frac{1.3 E-09}{3.0 E-08} \\
3\end{array}$ & $\begin{array}{l}\frac{1.0 E-06}{1.0 E-06} \\
\end{array}$ & & & & & & 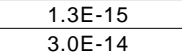 & & & & & & & \\
\hline 253 & 1732 & FHE-21 & Flaming gross alphabeta planchets & Pu-239 & $1.3 \mathrm{E}-13$ & $1.0 \mathrm{E}+00$ & 6.4 & 0.30 & 13.2 & None & 1 & $1.3 \mathrm{E}-13$ & 1122 & ESE & 2.1E-11 & 736 & $\mathrm{w}$ & 1.4E-10 & 1 \\
\hline & & & & $\begin{array}{l}\text { Giross sipha } \\
\text { Girss beta }\end{array}$ & $\begin{array}{l}1.22-13 \\
2.3 E-13 \\
\end{array}-13$ & $\begin{array}{l}\frac{1.0 E++00}{1.0 E+00} \\
1.00\end{array}$ & & 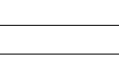 & & & & $\begin{array}{l}\frac{1.2 E-13}{2.3 E-13} \\
2.13\end{array}$ & & & & 798 & wnw & 1.4E-10 & \\
\hline & & & & & 1.1EE-12 & $1.0 E+00$ & & & & & & 1.1.1E-T2 25 & & & & & & & \\
\hline 203 & $11 / 34$ & Hoom Air & $\begin{array}{l}\text { Distillation of environmental } \\
\text { samples }\end{array}$ & $\begin{array}{l}\text { G-3 } \\
\text { Gross alpha }\end{array}$ & $\begin{array}{l}6.7 E-10 \\
5.4-14 \\
5-14\end{array}-5$ & $\frac{1.0 \mathrm{E}+00}{1.0 \mathrm{E}+00}$ & NA & NA & NA & None & 1 & 6.7-7E-10 & 1122 & ESE & $5.6 E-12$ & 736 & w & $7.8 E-11$ & 1 \\
\hline & & & & Gross beta & $4.1 E-13$ & $1.0 \mathrm{E}+00$ & & & & & & $4.1 E-13$ & & & & & & & \\
\hline 253 & 1734 & FGBE-1,2 & Sieve soil samples & $\begin{array}{l}\text { Gross alpha } \\
\text { Gross beta }\end{array}$ & $\begin{array}{l}2.7 \mathrm{E}-10 \\
4.6 \mathrm{E}-10\end{array}$ & $\begin{array}{l}\frac{1.0 E-06}{1.0 E-06} \\
-10\end{array}$ & 6.1 & 0.10 & 23.6 & HEPA & 0.01 & $\begin{array}{l}2.7 E-18 \\
.6 E-18\end{array}$ & 1122 & ESE & $2.5 \mathrm{E}-16$ & 736 & w & $2.4 E-13$ & 1 \\
\hline 253 & 1734 & FHE-13 & Samples and standards plating & $\begin{array}{l}\text { Gross alpha } \\
\text { Gross beta }\end{array}$ & $\begin{array}{l}\frac{1.7 E-11}{2.2 E-12} \\
\end{array}$ & $\begin{array}{l}\frac{1.0 \mathrm{E}+00}{1.0 \mathrm{E}+00} \\
\frac{1}{1}\end{array}$ & 10.4 & 0.30 & 12.3 & None & 1 & $\begin{array}{l}\frac{1.7 E-11}{2.2 E-12} \\
2 .\end{array}$ & 1122 & ESE & $9.2 E-11$ & 798 & wNW & $4.6 E-10$ & 1 \\
\hline & & & & $\begin{array}{c}H-3-3 \\
S r-90 / Y-90\end{array}$ & $\begin{array}{l}\frac{1.2 E-11}{1.7 E-12} \\
1.2\end{array}$ & $\begin{array}{l}\frac{1.0 \mathrm{E}+00}{1.0 \mathrm{E}+00} \\
\end{array}$ & & & & & & $\frac{1.2 \mathrm{E}-11}{1.7 \mathrm{E}-12}$ & & & & & & & \\
\hline & & & & Pu-239 & 7.8E-13 & $1.0 \mathrm{E}+00$ & & & & & & 7.8E-13 & & & & & & & \\
\hline 253 & 1734 & FHE-20 & Quality control sample & Pu-239 & $2.5 E-12$ & $1.0 \mathrm{E}-03$ & 10.4 & 0.30 & 12.3 & None & 1 & $2.5 E-15$ & 1122 & EEE & $1.8 \mathrm{E}-13$ & 798 & wNw & $9.2 E-13$ & 1 \\
\hline & & & aliquoting & 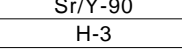 & $\begin{array}{l}2.2 E-12 \\
1.1 E-10\end{array}$ & $\begin{array}{l}\frac{1.0 E-03}{1.0 E-03} \\
\end{array}$ & & & & & & $\begin{array}{l}2.2 \mathrm{E}-15 \\
1.1 \mathrm{E}-13 \\
\end{array}$ & & & & & & & \\
\hline 253 & 1734 & FHE-11 & Acid digestion for & $\mathrm{H}-3$ & $6.8 E-09$ & $1.0 \mathrm{E}+00$ & 10.4 & 0.30 & 12.3 & None & 1 & $6.8 \mathrm{E}-09$ & 1122 & ESE & $2.8 E-09$ & 798 & WNW & 1.4E-08 $>2>0$ & 1 \\
\hline & & & sample analysis & Gross alpha & $\begin{array}{l}3.4 E-11 \\
-25=11\end{array}$ & $1.0 \mathrm{E}+00$ & & & & & & $\begin{array}{l}3.4 E-11 \\
.25=10\end{array}$ & & & & 736 & w & $1.4 E-08$ & \\
\hline & & & & $\begin{array}{l}\text { Gross beta } \\
\text { Sr/Y-90 }\end{array}$ & 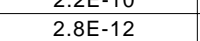 & 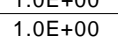 & & & & & & 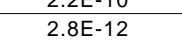 & & & & & & & \\
\hline & & & & Pu-239 & $3.1 E-12$ & $1.0 \mathrm{E}+00$ & & & & & & $3.1 \mathrm{E}-12$ & & & & & & & \\
\hline 253 & 1910 & FHE-22 & $\begin{array}{l}\text { Preparations of calibration } \\
\text { standards }\end{array}$ & $\begin{array}{ll}\mathrm{H}-3 \\
\mathrm{C}-14\end{array}$ & $\begin{array}{l}3.0 E-11 \\
1.5 E-11\end{array}$ & $\begin{array}{l}1.0 \mathrm{E}-03 \\
10 \mathrm{E}-03\end{array}$ & 7.0 & 0.20 & 5.2 & None & 1 & $\begin{array}{l}3.0 E-14 \\
1.5 E-14\end{array}$ & 1122 & ESE & $1.8 E-15$ & 736 & w & $2.1 E-14$ & 1 \\
\hline & & & standards & $\frac{C-14}{P-32}$ & $\begin{array}{l}\frac{1.5 E-11}{1.5 E-10} \\
\end{array}$ & $\begin{array}{l}\frac{1.0 E-03}{1.0 E-03} \\
\end{array}$ & & & & & & $\begin{array}{l}\frac{1.5 E-14}{1.5 \mathrm{E}-13} \\
\end{array}$ & & & & & & & \\
\hline & & & & & & & & & & & & & & & & & & & \\
\hline Building 2 & 4 is run by Haza & is Control for the purpose of co & ducting bioassayss and providing analy & tical services. & & & & & & & & & & & & 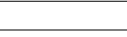 & & & \\
\hline 254 & 108 & FHE -1000 & Analysis of urine for & Am-243 & $1.3 \mathrm{E}-17$ & $1.0 E-03$ & 8.2 & 1.07 & 5.3 & None & 1 & $1.3 E-20$ & 1038 & ESE & $3.7 E-17$ & 1070 & NNE & $1.4 E-16$ & 1 \\
\hline & & & radionuclides & $\begin{array}{l}\text { Pu-242 } \\
\text { Pu-239 }\end{array}$ & $\begin{array}{l}\frac{1.6 \mathrm{E}-16}{2.6 \mathrm{E}-17} \\
\end{array}$ & $\begin{array}{l}\frac{1.0 E-03}{1.0 E-03} \\
\end{array}$ & & & & & & $\begin{array}{l}\frac{1.6 \mathrm{E}-19}{2.6 \mathrm{E}-20} \\
20\end{array}$ & & & & $\frac{1055}{849}$ & $\begin{array}{l}\text { SW } \\
\text { WWW }\end{array}$ & $\begin{array}{l}\frac{1.4 E-16}{1.4 E-16} \\
16\end{array}$ & \\
\hline & & & & $\mathrm{H}-3$ & 1.4E-14 & $1.0 E-03$ & & & & & & $\begin{array}{l}1.4 E-17 \\
.1-17\end{array}$ & & & & & & & \\
\hline & & & & $\frac{S-90}{Y-90}$ & $\begin{array}{l}3 . \mathrm{E}-14 \\
3.1 \mathrm{E}-14\end{array}$ & $\begin{array}{l}\frac{1.0 E-03}{1.0 E-03} \\
\end{array}$ & & & & & & $\begin{array}{l}3.1 E-17 \\
3.11-17\end{array}$ & & & & & & & \\
\hline 254 & 109 & FHE-1000 & Analysis of urine for & $\mathrm{Am}-243$ & $1.3 \mathrm{E}-17$ & $1.0 \mathrm{E}-03$ & 8.2 & 1.07 & 5.3 & None & 1 & $1.3 \mathrm{E}-20$ & 1038 & EEE & $1.5 E-18$ & 1070 & NNE & $5.9 \mathrm{E}-18$ & 1 \\
\hline & & 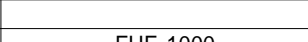 & & & & & & & & & 4 & & & & & & & & \\
\hline 204 & 110 & FHE-1000 & $\begin{array}{l}\text { Analysis of urnine for } \\
\text { radionuclides }\end{array}$ & $\frac{A m-241}{A m-243}$ & $\begin{array}{l}8.2 E-19 \\
2.3 E-17\end{array}$ & $\begin{array}{l}\frac{1.0 E-03}{1.0 E-03} \\
1.03\end{array}$ & 8.2 & 1.07 & 5.3 & None & 1 & 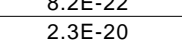 & 1038 & ESE & $1.3 E-11$ & 1070 & NNE & $5.0 \mathrm{E}-11$ & 1 \\
\hline & & & & $\mathrm{Cm}-244$ & $8.7 E-18$ & $1.0 \mathrm{E}-03$ & & & & & & $8.7 E-21$ & & & & & & & \\
\hline & & & & Np-237 & $\begin{array}{l}1.1 E-15 \\
80-17\end{array}$ & $\begin{array}{l}1.0 \mathrm{E}-03 \\
1.00-02\end{array}$ & & & & & & 1.1.1-18 & & & & & & & \\
\hline & & & & ct-5252 & $\begin{array}{l}8 \\
8.0 E-17 \\
8.0-17\end{array}$ & 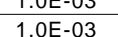 & & & & & & 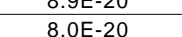 & & & & & & & \\
\hline & & & & U-233 & $2 . \pi$ & $1.0 \mathrm{EE}-03$ & & & & & & $2.7 E-22$ & & & & & & & \\
\hline & & & & $\mathrm{U}-234$ & $2.6 E-18$ & $1.0 \mathrm{E}-03$ & & & & & & $2.6 E-21$ & & & & & & & \\
\hline & & & & $-\frac{235}{4-32}$ & $\begin{array}{l}2.7-19 \\
3.3-19\end{array}$ & 1.0E-03 & & & & & & 2.76 20 & & & & & & & \\
\hline & & & & & 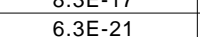 & $\begin{array}{l}0.0 \mathrm{E}-03 \\
1.0 \mathrm{E}-3\end{array}$ & & & & & & & & & & & & & \\
\hline & & & & Mixed gamma & $4.5 E-12$ & $1.0 \mathrm{E}-03$ & & & & & & $4.5 E-15$ & & & & & & & \\
\hline & & & & $\frac{C+2}{U-23}$ & $\frac{6.7 E-13}{6.4 E-13}$ & $\begin{array}{l}\frac{1.0 E-03}{1.0 E-03} \\
1.03\end{array}$ & & & & & & 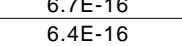 & & & & & & & \\
\hline & & & & Po-209 & $7.1 E-14$ & & & & & & & 7.1 & & & & & & & \\
\hline & & & & $\begin{array}{ll}\text { Put } 2424 \\
\text { Pu-239 }\end{array}$ & $\begin{array}{l}1.4 E-13 \\
2.2 E-14\end{array}$ & $\begin{array}{l}1.0 E-03 \\
1.0 E-03\end{array}$ & & & & & & $\begin{array}{l}1.4 E=10 \\
2.2 E-17\end{array}$ & & & & & & & \\
\hline & & & & P-32 & $7.0 E-12$ & $1.0 E-03$ & & & & & & $7.0 \mathrm{E}-15$ & & & & & & & \\
\hline & & & & $\begin{array}{l}5-35 \\
S-34 \\
\end{array}$ & $\begin{array}{l}\frac{3.25-12}{56-12} \\
56-12\end{array}$ & $\begin{array}{l}1.0 E-03 \\
10=03\end{array}$ & & & & & & $\begin{array}{l}3.2-1 \\
56-1\end{array}$ & & & & & & & \\
\hline
\end{tabular}


Attachment 1 - 2000 LLNL NESHAPs Annual Report Spreadsheet

\begin{tabular}{|c|c|c|c|c|c|c|c|c|c|c|c|c|c|c|c|c|c|c|c|}
\hline Building & Room/Area & Stack ID & Operation & Radionuclides & Annual Inventory & Physical & Stack & Stack & Stack & Control & Control Device & Estimated & $10 \mathrm{mrem} / \mathrm{y}$ Sitt & e-Wide Dose & e Requirement & $0.1 \mathrm{mrem}$ & Monitoring & Requirement & Source \\
\hline & & & & & $\begin{array}{l}\text { With Potential for } \\
\text { Release (Ci) }\end{array}$ & $\begin{array}{l}\text { state } \\
\text { Factor }\end{array}$ & Height $(m)$ & $\begin{array}{l}\text { Diameter } \\
\text { (i) }\end{array}$ & $\begin{array}{l}\text { Velocity } \\
(m / s) \\
(m)\end{array}$ & Device(s) & $\begin{array}{l}\text { Abatement } \\
\text { Factor } \\
\end{array}$ & $\begin{array}{l}\text { Annual Emissions } \\
\text { (i) }\end{array}$ & $\begin{array}{l}\text { Distance to } \\
\text { SwMEIm) }\end{array}$ & $\begin{array}{l}\text { Direction } \\
\text { to swMMI }\end{array}$ & $\frac{E D E}{\text { (merem) }}$ & $\begin{array}{ll}\text { Distance } \\
\text { to MEI (m) }\end{array}$ & $\begin{array}{l}\text { Direction } \\
\text { tom }\end{array}$ & $\begin{array}{l}\text { Unabated } \\
\text { EDF (mrem) }\end{array}$ & \\
\hline 254 & 110 & (continued) & & $\begin{array}{l}P-33 \\
1-125 \\
\end{array}$ & 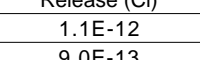 & $\begin{array}{l}1.00-03 \\
1.00-03\end{array}$ & & & & & & 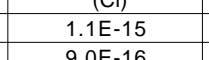 & & & & & & & \\
\hline & & & & $\begin{array}{l}1-125 \\
\text { sr-90 }\end{array}$ & $\begin{array}{l}\frac{9.0 E-13}{5.0 E-14} \\
5\end{array}$ & $\begin{array}{l}1.0 \mathrm{U}=\mathrm{C} 3 \\
.0 E-03 \\
\end{array}$ & & & & & & $\begin{array}{l}5.0 E-16 \\
5.0 E-17\end{array}$ & & & & & & & \\
\hline & & & & $\frac{Y-90}{\text { Np-237 }}$ & $\begin{array}{l}5.0 E-14 \\
1.1 E-10\end{array}$ & $\frac{1.0 E-03}{1.00-03}$ & & & & & & $\begin{array}{l}5.0 E-17 \\
1.1 E-13\end{array}$ & & & & & & & \\
\hline & & & & 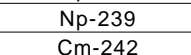 & $\begin{array}{ll}6.2 \mathrm{2E}-10 \\
91 \mathrm{~F}-13\end{array}$ & $\begin{array}{l}1.0 \mathrm{OE}-03 \\
1.00-03\end{array}$ & & & & & & $\begin{array}{ll}6.2 E-13 \\
9.11-16\end{array}$ & & & & & & & \\
\hline & & & & Th-230 & $9.4 E-12$ & $1.0 \mathrm{E}-03$ & & & & & & $9.4 E-15$ & & & & & & & \\
\hline & & & & $\frac{c f-252}{0-233}$ & $\begin{array}{l}8.4 \mathrm{E}-12 \\
2.2 \mathrm{E}-16\end{array}$ & $\begin{array}{l}1.00-03 \\
1.0 E-03 \\
\end{array}$ & & & & & & $\begin{array}{l}8.4 \mathrm{E}-15 \\
2.2 \mathrm{E}-19\end{array}$ & & & & & & & \\
\hline & & & & U-234 & $8.2 E-15$ & 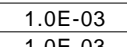 & & & & & & $8.2 E-18$ & & & & & & & \\
\hline & & & & $0-236$ & $\begin{array}{l}2.3 \mathrm{E}-16 \\
5.8 \mathrm{E}-14\end{array}$ & $\begin{array}{l}1.0 \mathrm{U}=0 \mathrm{~s} \\
1.0 \mathrm{-}-03 \\
\end{array}$ & & & & & & $\begin{array}{l}2.3 \mathrm{E}-19 \\
5.8 \mathrm{E}-17\end{array}$ & & & & & & & \\
\hline & & & & $u-238$ & $2.0 E-15$ & & & & & & & $2.0 \mathrm{E}-18$ & & & & & & & \\
\hline 254 & 113 & FHE-1000 & Analysis of urine for & Pu-242 & $1.6 E-16$ & $1.0 \mathrm{EE}-03$ & 8.2 & 1.07 & 5.3 & None & 1 & $1.6 \mathrm{E}-19$ & 1038 & ESE & $3.8 \mathrm{E}-17$ & 1070 & NNE & $1.4 E-16$ & 1 \\
\hline & & & & $\frac{P u-239}{H-3}$ & $\begin{array}{l}2.66-17 \\
1.4 E-14\end{array}$ & $\begin{array}{l}1.00-03 \\
1.0 E-03\end{array}$ & & & +4 & & & $\begin{array}{l}2.6 \mathrm{E}-20 \\
1.4 \mathrm{E}-17\end{array}$ & & & & $\frac{1555}{817}$ & $\frac{S W}{w}$ & $\begin{array}{l}1.4 E-16 \\
1.4 E-16\end{array}$ & \\
\hline & & & & $\frac{C-14}{\text { sr-90 }}$ & 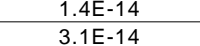 & $\begin{array}{l}1.0 \mathrm{E}=03 \\
100-03 \\
\end{array}$ & & & & & & $\begin{array}{l}1.4 \mathrm{E}-17 \\
3 . \mathrm{E}-17\end{array}$ & & & & 849 & & 1.4E-16 & \\
\hline & 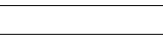 & & & $\mathrm{r}-90$ & $3.1 \mathrm{E}-14$ & $1.0 \mathrm{E}-03$ & & & & & & $3.1 \mathrm{E}-17$ & & & & & 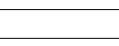 & & \\
\hline & & & & & & $1.0 E-03$ & & & & & & $1.3 E-20$ & & & & & & & \\
\hline Building 2 & 5 is operated by & azards Control and houses a rad & lation calibration and standards labor & atory. Many operati & ns involve the use 0 & sealed sour & es. & & & & & & & & & & & & \\
\hline 255 & 165 & FHE-4 & Analysis of urine for & $\begin{array}{l}1-125 \\
1-113\end{array}$ & $\begin{array}{l}2.3 \mathrm{E}-09 \\
7209\end{array}$ & $\begin{array}{l}1.0 \mathrm{E}-03 \\
0003\end{array}$ & 6.9 & 0.30 & 5.1 & None & 1 & $\frac{2.3 E-12}{2-12}$ & 1056 & E & $6.1 \mathrm{E}-12$ & 790 & w & $1.8 E-11$ & 1 \\
\hline & & & & Th-230 & $\begin{array}{l}5.72-149 \\
50-14\end{array}$ & $\begin{array}{l}1.00-03 \\
1.00-03\end{array}$ & & & & & & $\begin{array}{l}5.2 E-12 \\
5.7 E-17\end{array}$ & & & & & & & \\
\hline & & & & $\begin{array}{l}\text { Th-232 } \\
\text { U-233 }\end{array}$ & $\frac{1.0 E-16}{1.0 E-11}$ & $\begin{array}{l}1.0 \mathrm{E}-03 \\
10 \mathrm{E}-03\end{array}$ & & & & & & $\begin{array}{l}1.0 E-19 \\
100=14\end{array}$ & & & & & & & \\
\hline & & & & $\mathrm{U}-238$ & $1.3 \mathrm{E}-15$ & $\begin{array}{l}1.00=0 \\
1.0 E-03\end{array}$ & & & & & & $\begin{array}{ll}1.0-18 \\
1.3 E-18\end{array}$ & & & & & & & \\
\hline & & & & $\frac{\mathrm{Np}-237}{\mathrm{Cm}-24 \mathrm{~s}}$ & $5.7 E-14$ & $\begin{array}{l}1.0 \mathrm{OE}-03 \\
10 \mathrm{E}-03\end{array}$ & & & & & & $5.7-7-17$ & & & & & & & \\
\hline & & & & All-244 & $\begin{array}{l}3.8 \mathrm{C}-14 \\
3.8 \mathrm{E}-15\end{array}$ & 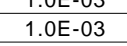 & & & & & & $\begin{array}{ll}3.0 \mathrm{E}-1 / \\
3.8 \mathrm{E}-18\end{array}$ & & & & & & & \\
\hline & & & & Am-243 & $\frac{1.9 E-14}{1.99-14}$ & $\begin{array}{l}1.0 \mathrm{OE}-03 \\
100-03\end{array}$ & & & & & & $\begin{array}{l}1.9 E-17 \\
100.17\end{array}$ & & - & & & & & \\
\hline & & & & Pu-242 & $1.9 E-15$ & $1.0 \mathrm{E}-03$ & & & & & & $1.9 \mathrm{E}-18$ & & & & & & & \\
\hline 255 & 180 & FHE-2 & Tritium gas monitor calibrations & $\mathrm{H}-3$ & $2.5 \mathrm{E}-02$ & $1.0 E+00$ & 8.1 & 0.31 & 5.2 & None & 1 & $2.5 \mathrm{E}-02$ & 1056 & $E$ & $9.9 \mathrm{E}-06$ & 790 & w & $3.9 E-05$ & 1 \\
\hline ilding 2 & 1 is part of the $\mathrm{E}$ & ergy and Environment Directorate & Tracer work, dissolution studies a & do flow studies are & onducted in this buil & Uing. & & & & & & & & & & & & & \\
\hline 281 & 1174 & FHE-13 & Tracer work & $\mathrm{Ni}-63$ & $1.0 \mathrm{E}-05$ & $1.0 \mathrm{E}-03$ & 6.7 & 0.30 & 6.1 & None & 1 & $1.0 E-08$ & 1332 & ESE & $2.4 E-11$ & 579 & NNE & $3.1 \mathrm{E}-10$ & 1 \\
\hline 281 & 1305 & Room air & Dissolution studies & U-238 & $4.3 E-09$ & $1.0 \mathrm{E}-03$ & NA & NA & NA & None & 1 & $4.3 E-12$ & 1332 & ESE & $1.0 \mathrm{E}-10$ & 753 & wNw & $1.8 \mathrm{E}-09$ & 1 \\
\hline 281 & 1307 & FHE-6 & Tracer work & Np-237 & $2.5 E-12$ & 1.0E-03 & 6.4 & 0.61 & 2.7 & None & 1 & $2.5 \mathrm{E}-15$ & 1332 & ESE & $4.0 E-08$ & 753 & WNW & $5.6 E-07$ & 1 \\
\hline & & & & $\frac{\mathrm{U}-238}{\mathrm{U}-235}$ & $\begin{array}{l}4.10 E-14 \\
5.28-16\end{array}$ & $\begin{array}{l}1.0 \mathrm{OE}-03 \\
1.0 \mathrm{E}-03\end{array}$ & & & & & & $\begin{array}{l}4.1 \mathrm{E}-17 \\
5.3 \mathrm{E}-19\end{array}$ & & & & & & & \\
\hline & & & & $\frac{U-234}{\text { Put239 }}$ & $\begin{array}{l}3.83 E-15 \\
3.3 E-07\end{array}$ & $\begin{array}{l}1.00-03 \\
1.0 E-03 \\
\end{array}$ & & & & & & $\begin{array}{l}3.8 \mathrm{E}-18 \\
3.3 \mathrm{E}-10\end{array}$ & & & & & & & - \\
\hline & & & & Pu-242 & $2.1 E-11$ & $1.0 \mathrm{E}-03$ & & & & & & $2.1 E-14$ & & & & & & & \\
\hline & & & & 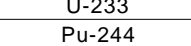 & $\begin{array}{l}2.33-5-8 \\
1.6 \mathrm{E}-09 \\
-109\end{array}$ & $\begin{array}{l}1.0 .0-503 \\
1.0 E-03\end{array}$ & & & & & & $\begin{array}{l}2.3 \mathrm{E}-11 \\
1.6 \mathrm{E}-12\end{array}$ & & & & & & & 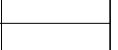 \\
\hline & & & & $\begin{array}{lll}N \text { Ni-63 } \\
\text { Nit.59 }\end{array}$ & $\frac{2.0 \mathrm{E}-04}{770.08}$ & $\frac{1.0 E-03}{1.00-03}$ & & & & & & $\frac{2.0 E-07}{770.0-11}$ & & & & & & & z \\
\hline & & & & $\begin{array}{ll}\text { TC-99 } \\
\text { SS-90 }\end{array}$ & $\begin{array}{l}1.0 \mathrm{E}-07 \\
10=0.55\end{array}$ & $\begin{array}{l}1.0 \mathrm{OE}-03 \\
100.03\end{array}$ & & & & & & $1.0 E-10$ & & & & & & & \\
\hline & & & & Ca-41 & $\frac{1.0 E-04}{1.0-0}$ & 1.0E-03 & & & & & & $\begin{array}{l}1.0 E-00 \\
1.0 E-07\end{array}$ & & & & & & & \\
\hline & & & & $\frac{B e-10}{P y-2390-233}$ & $\frac{1.0 E-05}{100-07}$ & $\begin{array}{l}1.0 \mathrm{E}-03 \\
100=03\end{array}$ & & & & & & $\begin{array}{l}1.0 E=-08 \\
10=10\end{array}$ & & & & & & & \\
\hline 281 & 1211 & EHE. 12 & Solution nrenarntion & & & & 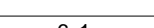 & 0 & 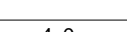 & Ser & 4 & & & & & & & & \\
\hline & (1014 & The-12 & - & Cl1-36 & $\begin{array}{l}1.05-05 \\
1.05-05\end{array}$ & $1.00=03$ & 0.1 & 0.41 & 4.0 & Nonte & & $\frac{1.9 E-0 /}{1.0 E-08}$ & 1002 & & 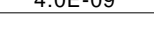 & 153 & WNow & 5.5E-08 & 1 \\
\hline & & & & $\mathrm{H}-3$ & $2.5 \mathrm{E}-05$ & 1.0E-03 & & & & & & $2.5 \mathrm{E}-08$ & & & & & & & \\
\hline 281 & 1323 & FHE-1 & Radioactivity migration studies & Na-22 & $8.0 \mathrm{E}-08$ & $1.0 E-03$ & 6.7 & 0.30 & 6.1 & None & 1 & $8.0 E-11$ & 1332 & ESE & $6.2 \mathrm{E}-09$ & 579 & NNE & $8.3 \mathrm{E}-08$ & 1 \\
\hline & & & & U-235 & 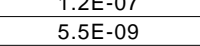 & $\begin{array}{l}1.00-0.33 \\
1.0 E-03\end{array}$ & & & & & & 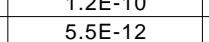 & & & & & & & \\
\hline & & & & U-234 & $1.3 \mathrm{E}-07$ & 1.0E-03 & & & & & & $1.3 E-10$ & & & & & & & \\
\hline Bulding ? 2 & 2 is administerec & by the Physics and Space Directr & orate. Residual contamination exists & nt the facility from $\mathrm{p}$. & st operations. $\mathrm{fl}$. & & & & & & & & & & & & & & \\
\hline 282 & 1000 & Room Air & Contamination & $\mathrm{H}-3$ & $4.0 E-06$ & $1.0 \mathrm{E}-03$ & $\mathrm{NA}$ & NA & $\mathrm{NA}$ & None & 1 & $4.0 \mathrm{E}-09$ & 1332 & ESE & $6.2 E-13$ & 753 & WNW & $1.1 \mathrm{E}-11$ & 1 \\
\hline
\end{tabular}


Attachment 1 - 2000 LLNL NESHAPs Annual Report Spreadsheet

\begin{tabular}{|c|c|c|c|c|c|c|c|c|c|c|c|c|c|c|c|c|c|c|c|}
\hline uiliding & Room/Area & Stack ID & Operation & Radionuclides & Annual Inventory & $\begin{array}{l}\text { Physical } \\
\text { Ssical }\end{array}$ & Stack & Stack & Stack & Control & Control Device & $\begin{array}{l}\text { Estimated } \\
\text { Estrexcion }\end{array}$ & $\frac{10 \mathrm{mrem} / \mathrm{S} \mathrm{Sit}}{\text { Ditsper th }}$ & $\begin{array}{ll}\text { ite-Wide Dose } \\
\text { Diroction }\end{array}$ & $\begin{array}{l}\text { se Requirement } \\
\text { REF }\end{array}$ & $\frac{0.1 \mathrm{mrem} / \mathrm{y}}{\text { Ditanc/ }}$ & Monitoring & $\begin{array}{l}\text { Requirement } \\
\text { Innabatod }\end{array}$ & $\begin{array}{l}\text { Source } \\
\text { Sategory }\end{array}$ \\
\hline & & & & & $\begin{array}{l}\text { with Potential for } \\
\text { Release (Ci) }\end{array}$ & $\begin{array}{l}\text { State } \\
\text { Factor }\end{array}$ & Height (m) & $\frac{\text { Diameter }}{(\mathrm{m})}$ & $\begin{array}{c}\text { Velocity } \\
\text { (m/s) }\end{array}$ & Device(s) & $\begin{array}{l}\text { Abatement } \\
\text { Factor } \\
\end{array}$ & & $\begin{array}{l}\text { Distance to } \\
\text { SWMEI (m) }\end{array}$ & \begin{tabular}{|l|} 
Direction \\
to SWMEI \\
\end{tabular} & $\begin{array}{l}\text { DEE } \\
\text { (mrem) }\end{array}$ & $\begin{array}{l}\text { Distance } \\
\text { to MEI (m) }\end{array}$ & $\begin{array}{l}\frac{D_{\text {ineretion }}}{\text { to MEI }} \\
\end{array}$ & $\begin{array}{l}\text { Unabated } \\
\text { EDE (mrem) }\end{array}$ & \\
\hline illiding 2: & 2 is administered & by the Environmental Programs I & rectorate. Residual contamination e & exists throughout the & facility from the pas & toperation o & a rotating targe & neutron source. & & & & & & & & & & & \\
\hline 292 & $\frac{1200,1202}{1204}$ & $\begin{array}{l}\text { Room Air } \\
\text { Poom Air }\end{array}$ & $\begin{array}{l}\text { Contamination } \\
\text { Contamination }\end{array}$ & $\frac{\mathrm{H}-3}{\mathrm{H}-3}$ & $\begin{array}{l}1.8 \mathrm{E}+00 \\
2.3 \mathrm{E}+01\end{array}$ & $\begin{array}{l}1.0 \mathrm{E}-03 \\
1.0 \mathrm{E}-03\end{array}$ & $\frac{N A}{N A}$ & $\frac{N A}{N A}$ & $\frac{N A}{N A}$ & $\begin{array}{l}\text { None } \\
\text { None }\end{array}$ & $\begin{array}{l}1 \\
1\end{array}$ & $\begin{array}{l}1.8 \mathrm{E}-03 \\
2.3-02\end{array}$ & 1380 & ESE & $3.9 E-06$ & 655 & w & $9.2 \mathrm{E}-05$ & 1 \\
\hline & $\begin{array}{l}1402,4402 \mathrm{~A} \\
102,40 \mathrm{~A}\end{array}$ & $\begin{array}{l}\text { Hoom Air } \\
\text { Room Air }\end{array}$ & $\begin{array}{l}\text { Conlaminuaton } \\
\text { Contamination }\end{array}$ & & $1.8 \mathrm{E}+00$ & $1.0 \mathrm{E}-03$ & $N A$ & & $\mathrm{NA}$ & $\begin{array}{l}\text { None } \\
\text { None }\end{array}$ & 1 & $1.8 \mathrm{E}-03$ & & & & & & & \\
\hline & $\begin{array}{c}1404,1406 \\
1407\end{array}$ & & & & & & & & & & & & & & & & & & \\
\hline Building 26: & 88 is part of the La & ser Fusion Program. Small amol & unts of tritium are used in this facility $i$ & in conjunction with f & usion target research & and develor & oment. & & & & & & & & & & & & 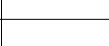 \\
\hline 298 & 160 & Room Air & D-T layering experiment & H.3 & $4.00-03$ & $1.0 E+00$ & $\mathrm{NA}$ & NA & NA & None & 1 & $4.0 \mathrm{E}-03$ & 1398 & $\Phi$ & 5.7E- -07 & 264 & NNE & $3.0 \mathrm{E}-05$ & 1 \\
\hline 298 & 189 & FHE-14 & Laser fusion target coating & U-238 & $1.3 \mathrm{E}-04$ & $1.0 \mathrm{E}-03$ & 6.4 & 0.63 & 15.1 & HEPA & 0.01 & $1.3 \mathrm{E}-09$ & 1398 & $\Phi$ & $1.9 \mathrm{E}-08$ & 344 & NE & $6.3 E-05$ & 1 \\
\hline 298 & Various & Room Air & $\begin{array}{l}\text { Laser fusion target research } \\
\text { and development }\end{array}$ & $\mathrm{H}-3$ & $1.0 \mathrm{E}-03$ & $1.0 E+00$ & NA & NA & NA & None & 1 & $1.0 \mathrm{E}-03$ & 1398 & $\Phi$ & $1.4 \mathrm{E}-07$ & 264 & NNE & $7.6 \mathrm{E}-06$ & 1 \\
\hline $\begin{array}{l}\text { Buildings } \\
\text { Uranium } \mathrm{p} \\
\mathrm{P}\end{array}$ & $\begin{array}{l}21,321 \mathrm{~A}, 321 \mathrm{~B}, \mathrm{a} \\
\text { eces may be work }\end{array}$ & $\begin{array}{l}\text { nd } 321 \mathrm{C} \text { are the Material Fabrical } \\
\text { ed on in a single location, or may }\end{array}$ & $\begin{array}{l}\text { tion Shops and are part of the Mechan } \\
\text { be moved from machine to machine. }\end{array}$ & $\begin{array}{l}\text { nical Engineering De } \\
\text { In addition, depletet }\end{array}$ & $\begin{array}{l}\text { partment. Operations } \\
\text { duranium parts occa }\end{array}$ & $\begin{array}{l}\text { sin this com } \\
\text { sionally und }\end{array}$ & $\begin{array}{l}\text { plex include milith } \\
\text { lergo heat treatme }\end{array}$ & $\begin{array}{l}\text { g, shaping and } m \\
\text { th }\end{array}$ & $\begin{array}{l}\text { achining of del } \\
\text { of depletetu duat }\end{array}$ & $\begin{array}{l}\text { pleted uranium. } \\
\text { nium that is handled } \mathrm{d}\end{array}$ & depends & & & & & & & & \\
\hline $\begin{array}{l}\text { on n rogran } \\
\text { "Stack ken }\end{array}$ & $\begin{array}{l}\text { Tmatic demands ar } \\
\text { iissions have been }\end{array}$ & $\begin{array}{l}\text { d varies from month to month. } \\
\text { combinind as permittited by the EF }\end{array}$ & 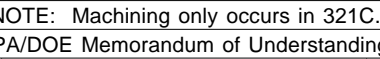 & & & & & & & & & & & & & & & & \\
\hline $321 \mathrm{~A}$ & $1001 \mathrm{~A}$ & FHE-24 & Machining and manufacturing & $\mathrm{U}-234$ & $7.5 E-04$ & $1.0 \mathrm{E}-06$ & 3.7 & 0.46 & 2.9 & HEPA & 0.01 & $7.5 E-12$ & 1032 & ENE & $1.10 \mathrm{E}-08$ & 326 & sw & $8.3 \mathrm{E}-06$ & 1 \\
\hline & & & & $\begin{array}{l}\mathrm{U}-235 \\
\mathrm{U}-238 \\
\mathrm{~m}\end{array}$ & $\begin{array}{l}\frac{1.0 E-04}{8.1 E-03} \\
\end{array}$ & $\begin{array}{l}1.00-06 \\
1.00-06\end{array}$ & & & & & & $\begin{array}{l}\frac{1.0 \mathrm{E}-12}{8.1 \mathrm{E}-11} \\
11\end{array}$ & & & & & & & \\
\hline $321 \mathrm{C}$ & $234 \mathrm{~B}$ & FHE-13 & Lapping of DU metal & U-238 & $1.6 \mathrm{E}-04$ & $1.0 \mathrm{E}-06$ & 10.7 & 0.49 & 2.5 & None & 1 & $1.6 \mathrm{E}-10$ & 1032 & ENE & $1.80 \mathrm{E}-08$ & 326 & sw & $4.2 E-08$ & 1 \\
\hline & & & & $\begin{array}{l}0-235 \\
U-234\end{array}$ & 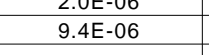 & 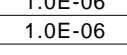 & & & & & & $\begin{array}{l}2.0 \mathrm{E}-12 \\
9.4 \mathrm{E}-12 \\
-x^{2}\end{array}$ & & & & & & & \\
\hline 3210 & Various" & FHE-9 & Machining and manufacturing & U-234 & $3.2 E+00$ & $1.0 E-06$ & 8.5 & 0.31 & 16.1 & HEPA & 0.01 & $3.2 E-08$ & 1032 & $\mathrm{DNE}$ & $3.46-08$ & 252 & SW & $6.2 \mathrm{E}-06$ & 1 \\
\hline & & $\begin{array}{l}\text { FHE- } 11 \\
\text { FHEE }\end{array}$ & & $\frac{U-235}{U-238}$ & $\begin{array}{l}4.0 E=-02 \\
3.0=0.01\end{array}$ & $\begin{array}{c}1.0 \mathrm{OE}-06 \\
100-06\end{array}$ & $\frac{12.5}{112}$ & 0.60 & $\frac{6.0}{13.4}$ & $\begin{array}{lll}\text { HEPA } \\
\text { HEA }\end{array}$ & 0.01 & $\begin{array}{l}4.0 E-10 \\
30-0.99\end{array}$ & & & & & & & \\
\hline & & FEV -1000 & & & & & 11.3 & 0.83 & 6.5 & HEPA & 0.01 & & & & & & & & \\
\hline Building 3z & 2 is operated by $t$ & ee Mechanical Engineering Depar & tment. & & & & & & & & & & & & & & & & - \\
\hline 322 & 109 & FHE-1 & Cleaning and plating & U-234 & $3.1 \mathrm{E}-07$ & $1.0 \mathrm{E}-06$ & 7.9 & 0.35 & 1.0 & None & 1 & 3.1E-13 & 930 & $\mathrm{QNE}$ & $5.0 E-10$ & 416 & SW & $1.8 \mathrm{E}-09$ & 1 \\
\hline & & & of depleted uranium & $\begin{array}{l}\text { U-235 } \\
-238 \\
\end{array}$ & $\begin{array}{l}4.3 \mathrm{E}-08 \\
3.3 \mathrm{E}-06\end{array}$ & $\frac{1.0 \mathrm{E}-06}{1.00-06}$ & & & & & & $\begin{array}{l}\frac{4.3 E-14}{3.3-12} \\
3-12\end{array}$ & & & & & & & \\
\hline Building $3 z$ & 27 is operated by t & e Mechanical Enginering Depar & tment. & $x_{0}$ & & & & & & & & 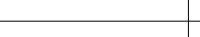 & & & & & & & \\
\hline 327 & 1275 & Boom Air & Non-destru & 4 & 1. & $10=06-5>3$ & $N A$ & No & $N A$ & None & 1 & 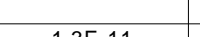 & 1018 & Do & $10500^{\circ}+3$ & $125,50+2$ & gin & 12507 & 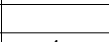 \\
\hline & & & material evaluation & U-235 & $1.9 \mathrm{E}-06$ & $1.0 \mathrm{EE}-06$ & & $\pi m$ & $n$ & Nowic & & $\frac{1.96-12}{1.95-12}$ & 年 & & 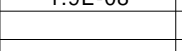 & & 政 & 1.2L & \\
\hline & 10 is & 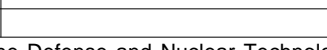 & 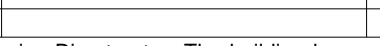 & the & 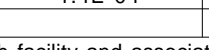 & thenter & & & & & & & & & & & & & \\
\hline 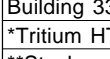 & $\begin{array}{l}\frac{3 \text { is operated by }}{\text { Tand HTo emissic }} \\
\text { The }\end{array}$ & $\begin{array}{l}\text { ene Deense and duclaer rechnold } \\
\text { ns from the two 30-m stacks are }\end{array}$ & $\begin{array}{l}\text { ogies Diriectorate. The bubiding gouses } \\
\text { continuously monitored in compliance }\end{array}$ & $\begin{array}{l}\text { st the ertitum researc } \\
\text { with NESHAPs reg }\end{array}$ & $\begin{array}{l}n \text { Facility and assocoiat } \\
\text { ulations. Monitoring }\end{array}$ & datalaboratarter & than the inventory & approach, are u & sed to determir & ee emissions. & & & & & & & & & \\
\hline 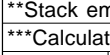 & $\begin{array}{l}\text { iissioins have been } \\
\text { ed dose of } 9.5 E-03\end{array}$ & $\begin{array}{l}\text { combinind as permitited by the EF } \\
\text { mrem includes modeling the HTT }\end{array}$ & 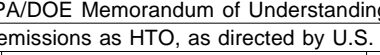 & EPA, Region IX. T & e dose from $H T$ and & HTO emissic & ins calculated app & ropriately using ti & e NEWTRIT $m$ & Iodel is 6.3e-03. See d & cussion on page & & & & & & & & \\
\hline 331 & $\mathrm{All}^{* *}$ & Stack 1 & Tritium research and development & H-3 & $\cdot$ & $1.0 E+00$ & 30.0 & 1.22 & 7.6 & None & 1 & $4.8 E+00$ & 957 & $\mathrm{EVE}$ & $9.5 \mathrm{E}-03$ & 957 & $B E$ & $9.5 \mathrm{E}-03$ & 3 \\
\hline & & Stack 2 & Decontamination of parts & $\mathrm{H}-3$ & & $1.0 E+00$ & 30.0 & 1.22 & 10.5 & None & 1 & $3.5 \mathrm{E}+01$ & & & & & & 6.3E-03 $\cdots$ & \\
\hline Building 3: & 32 is operated by $t$ & e Defense Sciences Program for & plutonium research. Exhausts from $\mathrm{g}$ & glove box operations & and the workplace & & & & & & & & & & & & & & \\
\hline $\begin{array}{l}\text { are triply } y \\
\text { abease }\end{array}$ & $\begin{array}{l}\text { Ititerd by high effic } \\
\text { ouildidng plutunonium }\end{array}$ & 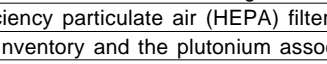 & 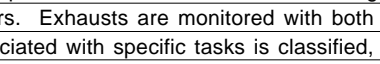 & $\begin{array}{l}\text { continousus fiter sa } \\
\text { the standard EESt }\end{array}$ & $\begin{array}{l}\text { mpling (PAMs) and } p \\
\text { (Aps aproach, nasec }\end{array}$ & 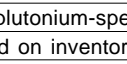 & 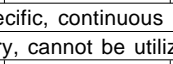 & $\begin{array}{l}\text { realtime monitor } \\
\text { eld without class }\end{array}$ & $\begin{array}{l}5 \text { (IAM)s. } \\
\text { tying this repor }\end{array}$ & The air monitoring & data for all emis & ion points & & & & & & & \\
\hline $\begin{array}{l}\text { show noc } \\
\text { "Because }\end{array}$ & $\begin{array}{l}\text { etectablel released } \\
\text { monitoring takes } \mathrm{p}\end{array}$ & $\begin{array}{l}\text { plutonoum activity, i.e.e at ob belo } \\
\text { lace anter HEPA filtration, an unat }\end{array}$ & 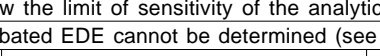 & $\begin{array}{l}\text { ical analysis. } \\
\text { ediscussion on page }\end{array}$ & 46.) & & & & & & & & & & & & & & \\
\hline 332 & Increment 1 & FHE-1000/2000 & Plutonium research & Transuranics & $*$ & $\mathrm{NA}$ & 8.8 & $0.8 \times 1.1$ & 17.3 & Double HEPA & 0.000001 & $0.0 \mathrm{E}+00$ & 912 & $\mathrm{QNE}$ & $0.0 E+00$ & $\because$ & .. & $\because$ & 3 \\
\hline 332 & Increment 1 - & FGBE-1000/2000 & Plutonium research & Transuranics & & NA & 11 & 0.3 & $6.97-3$ & Trinle HEPA & $000001-35)$ & 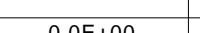 & 012 & 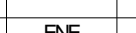 & 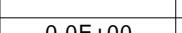 & .. & $*$ & & \\
\hline & Glove boxes & & & & & & & & & & & & & & & & & & \\
\hline 332 & Downdraft & FHE-4/5 & Plutonium research & Transuranics & 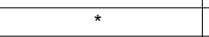 & $\mathrm{NA}$ & 11 & 0.2 & 14.2 & Double HEPA & 0.0001 & $0.0 E+00$ & 912 & $\mathrm{ENE}$ & $0.0 E+00$ & $m$ & $\cdots$ & $* *$ & 3 \\
\hline 332 & Loft & $\begin{array}{l}\text { FE-4 } \\
\text { FE-5 }\end{array}$ & $\begin{array}{l}\text { Plutonium research } \\
\text { Pultotium ressarch }\end{array}$ & 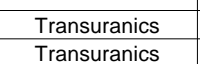 & & $\frac{N A}{N A}$ & $\frac{11}{11}$ & $\frac{0.6 \times 0.9}{0.60 .9}$ & $\begin{array}{l}\frac{4.6}{4.6} \\
4\end{array}$ & $\begin{array}{l}\text { HEPA } \\
\text { HEA }\end{array}$ & $\begin{array}{l}0.01 \\
0.01\end{array}$ & $\begin{array}{l}0.0 E+00 \\
0.0+00\end{array}$ & $\frac{912}{912}$ & $\frac{\mathrm{ENE}}{\mathrm{DE}}$ & $\begin{array}{l}0.0 E+00 \\
0.0 E+00\end{array}$ & * & $\because *$ & $\because *$ & $\begin{array}{l}3 \\
3 \\
\end{array}$ \\
\hline 332 & Increment 1 & FGBE-3000/4000 & Plutonium research & Transuranics & $\cdot$ & NA & 11 & 0.3 & 2 & Triple HEPA & 0.000001 & $0.0 E+00$ & 912 & $\mathrm{ENE}$ & $0.0 巨+00$ & .. & $* *$ & 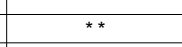 & 3 \\
\hline
\end{tabular}


Attachment 1 - 2000 LLNL NESHAPs Annual Report Spreadsheet

\begin{tabular}{|c|c|c|c|c|c|c|c|c|c|c|c|c|c|c|c|c|c|c|c|}
\hline Building & Room/Area & Stack ID & Operation & Radionuclides & Annual Inventory & $\begin{array}{l}\text { Physical } \\
\text { hyical }\end{array}$ & Stack & Stack & Stack & Control & Control Device & Estimated & $\frac{10 \mathrm{mrem} / \mathrm{s}}{0 \mathrm{~s}}$ & Site-Wide Dos & se Requirement & $0.1 \mathrm{mrem} / \mathrm{s}$ & Monitoring & Requirement & Source \\
\hline & & & & & $\begin{array}{l}\text { with Petontial for } \\
\text { Release (ii) }\end{array}$ & $\begin{array}{l}\text { State } \\
\text { Factor }\end{array}$ & Height $(m)$ & $\begin{array}{c}\frac{D}{D i a m t e r} \\
(\mathrm{~m})\end{array}$ & $\frac{\text { Velocity }}{(\text { (m) }}$ & Device(s) & $\begin{array}{l}\text { Abatament } \\
\text { Factor } \\
\end{array}$ & $\begin{array}{l}\text { Annual } \text { (isisions } \\
(\mathrm{Ci})\end{array}$ & $\begin{array}{l}\text { Distance e } \\
\text { SWMEI(m) }\end{array}$ & $\begin{array}{l}\text { Diriection } \\
\text { to sWMEI }\end{array}$ & $\frac{\mathrm{DDE}}{\text { (mrem) }}$ & $\begin{array}{l}\text { Distance } \\
\text { to MEI (m) } \\
\end{array}$ & $\begin{array}{l}\text { Diection } \\
\text { to MEI } \\
\end{array}$ & $\begin{array}{l}\text { Unabatad } \\
\text { EDE (merem) }\end{array}$ & \\
\hline 332 & $\begin{array}{l}\text { Increment } 3 \\
\text { Pone and } \\
\end{array}$ & $\begin{array}{l}\text { FFE-1000/2000 } \\
\text { FGEF-7002/8000 }\end{array}$ & Plutonium research & Transuranics & * & NA & 10.1 & 0.9 & 12.2 & $\begin{array}{l}\text { Room-Double HEPA } \\
\text { Silove Rox-Tring }\end{array}$ & 0.000001 & $0.0 \mathrm{E}+00$ & 912 & ENE & $0.0 E+00$ & $*$ & * & ** & 3 \\
\hline & Glove boxes & & & & & & & & & & & & & & & & & & \\
\hline Building 3 & 11 is a Lasers Dir & ctorate facility. & & & & & & & & & & & & & & & & & \\
\hline 341 & 1107 & Room Air & Blower decontamination & U-238 & $9.6 \mathrm{E}-10$ & $1.00 E-03$ & $\mathrm{NA}$ & NA & NA & None & 1 & $9.6 \mathrm{E}-13$ & 872 & $\mathrm{E}$ & 1.1E-10 & $\frac{770}{501}$ & $\begin{array}{c}\text { sw } \\
\text { cwing }\end{array}$ & $2.900-10$ & 1 \\
\hline & & & & $\begin{array}{l}0.235 \\
U-234 \\
\end{array}$ & $\frac{1.2 E-11}{8.9 E-11}$ & 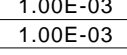 & & & & & & $\begin{array}{l}\frac{1.2 E-14}{8.9 E-14} \\
8\end{array}$ & & & & & & & \\
\hline The rese: & ch complex for th & Biology and Biotechnology Rese & earch Directorate includes Buildings & $61,362,363,364$ & 365,366 and $377 . \quad B$ & sulding 365 & ontains & & & & & & & & & & & & \\
\hline $\begin{array}{ll}\text { satall am } \\
\text { at least ty }\end{array}$ & 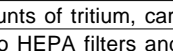 & 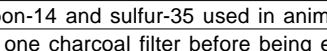 & 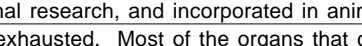 & $\begin{array}{l}\text { al carcasses stored } \\
\text { nntained radionuclid }\end{array}$ & $\begin{array}{l}\text { frozen pending dispo: } \\
\text { fs have been remove }\end{array}$ & $\begin{array}{l}\text { soll. The bui } \\
\text { d trom the a }\end{array}$ & $\begin{array}{l}\text { ding air is ifterec } \\
\text { dimals tor examin }\end{array}$ & Ithrough & & & & & & & & & & & \\
\hline The radio & ulide sources in & Builiding 361 include tritium, carb & on-14, phosphorous-32, phosphorou & -33 , and sulfur -35 , & nostly incorporated a & is consitituen & atoms (tracers) & in organic com & jounds. & & & & & & & & & & \\
\hline 361 & 1020 & Room Air & DNA hybridization & P-32 & 1.3E-03 & $1.0 \mathrm{0}-03$ & $\mathrm{NA}$ & $\mathrm{NA}$ & NA & None & 1 & 1.3E-06 & 918 & EEE & 2.1E-08 & 976 & w & 1.1E-07 & 1 \\
\hline 361 & 1238 & Room Air & P.32 Labeling & $P-32$ & $8.0 E-05$ & $1.0 \mathrm{E}-03$ & NA & $\mathrm{NA}$ & $\mathrm{NA}$ & None & 1 & $8.0 \mathrm{E}-08$ & 918 & ESE & $1.3 \mathrm{E}-09$ & 976 & w & $7.0 \mathrm{E}-09$ & 1 \\
\hline 361 & 1445 & Room Air & Radiolabeling of DNA substrates & $\begin{array}{l}P-32 \\
\text { S-35 }\end{array}$ & $\begin{array}{l}2.2 E-04 \\
4.11-04\end{array}$ & $\begin{array}{l}1.0 \mathrm{OE}-03 \\
1.0 \mathrm{O}-03\end{array}$ & $\mathrm{NA}$ & NA & NA & None & 1 & $\begin{array}{l}2.2 E-07 \\
41 E-07\end{array}$ & 918 & EEE & $6.2 \mathrm{2E}-09$ & 976 & w & 3.4E- -08 & 1 \\
\hline 361 & 1446 & FHE-15 & Radiolabeling of DNA substrates & P-32 & $5.5 \mathrm{E}-04$ & $1.0 \mathrm{E}-03$ & 6.2 & 0.42 & 1.7 & None & 1 & $5.5 \mathrm{E}-07$ & 918 & ESE & $8.7 E-09$ & 976 & $\mathrm{w}$ & $4.7 \mathrm{7E}-08$ & 1 \\
\hline 361 & 1542 & FHE-12 & Hybridization and enzyme assay & $P-32$ & $2.0 E-07$ & 1.0E-03 & 7.0 & 0.41 & 4.4 & None & 1 & $2.0 E-10$ & 918 & ESE & $2.9 E-12$ & 976 & w & $1.5 E-11$ & 1 \\
\hline 361 & 1546 & FHE-10 & DNA protein interaction studies & $P-32$ & $3.2 E-04$ & 1.0E-03 & 1.7 & 0.41 & 0.5 & None & 1 & 3.2E-07 & 918 & ESE & $4.9 E-09$ & 976 & w & $2.5 \mathrm{E}-08$ & 1 \\
\hline 361 & 1664 & Room Air & DNA hybridization & $P-32$ & $6.4 E-04$ & $1.0 \mathrm{E}-03$ & $\mathrm{NA}$ & NA & NA & None & 1 & $6.4 \mathrm{E}-07$ & 918 & ESE & $1.0 \mathrm{E}-08$ & 976 & w & $5.6 E-08$ & 1 \\
\hline 361 & 1742 & FHE-8 & DNA hybridization & P-32 & $2.2 \mathrm{E}-04$ & $1.0 \mathrm{E}-03$ & 7.0 & 0.41 & 4.4 & None & 1 & $2.2 E-07$ & 918 & ESE & $3.3 \mathrm{E}-09$ & 976 & w & $1.7 \mathrm{EE}-08$ & 1 \\
\hline 361 & 1846 & Room Air & Human genome research & $P-32$ & $2.6 \mathrm{E}-04$ & $1.0 \mathrm{E}-03$ & $\mathrm{NA}$ & $\mathrm{NA}$ & $\mathrm{NA}$ & None & 1 & $2.6 E-07$ & 918 & EEE & $4.2 E-09$ & 976 & w & $2.3 \mathrm{E}-08$ & 1 \\
\hline Building: & & & & & & & & & & & & & & & & & & & \\
\hline 362 & 105 & FHE-1000 & Compound purfifaction by HPLC & $\begin{array}{l}H-13 \\
C-14 \\
-1\end{array}$ & $\begin{array}{l}1.00-04 \\
1.0 E-04 \\
\end{array}$ & $\begin{array}{l}1.0 .0-03 \\
1.0 E-03 \\
\end{array}$ & 6.8 & 0.65 & 2.7 & None & 1 & $\begin{array}{l}1.00-0.07 \\
1.0 E-07 \\
\end{array}$ & 992 & ESE & $1.4 \mathrm{E}-09$ & 893 & w & $9.4 E-09$ & 1 \\
\hline 362 & 106 & FHE-1000 & $\begin{array}{l}\text { Characterization of } \\
\text { metablyic nthwavc }\end{array}$ & $\frac{C-14}{H-3}$ & $\begin{array}{l}1.0 E-08 \\
505=04\end{array}$ & $\begin{array}{l}1.0 \mathrm{OE}-03 \\
1.0 .03\end{array}$ & 6.8 & 0.65 & 2.7 & None & 1 & 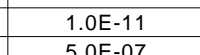 & 992 & ESE & $6.7 E-09$ & 893 & w & $4.6 E-08$ & 1 \\
\hline lding: & & & & & & & & & & & & & & & & & & & \\
\hline 363 & 1009 & FHE-2000 & Human urine sample project & $\frac{H-3}{C-14}$ & $\begin{array}{l}\frac{1.00-09}{1.00-09} \\
10.09\end{array}$ & $\begin{array}{l}1.0 \mathrm{OE}-03 \\
1.0-03\end{array}$ & 1.7 & 0.41 & 0.4 & HEPA & 0.01 & $\begin{array}{l}1.0 E-14 \\
10 E-14\end{array}$ & 1000 & ESE & $1.5 E-16$ & 888 & w & $1.2 E-13$ & 1 \\
\hline 363 & 1010 & Room Air & HPLC analysis & $\mathrm{H}-3$ & $10 E-09$ & $10 \mathrm{E}-03$ & NA & NA & $N A$ & None & 1 & & 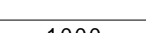 & Cor & $10 \overline{11}$ & 200 & We & & \\
\hline & & 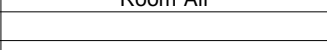 & 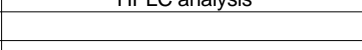 & C-14 & $\begin{array}{l}1.05-09 \\
1.05-109\end{array}$ & $1.0 E-03$ & & $\mathrm{NA}$ & NA & None & 1 & $\begin{array}{l}1.0 E-12 \\
1.0 E-12\end{array}$ & 1000 & $E x=$ & $1.6 E^{-14}$ & 888 & $w$ & 1.3E-13 & 1 \\
\hline Building: & & & & & & & & & & & & & & & & & & & \\
\hline 364 & 1509 & FHE-02P & AMS sample preparation & $\begin{array}{l}\mathrm{H}-3 \\
\mathrm{C}-14\end{array}$ & $\begin{array}{l}5.5 E-14 \\
5.5 E-07\end{array}$ & $\begin{array}{l}\frac{1.0 E+00}{1.0 E+00} \\
1.0\end{array}$ & 5.5 & 0.52 & 2.9 & None & 1 & $\begin{array}{l}5.5 E-14 \\
5.5 E-07\end{array}$ & 987 & ESE & $8.66-09$ & 912 & $\mathrm{w}$ & $6.8 \mathrm{E}-08$ & 1 \\
\hline 364 & $1509 \mathrm{~A}$ & Room Air & AMS sample preparation & $\begin{array}{l}\mathrm{H}-3 \\
-14 \\
\end{array}$ & $\begin{array}{l}5.5 E-14 \\
5.5-07\end{array}$ & $\begin{array}{l}1.0 E+00 \\
1.0+000\end{array}$ & $\mathrm{NA}$ & NA & $\mathrm{NA}$ & None & 1 & $\begin{array}{l}5.5 E-14 \\
555-07\end{array}$ & 987 & ESE & $7.96-09$ & 912 & w & $5.6 \mathrm{E}-08$ & 1 \\
\hline 364 & 1519 & Room Air & DNA and nrtetin extraction & & & & $N N^{2}$ & No & 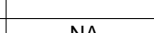 & $N$ & 5 & 50500 & (ang & & 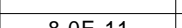 & 010 & Ww & & \\
\hline & Nolu & Froom Alr & DNA and proteln exfracion & $\begin{array}{c}\mathrm{H}-14 \\
\mathrm{H}-3 \\
\end{array}$ & $\begin{array}{l}5.0 E=-06 \\
5.06-06\end{array}$ & 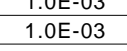 & NA & $\mathrm{NA}$ & NA & None & 1 & 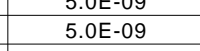 & 981 & ESE & $8.0 E-11$ & 912 & w & 6.3E-TI & 1 \\
\hline Building: & & & & & & & & & & & & & & & & & & & \\
\hline 365 & 104 & FHE-1000 & Equipment decontamination & $\frac{C-14}{\mathrm{H}-3}$ & $\begin{array}{l}1.0 \mathrm{E}-09 \\
1.0 \mathrm{E}-09\end{array}$ & $\begin{array}{l}1.0 \mathrm{DE}-03 \\
1.0 E-03\end{array}$ & 6.1 & 0.58 & 7.2 & HEPA & 0.01 & $\begin{array}{l}\frac{1.0 E-14}{1.0 E-14} \\
1.0\end{array}$ & 991 & ESE & $1.2 E-16$ & 902 & w & $6.1 \mathrm{E}-14$ & 1 \\
\hline 365 & 109 & FHE-5 & Animal housing & C-14 & $1.3 \mathrm{E}-05$ & $1.0 \mathrm{E}-03$ & 1.7 & 0.41 & 0.6 & Double HEPA & 0.0001 & $1.3 \mathrm{E}-12$ & 991 & ESE & $2.0 \mathrm{E}-14$ & 902 & w & $1.6 \mathrm{E}-09$ & 1 \\
\hline & & & & $\mathrm{H}-3$ & $5.0 \mathrm{E}-08$ & $1.0 \mathrm{E}-03$ & & & & & & $5.0 E-15$ & & & & & & & \\
\hline Building : & 111 & Room Air & Labeling & $P-32$ & $20 E=03$ & $10=03$ & $N A$ & $N A$ & $N A$ & None & 1 & 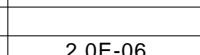 & & FSE & $32 E-08$ & 998 - & W & 17 E-07 & 1 \\
\hline 366 & & & Labeing & $p=32$ & 20000 & $1.0 E=03$ & n & 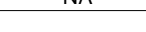 & nn & None & 1 & $2.0 E-06$ & 923 & 然 & $3.2 E=08$ & 998 & $w$ & $1.1 E=0$ r & 1 \\
\hline Building 3 & 8 is part of the $\mathrm{E}$ & ergy and Environment Directoratet & 2. Small quantities of radioactive tra & ers are handled in 1 & is building. & & & & & & & & & & & & & & \\
\hline 378 & 105 & FHE-1,11 & Tracer work & Am-243 & $9.2 E-12$ & 1.0E-03 & 8.5 & 0.30 & 5.8 & None & 1 & $9.2 E-15$ & 875 & ESE & $4.2 E-12$ & 1041 & w & $1.9 E-11$ & 1 \\
\hline & & & & $\frac{\text { Pu-239 }}{\text { Pu-242 }}$ & $\begin{array}{l}1.5-5-14 \\
1.5 E-12\end{array}$ & $\begin{array}{l}1.0 E-03 \\
1.0 E-03\end{array}$ & & & & & & $\begin{array}{l}1.55-17 \\
1.5 E-15\end{array}$ & & & & & & & \\
\hline & & & & 233 & $6 \mathrm{E}-1$ & $1.0 \mathrm{E}-03$ & & & & & & 6 EE-14 & & & & & & & \\
\hline
\end{tabular}


Attachment 1 - 2000 LLNL NESHAPs Annual Report Spreadsheet

\begin{tabular}{|c|c|c|c|c|c|c|c|c|c|c|c|c|c|c|c|c|c|c|c|}
\hline Building & Room/Area & Stack ID & Operation & Radionuclides & 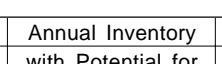 & \begin{tabular}{|l|l|l} 
Physical \\
ytat
\end{tabular} & $\begin{array}{c}\text { Stack } \\
\text { Heint } \\
\text { Hent }\end{array}$ & $\begin{array}{ll}\text { Stack } \\
\text { Dianotor }\end{array}$ & $\begin{array}{l}\text { Stack } \\
\text { Velocilivg }\end{array}$ & $\begin{array}{lll}\text { Control } \\
\text { Rovicaly }\end{array}$ & \begin{tabular}{|l|} 
Control Device \\
Antolmont
\end{tabular} & 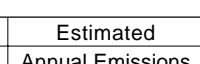 & $\frac{10 \mathrm{mrem} / \mathrm{S}}{0 . \mathrm{sin}}$ & $\begin{array}{l}\text { Siti-Wide Dos } \\
\text { ie Dirction }\end{array}$ & se Requirement & $\frac{0.1 \mathrm{mrem}}{\text { D. }}$ & \begin{tabular}{|l|l} 
Monititong \\
Dinction
\end{tabular} & Reauirement & $\begin{array}{l}\text { Source } \\
\text { stoperent }\end{array}$ \\
\hline & & & & & $\begin{array}{l}\text { with Potential or } \\
\text { Release (Ci) }\end{array}$ & \begin{tabular}{|l|l|} 
State \\
Factor \\
\end{tabular} & Height (m) & $\frac{D_{\text {Diameter }}}{(\mathrm{m})}$ & $\frac{v^{\frac{V}{2}}}{(\mathrm{~m} / \mathrm{s})}$ & Device(s) & \begin{tabular}{|c|} 
Abatement \\
Factor \\
\end{tabular} & \begin{tabular}{|l} 
Annual Emissions \\
(Ci)
\end{tabular} & $\begin{array}{l}\text { Distance to } \\
\text { SWMEI (m) }\end{array}$ & $\begin{array}{l}\text { Direction } \\
\text { to SWMEI }\end{array}$ & $\begin{array}{l}\text { DE } \\
\text { (mrem) }\end{array}$ & $\begin{array}{l}\text { Distance } \\
\text { to MEI (m) }\end{array}$ & $\begin{array}{l}\text { Direction } \\
\text { to MEI }\end{array}$ & $\begin{array}{l}\text { Unabated } \\
\text { EDE (mrem) }\end{array}$ & ategory \\
\hline 378 & 120 & FHE- $-1,2,3,4,5,8,9,10$ & Tracer work & Am-241 & $1.2 \mathrm{E}-08$ & $1.0 E-03$ & 8.5 & 0.30 & 5.9 & None & 1 & 1.2E-11 & 875 & ESE & $2.6 E-09$ & 1041 & w & $1.2 \mathrm{E}-08$ & \\
\hline & & & & $\begin{array}{l}\text { Am-243 } \\
\text { Cd-109 }\end{array}$ & $\begin{array}{l}7.7 E-11 \\
7.7 E-09\end{array}$ & $\begin{array}{l}1.0 \mathrm{E}-03 \\
1.0 \mathrm{E}-03 \\
\end{array}$ & & & & & & $\begin{array}{l}7.7 \mathrm{E}-14 \\
7.7 \mathrm{E}-12 \\
\end{array}$ & & & & & & & \\
\hline & & & & $\begin{array}{ll}0.57 \\
0.50 \\
0.50\end{array}$ & $\begin{array}{l}3.1 E-10 \\
.250\end{array}$ & $\begin{array}{l}1.0 \mathrm{E}-03 \\
1.0 \mathrm{C}-03\end{array}$ & & & & & & $\begin{array}{l}3.1 E-13 \\
325.11\end{array}$ & & & & & & & \\
\hline & & & & Cs-134 & $\begin{array}{ll}1.56-0.07 \\
1.5-07\end{array}$ & $\begin{array}{l}x_{1.0 E-03} \\
1.0 \mathrm{E}-03 \\
\end{array}$ & & & & & & $\begin{array}{l}1.5 E-10 \\
1.5 E-10\end{array}$ & & & & & & & \\
\hline & & & & $\begin{array}{l}\text { Cs-137 } \\
\text { Np-237 }\end{array}$ & $\begin{array}{l}\frac{1.5 E-08}{3.1 E-13} \\
3.14\end{array}$ & $\begin{array}{l}\frac{1.0 E-03}{1.0 E-03} \\
1.02\end{array}$ & & & & & & $\begin{array}{l}\frac{1.5 E-11}{3.1 E-16} \\
3.16\end{array}$ & & & & & & & \\
\hline & & & & Pu-240 & $\begin{array}{l}1.3 E-11 \\
1.2 E-11 \\
11\end{array}$ & $\begin{array}{l}1.0 E-03 \\
1.0 E-03 \\
\end{array}$ & & & & & & $\begin{array}{l}\frac{1.5 \mathrm{E}-14}{1.2 \mathrm{E}-14} \\
14\end{array}$ & & & & & & & \\
\hline & 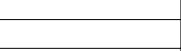 & & & $\begin{array}{l}\text { Pu-242 } \\
\text { Pu-2244 }\end{array}$ & $\frac{1.5 E-12}{7.7 E-11}$ & $\begin{array}{l}\frac{1.0 \mathrm{E}-03}{1.0 \mathrm{E}-03} \\
\end{array}$ & & & & & & 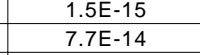 & & & & & & & \\
\hline & & & & $\begin{array}{ll}\mathrm{Sr}-85 \\
14-238\end{array}$ & $\begin{array}{l}1.4 \mathrm{~L}-08 \\
1.55-13\end{array}$ & $\begin{array}{l}1.0 \mathrm{E}-03 \\
1.0 \mathrm{E}-03\end{array}$ & & & & & & $\begin{array}{l}1.4 \mathrm{E}-11 \\
5-16\end{array}$ & & & & & & & \\
\hline & $\bar{C}$ & & & $\begin{array}{l}0-235 \\
U-235 \\
\end{array}$ & (1.0E-13 & $\begin{array}{l}1.0=-03 \\
1.0 E-03 \\
\end{array}$ & -5 & & -5 & 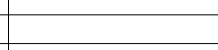 & & 6.8E-18 & & & & & & & \\
\hline & & & & $\begin{array}{l}-2-24 \\
U-238 \\
\end{array}$ & 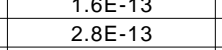 & $\begin{array}{l}1.0 E-03 \\
1.0 E-03\end{array}$ & & & & & & $\begin{array}{l}\frac{1.6 \mathrm{E}-16}{2.8 \mathrm{E}-16} \\
2 .\end{array}$ & & & & & & & \\
\hline & & & & $\frac{\mathrm{U}-235}{\mathrm{U}-234}$ & $\begin{array}{l}3.6-6-15 \\
2.6 E-14\end{array}$ & 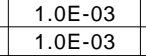 & & & & & & $\begin{array}{l}3.6 \mathrm{E}-18 \\
2.6 \mathrm{E}-17\end{array}$ & & & & & & & \\
\hline Building 4 & 1 was part of the 1 & Uranium Atomic Vapor Laser Is & tope Separation (U-AVLIS) program, o & operated by The Unii & ted States Enrichment & it Corporation ( & (USEC). In June 1 & 1999, USEC sus & spended further & development of the U & -AVLIS technology. & & & & & & & & \\
\hline Stack sa & pling is continuous & 5. The facility operates with tw & in-series high efficiency particulate (1) & HEPA) filter banks to & control emissions. & & & & & & & & & & & & & & \\
\hline 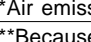 & $\begin{array}{l}\text { Ons a are continuous } \\
\text { monitoring takes } \mathrm{p}\end{array}$ & ly sampled at the post-HEPA-fil & er atmospheric discharge points, altho & Dugh emissions are I & $\begin{array}{ll}\text { ow enough } \\
\text { le } 46 .\end{array}$ & onitoring is & not required per $t$ & the NESHAPS $4 \mathrm{C}$ & to CFR 61 regule & lations. & & & & & & & & & \\
\hline 491 & All & 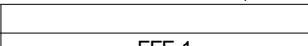 & 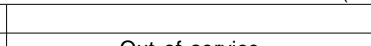 & & 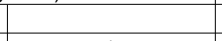 & & & & & & & & 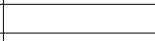 & 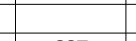 & 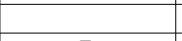 & 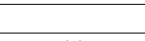 & 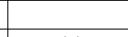 & -5 & \\
\hline & All & FFE-1 & Out of service & $\begin{array}{l}\text { Gross apha } \\
\text { Gross beta }\end{array}$ & ${ }^{*}$ & NA & 9.1 & 0.9 & 12.1 & Double HEPA & 0.0001 & $\begin{array}{l}0.0 \mathrm{E}+00 \\
0.0 \mathrm{E}+00\end{array}$ & 1000 & SSE & $0.0 E+00$ & $\because \cdot$ & 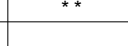 & $\cdots$ & 3 \\
\hline Building 5 - & 3 is operated by th & e Hazardous Waste Manageme & th Division. The Stabilization Unit is a & mechanized mixing & device used to make & homogeneous & Is mixtures of was & ste. Solidification & $n$ agents are a & Ided during mixing to $t$ & ransfer sludges to & 0 os solds. & & & & & & & \\
\hline The Micre & Itration Unit filters & out waste radioactive particles. & In the Laboratory, small quantities of & waste materials are & sampled, treated, and & d stored. No & 0 releases are ass & ssumed to occurt & from waste store & rage because the was & tes are fully contail & ained. & & & & & & & \\
\hline 513 & Stabilization & Room Air & Treatment of hazarardous, mixed & $1-125$ & $2.6 \mathrm{E}-06$ & $1.0 \mathrm{E}-03$ & NA & $\mathrm{NA}$ & NA & None & 1 & $2.6 \mathrm{E}-09$ & 588 & NE & $4.3 \mathrm{E}-06$ & 128 & sw & $1.9 \mathrm{E}-05$ & 1 \\
\hline & & & or radioactive waste & $\frac{1-131}{C_{s-137}}$ & $\begin{array}{l}9.4 E-08 \\
835-507\end{array}$ & $\begin{array}{ll}1.0 E-03 \\
1.0 E-03\end{array}$ & & & & & & $\begin{array}{l}9.4 E-11 \\
83=-10\end{array}$ & & & & & & & \\
\hline & & & & $0-14$ & $8.6-04$ & $\begin{array}{l}1.0 \mathrm{E}-03 \\
\end{array}$ & & & & & & $8.6 \mathrm{E}-07$ & & & & & & & \\
\hline & & & & $\frac{C s-144}{B-133}$ & 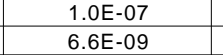 & $\begin{array}{l}1.0 E-03 \\
1.0 E-03\end{array}$ & & & & & & $\begin{array}{l}\frac{1.0 E-10}{6.6 E-12} \\
6.12\end{array}$ & & & & & & & \\
\hline & & & & $\begin{array}{c}\text { P. } 32 \\
\text { Pu-238 }\end{array}$ & $\begin{array}{l}1.1 E-05 \\
610-5=9\end{array}$ & $\begin{array}{ll}1.0 \mathrm{E}-03 \\
1.0 \mathrm{E}-03\end{array}$ & & & & & & 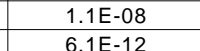 & & & & & & & \\
\hline & & & & Pu-239 & $4.8 E-07$ & $1.0 \mathrm{E}-03$ & & & & & & $4.8 E-10$ & & & & & & & \\
\hline & & & & $\frac{P_{u-240}}{\text { Am-241 }}$ & $\begin{array}{l}7.1 \mathrm{E}-\mathrm{-}-8 \\
1.4 \mathrm{E}-07\end{array}$ & $\begin{array}{l}\frac{1.0 \mathrm{E}-03}{1.0 \mathrm{E}-03} \\
\end{array}$ & & & & & & $\begin{array}{l}7.1 \mathrm{E}-11 \\
1.4 \mathrm{E}-10\end{array}$ & & & & & & & \\
\hline & & & & Pu-241 & $4.5 \mathrm{E}-06$ & $\begin{array}{ll}1.0 E-03 \\
.0-02\end{array}$ & & & & & & $\begin{array}{l}4.5 \mathrm{E}-09 \\
6-1 .\end{array}$ & & & & & & & \\
\hline & & & & $\begin{array}{l}\text { Th-232 } \\
\text { Pu-242 }\end{array}$ & $\begin{array}{l}1.0 E=-08 \\
2.4 E-06\end{array}$ & $\begin{array}{l}\frac{1.0 E-03}{1.0 E-03} \\
\end{array}$ & & & & & & $\begin{array}{l}1.6 \mathrm{E}-11 \\
2.4 \mathrm{E}-09\end{array}$ & & & & & & & \\
\hline 513 & $1000 \mathrm{~A}$ & FHE-4 & Process optimization and & $1-125$ & $7.8 E-07$ & $1.0 E-03$ & 10.5 & 0.30 & 5.5 & HEPA & 0.01 & $7.8 E-12$ & 588 & $N E$ & $8.7 \mathrm{E}-09$ & 128 & SW & $1.3 \mathrm{E}-08$ & 1 \\
\hline & & & treatibility studies & $\frac{1-131}{C s-137}$ & $\begin{array}{l}2.8 E-08 \\
2.5 E-07\end{array}$ & $\begin{array}{l}\frac{1.0 \mathrm{E}-03}{1.0 \mathrm{E}-03} \\
-1\end{array}$ & & & & & & $\begin{array}{l}2.8 E-13 \\
2.5 E-12\end{array}$ & & & & & & & \\
\hline & & & & $0-14$ & $2.6 E-04$ & $1.0 \mathrm{E}-03$ & & & & & & $2.6 \mathrm{E}-09$ & & & & & & & \\
\hline & & & & $\begin{array}{l}\text { SS-134 } \\
\text { Ba-133 }\end{array}$ & $\begin{array}{l}\frac{3.1 \mathrm{E}-08}{2.0 \mathrm{E}-09} \\
\end{array}$ & $\begin{array}{l}\frac{1.0 \mathrm{E}-03}{1.0 \mathrm{E}-03} \\
\end{array}$ & & & & & & $\begin{array}{l}3 . \mathrm{E}-13 \\
2.0 \mathrm{E}-14\end{array}$ & & & & & & & \\
\hline & & & & $\frac{\text { P.-32 }}{\text { Pu-238 }}$ & $\begin{array}{l}3.3 \mathrm{~B}-06 \\
1.8 \mathrm{E}-09\end{array}$ & $\begin{array}{l}\frac{1.0 \mathrm{E}-03}{1.0 \mathrm{E}-03} \\
\end{array}$ & & & & & & $\begin{array}{l}\frac{3.3 \mathrm{E}-11}{1.8 \mathrm{E}-14} \\
\end{array}$ & & & & & & & \\
\hline & & & & Pu-239 & & 3 & & & & & & $1.4 E-12$ & & & & & & & \\
\hline & & & & Am-241 & $\begin{array}{l}2.1 E-08 \\
4.2 E-08\end{array}$ & $\begin{array}{l}1.06-03 \\
1.0 E-03\end{array}$ & & & & & & $\begin{array}{l}\frac{2.1 .1-13}{4.2 E-13} \\
\end{array}$ & & & & & & & \\
\hline & & & & 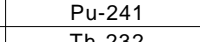 & 1.3E-06 & $\begin{array}{l}1.0 E-03 \\
1.050 \\
\end{array}$ & & & & & & $1.3 \mathrm{E}$ & & & & & & & \\
\hline & & & & Pu-242 & $\begin{array}{l}4.05-09 \\
7.15-07\end{array}$ & $\begin{array}{l}1.0 E-03 \\
1.0 E-03 \\
\end{array}$ & & & & & & $\begin{array}{l}4.0 \mathrm{~L}-14 \\
7.1 \mathrm{E}-12\end{array}$ & & & & & & & \\
\hline 514 & 108 & Room Air & Vacuum filtration of treated & Am-241 & $4.6 E-05$ & $1.00 E-03$ & $\mathrm{NA}$ & $N A$ & $\mathrm{NA}$ & None & 1 & $\begin{array}{l}4.6 E-08 \\
\end{array}$ & 528 & NE & $2.2 E-04$ & 217 & SW & $6.6 E-04$ & 1 \\
\hline & & & waste water & $\begin{array}{ll}\text { Am-243 } \\
\text { Ba-133 }\end{array}$ & $\begin{array}{l}\frac{1.9 \mathrm{G}-06}{1.7 \mathrm{E}-06} \\
\end{array}$ & $\begin{array}{l}\frac{1.00 E-03}{1.00 E-03} \\
\end{array}$ & & & & & & $\begin{array}{l}\frac{1.96-09}{1.75-09} \\
\end{array}$ & & & & & & & \\
\hline & & & & $\frac{B i-207}{C-14}$ & $\begin{array}{l}1.2 E-07 \\
125=06\end{array}$ & $\begin{array}{l}1.00 E-03 \\
1.00-03\end{array}$ & & & & & & $1.2 \mathrm{E}$ & & & & & & & \\
\hline & & & & Cd 1409 & $\frac{1.2}{3.2}-20>0$ & 1.00E-03 & & & & & & & & & & & & & \\
\hline & & & & Ce-144 & $1.2 E-05$ & $\begin{array}{l}1.00 E-03 \\
.00-00\end{array}$ & & & & & & 1.2E-08 & & & & & & & \\
\hline & & & & Cm-244 & & $\begin{array}{l}1.00-03 \\
1.00-03\end{array}$ & & & & & & 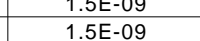 & & & & & & & \\
\hline & & & & $00-56$ & $1.2 \mathrm{E}-08$ & $1.00 E-03$ & & & & & & & & & & & & & \\
\hline & & & & Co-58 & $5.8-4>0$ & 03 & & & & & & 5.8E-11 & & & & & & & \\
\hline & & & & Co-60 & $5.6 \mathrm{E}-06$ & $1.00 E-03$ & & & & & & $5.6 \mathrm{E}-09$ & & & & & & & \\
\hline
\end{tabular}


Attachment 1 - 2000 LLNL NESHAPs Annual Report Spreadsheet

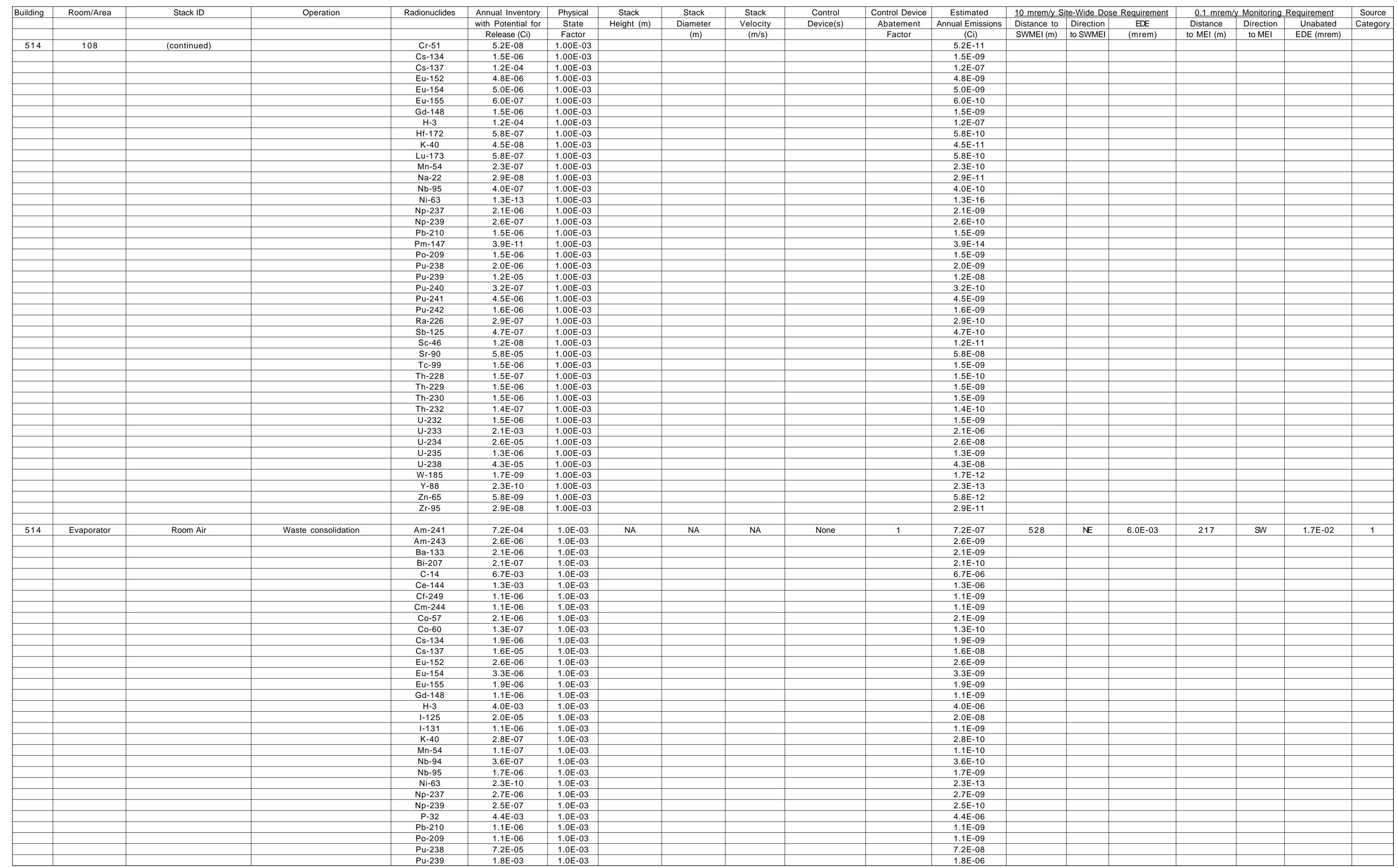


Attachment 1 - 2000 LLNL NESHAPs Annual Report Spreadsheet

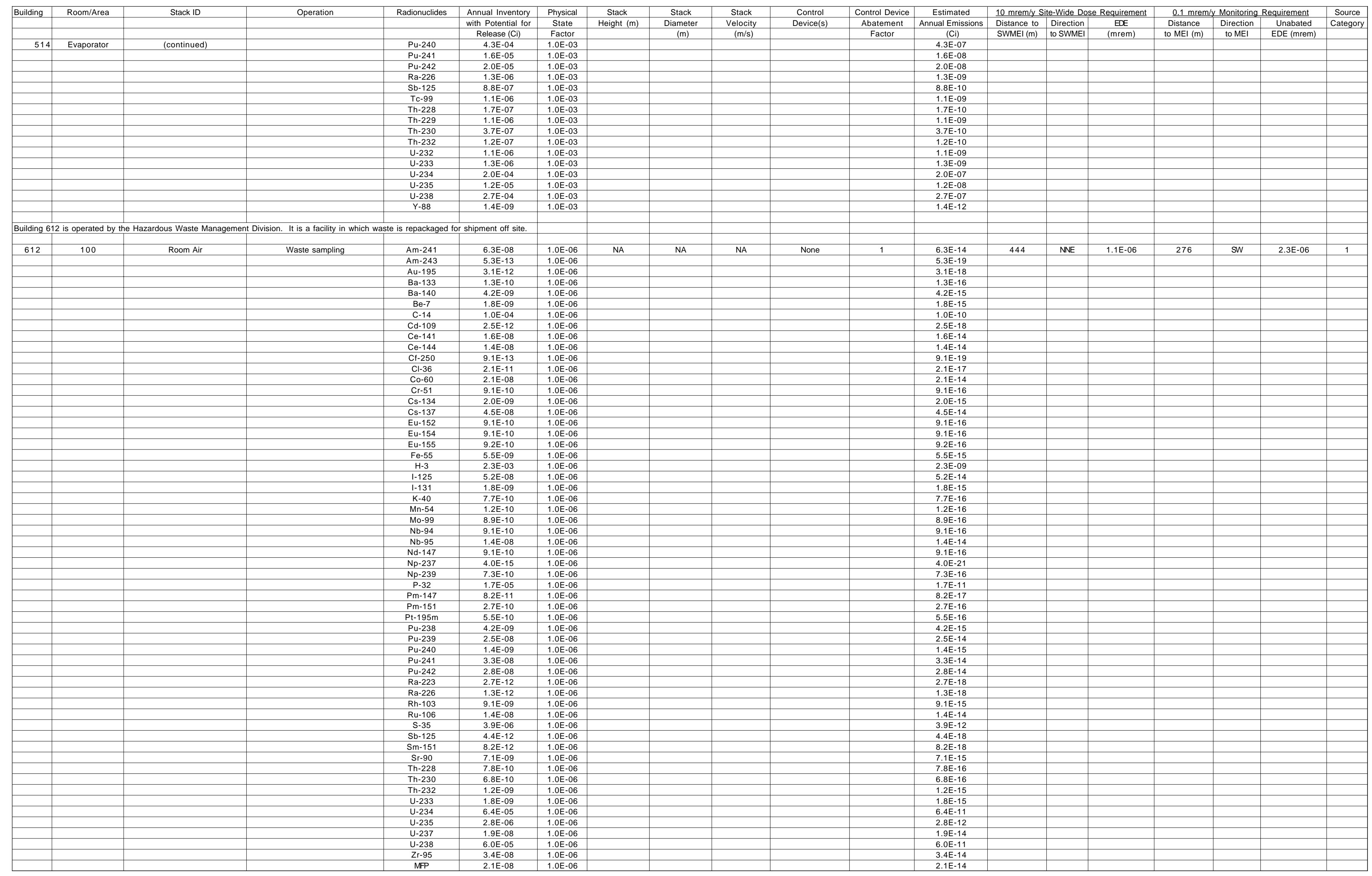


Attachment 1 - 2000 LLNL NESHAPs Annual Report Spreadsheet

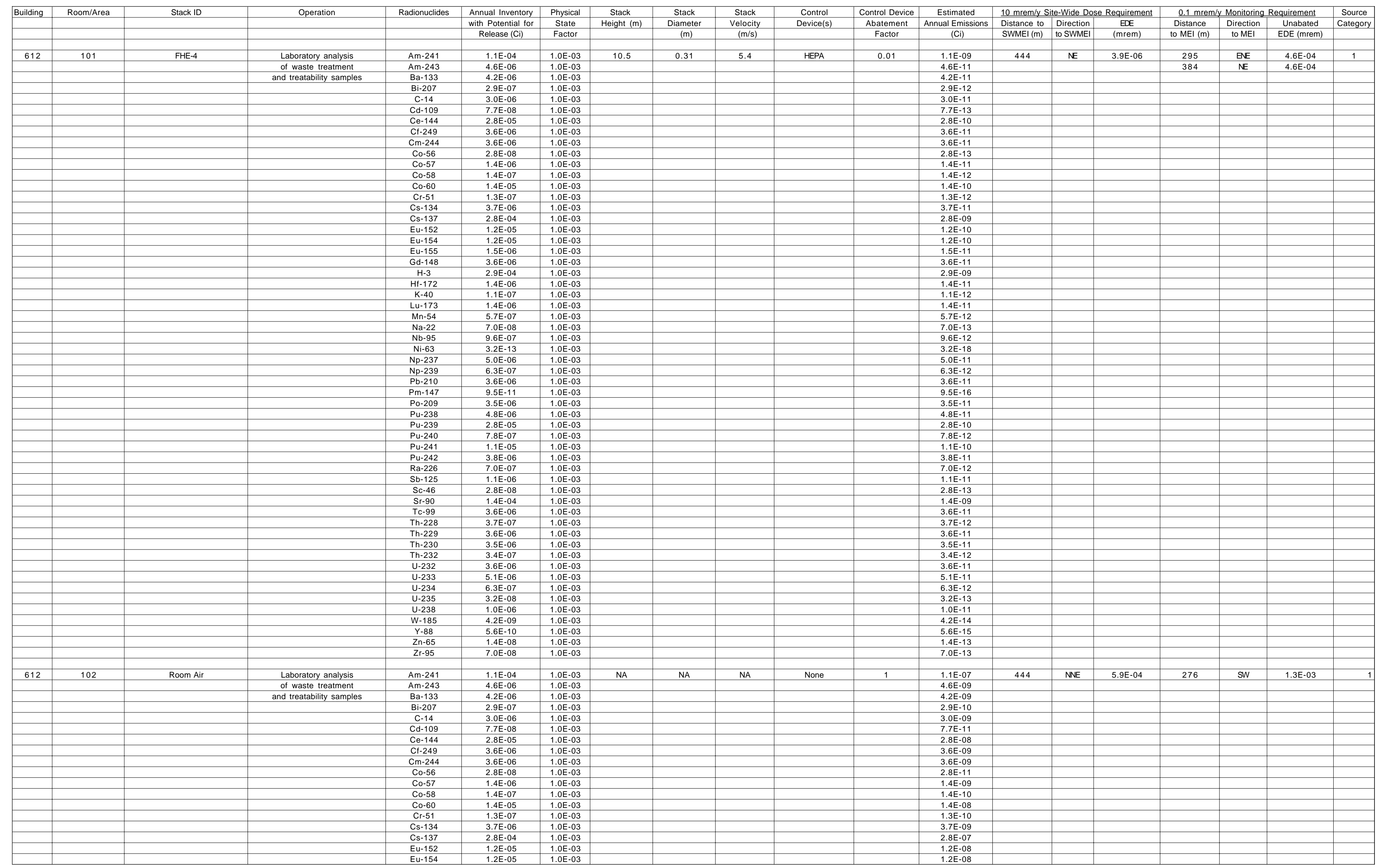


Attachment 1 - 2000 LLNL NESHAPs Annual Report Spreadsheet

\begin{tabular}{|c|c|c|c|c|c|c|c|c|c|c|c|c|c|c|c|c|c|c|c|}
\hline Building & Room/Area & Stack ID & Operation & Radionuclides & \begin{tabular}{|l|} 
Annual Inventory \\
with Potential for \\
\end{tabular} & \begin{tabular}{|c|} 
Physical \\
State \\
\end{tabular} & \begin{tabular}{|c|} 
Stack \\
Height (m)
\end{tabular} & $\begin{array}{c}\text { Stack } \\
\text { Diameter } \\
\text { (m) }\end{array}$ & $\begin{array}{c}\text { Stack } \\
\text { Velocity } \\
\text { Vo(ty }\end{array}$ & $\begin{array}{c}\text { Control } \\
\text { Device(s) } \\
\end{array}$ & \begin{tabular}{|c|} 
Control Device \\
Abatement \\
\end{tabular} & \begin{tabular}{|c} 
Estimated \\
Annual Emissions
\end{tabular} & $\frac{10 \text { mrem/s }}{\text { Distance }}$ & 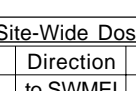 & $\begin{array}{c}\text { se Requirement } \\
\text { DE }\end{array}$ & $\begin{array}{l}\frac{0.1 \mathrm{mrem}}{\text { Distance }} \\
\text { D. }\end{array}$ & \begin{tabular}{|l|l|l|l|l} 
Monitoring F \\
Direction
\end{tabular} & $\begin{array}{l}\text { Requirement } \\
\text { Unabated } \\
\text { Unfored }\end{array}$ & $\begin{array}{l}\text { Source } \\
\text { Cautegory }\end{array}$ \\
\hline 612 & 102 & (continued) & & Eu-155 & & \begin{tabular}{|l|} 
Factor \\
$10-03$
\end{tabular} & & & & & & & & & & & & & \\
\hline & & (continuea) & & Gd-148 & $\begin{array}{l}3.6 \mathrm{E}-06 \\
3.6 \mathrm{E}-06\end{array}$ & $\begin{array}{ll}1.0 E-03 \\
1.0 E-03 \\
\end{array}$ & & & & & & $\begin{array}{r}1.5 \mathrm{E}-\mathrm{C} 9 \\
3.6 \mathrm{E}-09 \\
\end{array}$ & & & & & & & \\
\hline & & & & $\mathrm{H}-3$ & $2.9 \mathrm{E}-04$ & 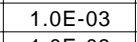 & & & & & & $2.9 \mathrm{E}-07$ & & & & & & & \\
\hline & & & & $\frac{H F-172}{K K-40}$ & 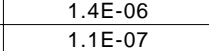 & \begin{tabular}{|l|}
$1.0 \mathrm{E}-03$ \\
$1.0 \mathrm{E}-03$ \\
\end{tabular} & & & & & & $\frac{1.4 \mathrm{E}-99}{1.11-10}$ & & & 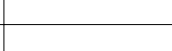 & & & & \\
\hline & & & & Lu-173 & $\begin{array}{l}1.4 \mathrm{~L}-06 \\
5.7 \mathrm{~F}-07\end{array}$ & \begin{tabular}{|l|}
$1.0 \mathrm{E}-03$ \\
$1.0 \mathrm{O}-\mathrm{s}$ \\
\end{tabular} & & & & & & $\begin{array}{l}1.4 E-09 \\
5.77-10\end{array}$ & & & & & & & \\
\hline & & & & $\begin{array}{ll}\mathrm{Na}-22 \\
\mathrm{Nb}-95\end{array}$ & $\begin{array}{l}7.0 \mathrm{D}-08 \\
960-07\end{array}$ & \begin{tabular}{|l|l|}
$1.0 E-03$ \\
$1.00-03$
\end{tabular} & & & & & & $\begin{array}{l}7.0-11 \\
96-11 \\
9.6-10\end{array}$ & & & & & & & \\
\hline & & & & $\begin{array}{ll}\mathrm{Ni}-63 \\
\mathrm{No}-237 \\
-1237\end{array}$ & $\begin{array}{l}3.2 E-13 \\
5.0-06\end{array}$ & \begin{tabular}{|l|l|}
$1.0 E-03$ \\
$1.00-03$
\end{tabular} & & & & & & $\begin{array}{l}3.2-2-16 \\
5500-09\end{array}$ & & & & & & & \\
\hline & & & & $\begin{array}{ll}\frac{N p-239}{\mathrm{Nop}} \\
\mathrm{Pb}-210\end{array}$ & $\begin{array}{l}6.3 E-07 \\
3.36-06\end{array}$ & \begin{tabular}{|l|}
$1.0 \mathrm{E}-03$ \\
$10 \mathrm{O}-\mathrm{-}-3$
\end{tabular} & & & & & & $\begin{array}{l}6.3 E-10 \\
365-09\end{array}$ & & & & & & & \\
\hline & & & & $\mathrm{Pm}-147$ & $\begin{array}{l}9.5 E-11 \\
9.05-00\end{array}$ & \begin{tabular}{|l|l|}
$1.0 E-03$ \\
\end{tabular} & & & & & & $\begin{array}{l}9.5 E-14 \\
9.5-14\end{array}$ & & & & & & & \\
\hline & & & & $\begin{array}{l}\text { Po-2099 } \\
\text { Pu-238 }\end{array}$ & $\begin{array}{l}3.5 E-06 \\
4.8-06\end{array}$ & $\begin{array}{l}1.0 \mathrm{E}-03 \\
1.0 \mathrm{E}-03\end{array}$ & & & & & & $\begin{array}{l}3.5 E-09 \\
48=09\end{array}$ & & & & & & & \\
\hline & & & & Pu-239 & $2.8 \mathrm{E}-05$ & $\begin{array}{ll}1.0 \mathrm{E}-03 \\
\end{array}$ & 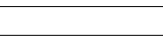 & & & & & $2.8 \mathrm{E}-08$ & & & & & & & \\
\hline & & & & & 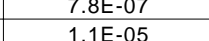 & $\begin{array}{l}1.0 E=03 \\
1.0 E-03\end{array}$ & & & & & & & & & & & & & \\
\hline & & & & Pu-242 & $3.8 \mathrm{E}-06$ & \begin{tabular}{|c|}
$1.0 E-03$ \\
\end{tabular} & & & & & & $3.8 \mathrm{E}-09$ & & & & & & & \\
\hline & & & & $\begin{array}{ll}\frac{\pi}{2 a-26} \\
\text { Sb-125 }\end{array}$ & 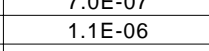 & \begin{tabular}{|l|}
$1.0 E-0$ \\
$1.05-03$ \\
\end{tabular} & 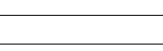 & 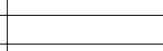 & 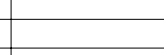 & & & 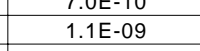 & & & & & & & \\
\hline & & & & $\frac{S c-46}{\text { Sr-90 }}$ & $\begin{array}{l}2.8 \mathrm{E}-08 \\
1.4 \mathrm{E}-04\end{array}$ & \begin{tabular}{|l|}
$1.0 E-33$ \\
$1.0 E-03$ \\
\end{tabular} & & & & & & $\begin{array}{l}2.8 \mathrm{E}-11 \\
1.4 \mathrm{E}-07\end{array}$ & & & & & & & \\
\hline & & & & $\begin{array}{l}\text { Tc-99 } \\
\text { Th-228 }\end{array}$ & $\begin{array}{l}3.6 E=-06 \\
375=07\end{array}$ & \begin{tabular}{|l|}
$1.0 \mathrm{E}-03$ \\
$10 \mathrm{E}-03$
\end{tabular} & & & & & & $\begin{array}{l}3.6 \mathrm{E}-09 \\
37 \mathrm{~F}-10\end{array}$ & & & & & & & \\
\hline & & & & Th-228 & $\begin{array}{ll}3.6 E-16 \\
3.6 E-06\end{array}$ & \begin{tabular}{|l|l|}
$.1 .0 E-03$ \\
1.003 \\
\end{tabular} & & & & & & $\begin{array}{l}3.6 \mathrm{E}-09 \\
3.09\end{array}$ & & & & & & & \\
\hline & & & & $\begin{array}{l}\text { Thh-230 } \\
\text { Th-32 }\end{array}$ & $\begin{array}{l}3.5 E-06 \\
3.4-0 .-07 \\
\end{array}$ & \begin{tabular}{|l|}
$1.0 \mathrm{E}-03$ \\
$1.0 \mathrm{E}-03$
\end{tabular} & & & & & & $\frac{3.5 \mathrm{E}-09}{3.4-10}$ & & & 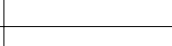 & & & & \\
\hline & & & & U-232 & $\begin{array}{l}3.6 \mathrm{E}-06 \\
5.6506\end{array}$ & \begin{tabular}{|l|l|}
$1.0-0.03$ \\
$1.0-032$
\end{tabular} & & & & & & $3.6 E-09$ & & & & & & & \\
\hline & & & & U-234 & $\begin{array}{ll}5 \\
5.0 E-06\end{array}$ & $\begin{array}{ll}1.0 E-03 \\
1.0 \mathrm{E}-03\end{array}$ & & & & & & & & & & & & & \\
\hline & & & & $\mathrm{U}-235$ & $3.2 \mathrm{E}-06$ & $1.0 \mathrm{E}-03$ & & & & & & $3.2 E-09$ & & & & & & & \\
\hline & & & & $\frac{\text { U-238 }}{\text { W-185 }}$ & 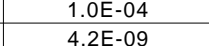 & $\begin{array}{l}1.0 \mathrm{E}-03 \\
1.0 \mathrm{E}-03\end{array}$ & & & & & & $\frac{1.0 E-07}{4.2 E-12}$ & & 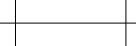 & & & & & \\
\hline & & & & $Y-88$ & $5.6 E-10$ & $1.0 \mathrm{E}-03$ & & & & & & $5.6 \mathrm{E}-13$ & & & & & & & \\
\hline & & & & $\frac{n z-65}{2 r-95}$ & $\begin{aligned} \frac{1}{1.4 L-08} \\
7.0 E-08\end{aligned}$ & \begin{tabular}{|l|}
$1.0 \mathrm{E}-03$ \\
$1.0 \mathrm{E}-03$ \\
\end{tabular} & & & & & & $\begin{array}{l}\frac{1.4 E-11}{7.0 E-11} \\
71\end{array}$ & & & & & & & \\
\hline Building 6 & 5 is operated by & Hazardous Waste Management. & & & & & & & & & & & & & & & & & \\
\hline 625 & Repack Tent & MHE & Waste inspection and repackaging & Am-241 & $2.0 E-11$ & $1.0 \mathrm{E}-03$ & 1.5 & 0.31 & 6.9 & HEPA & 0.01 & $2.0 E-16$ & 378 & NE & $3.8 \mathrm{E}-05$ & 289 & $\mathrm{ENE}$ & 4.4E-03 & 1 \\
\hline & & & & C-14 & $\begin{array}{l}1.1 \mathrm{E}-06 \\
\end{array}$ & $1.0 \mathrm{E}-03$ & & & & & & $1+51$. & & & & & & & \\
\hline & & & & $\begin{array}{c}\text { Ce-1444 } \\
\text { C- } 1473\end{array}$ & $\begin{array}{l}3.8 E-12 \\
35-12\end{array}$ & $\begin{array}{l}1.0 E-03 \\
1.02\end{array}$ & & & & & & $\begin{array}{l}3.8 E-17 \\
35-15\end{array}$ & & & & & & & \\
\hline & & & & Eu-152 & $\begin{array}{l}2.0 E-10 \\
1.9 E-11\end{array}$ & $\begin{array}{l}1.0=-03 \\
1.0 E-03 \\
\end{array}$ & 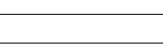 & 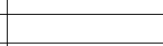 & 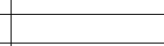 & & & 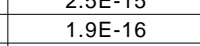 & & & & & & & \\
\hline & & & & $\frac{H-3}{\text { Pu-238 }}$ & $\begin{array}{l}9.2 E=04 \\
1.4-099\end{array}$ & $\begin{array}{l}1.0 \mathrm{E}-03 \\
10 \mathrm{E}-03\end{array}$ & & & & & & $\begin{array}{l}9.2 E-09 \\
1.4=-14\end{array}$ & & & & & & & \\
\hline & & & & Pu-239 & $8.7 E-11$ & $1.0 \mathrm{E}-03$ & -5 & - & & & & $8.7 \mathrm{E}-16$ & & & & & & & \\
\hline & & & & Th-232 & 告.6E-12 $13 \mathrm{E}-08$ & $\begin{array}{l}1.0 \mathrm{E}-03 \\
1.0 \mathrm{E}-03\end{array}$ & & & & & & 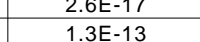 & & & & & & & \\
\hline & & & & U-234 & $1.3 \mathrm{E}-03$ & $1.0 \mathrm{E}-03$ & & & & & & $1.3 E^{-08}$ & & & & & & & \\
\hline & & 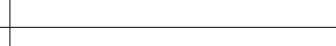 & & $\begin{array}{l}U-235 \\
11-238 \\
\end{array}$ & $\begin{array}{r}2.3 E-03 \\
18-07 \\
8.07\end{array}$ & $\begin{array}{l}1.0 E-03 \\
1.0 E-03\end{array}$ & & & & & & $\begin{array}{l}2.3 \mathrm{E}-08 \\
18 \mathrm{~B}-12\end{array}$ & & & & & & & \\
\hline & & & & & & & & & & & & & & & & & & & \\
\hline SITE 300 & OINT SOURCES & & & & & & & & & & & & & & & & & & \\
\hline Site 300 . & Explosives tests & Duclides $m$ & Icted & ables located at $\mathrm{Bu}$ & inkers 801 and 851 & These tests h & ave depleted ure & anium material a & art of the $\mathrm{ma}$ & terial inventory Ther & are muttinle test & Der vear & & & & & & & \\
\hline activa & in products are $\mathrm{c}$ & ted at the flash $x$-ray and LINA & 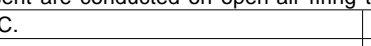 & Le & & & & & . & . & . & & & & & & & & \\
\hline $810 \mathrm{~A}$ & 109 & Room Air & Assembly of explosives & U-238 & 5.4E-02 & $1.0 \mathrm{E}-06$ & $N A$ & NA & $\mathrm{NA}$ & None & 1 & 5.4E-08 & 2360 & wsw & $2.8 \mathrm{E}-07$ & 944 & SSE & $6.7 \mathrm{E}-06$ & 1 \\
\hline & 133 & & test devices & $\frac{\text { U-2235 }}{\text { U-234 }}$ & $\begin{array}{l}6.9 E-04 \\
5.0 E-03\end{array}$ & $\begin{array}{l}1.0 \mathrm{E}-06 \\
1.0 \mathrm{E}-06\end{array}$ & & & & & & $\begin{array}{l}6.9 \mathrm{E}-10 \\
5.0 \mathrm{E}-09\end{array}$ & & & & & & & \\
\hline $810 \mathrm{~B}$ & 100 & Room Air & Assembly of explosives & U-238 & $1.6 \mathrm{E}-02$ & $1.0 \mathrm{E}-06$ & NA & $\mathrm{NA}$ & NA & None & 1 & $1.6 \mathrm{E}-08$ & 2410 & wsw & $7.8 E-08$ & 907 & SSE & $2.1 \mathrm{E}-06$ & 1 \\
\hline & & & & U-234 & 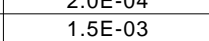 & 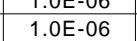 & & & & & & 1.5E-09 & & & & & & & \\
\hline 801 & 125 & FE-4 & Flash X-ray (FXR) & $N-1$. & $3.45-03$ & $1.0 E+00$ & $N A$ & NA & $\mathrm{NA}$ & None & 1 & $3.4 \mathrm{E}-03$ & 4114 & $s$ & $18 \mathrm{E}-08$ & 1809 & $\mathrm{BNE}$ & $36 E-07$ & 1 \\
\hline & & & & Ar-41 & $2.0 \mathrm{E}-07$ & $1.0 \mathrm{E}+00$ & & & & & & $2.0 \mathrm{E}-07$ & & & & & & & \\
\hline 851 & Firing Table & None & Explosive tests & U-238 & $1.5 \mathrm{E}-02$ & $1.0 E+00$ & NA & NA & NA & None & 1 & $1.5 \mathrm{E}-02$ & 3170 & SSE & $1.5 \mathrm{E}-02$ & 1396 & wsw & $2.0 E-02$ & 4 \\
\hline & & & & 甚-235 & 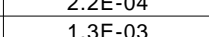 & 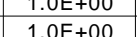 & & & & & & 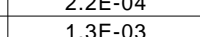 & & & & & & & \\
\hline
\end{tabular}


Attachment 1 - 2000 LLNL NESHAPs Annual Report Spreadsheet

\begin{tabular}{|c|c|c|c|c|c|c|c|c|c|c|c|c|c|c|c|c|c|c|c|}
\hline Building & Room/Area & Stack ID & Operation & Radionuclides & Annual Inventory & Physical & Stack & Stack & Stack & Control & Control Device & Estimated & $10 \mathrm{mrem} / \mathrm{s} \mathrm{S}$ & Site-Wide Dos & se Requirement & $0.1 \mathrm{mrem} / /$ & Monitoring & Requirement & Source \\
\hline & & & & & $\begin{array}{l}\text { With Potential tor } \\
\text { Releases (Ci) } \\
\end{array}$ & $\begin{array}{l}\text { State } \\
\text { Factor } \\
\end{array}$ & Height (m) & $\begin{array}{l}\frac{D}{\text { Diameter }} \\
(\mathrm{m})\end{array}$ & $\frac{V \text { velocity }}{(m) s)}$ & Device(s) & \begin{tabular}{l|} 
Abatement \\
Factor
\end{tabular} & \begin{tabular}{|l|} 
Annual Emissions \\
(Ci)
\end{tabular} & \begin{tabular}{|l|l} 
Distance to \\
swMMEI(m)
\end{tabular} & $\begin{array}{l}\text { Direction } \\
\text { to SWMEl } \\
\end{array}$ & $\begin{array}{ll}\text { DE } \\
\text { (mrem) }\end{array}$ & \begin{tabular}{|l|l} 
Distance \\
to MEl(m) \\
\end{tabular} & $\begin{array}{l}\text { Direction } \\
\text { to MEI } \\
\end{array}$ & $\begin{array}{l}\text { Unabated } \\
\text { EDE (merem) } \\
.\end{array}$ & ategory \\
\hline 851 & 111 & None & Linear accelerator & $\mathrm{N}-13$ & $8.2 E-02$ & $1.0 \mathrm{E}+00$ & NA & NA & $\mathrm{NA}$ & None & 1 & $8.2 E-02$ & 3170 & SSE & $1.6 E-06$ & 3836 & $\mathrm{ENE}$ & $2.1 E-06$ & 1 \\
\hline & & & & $\begin{array}{l}0-15 \\
\text { Ar-41 }\end{array}$ & $\begin{array}{l}7.6 \mathrm{E}-02 \\
15 \mathrm{E}-04\end{array}$ & $1.0 E+00$ & & & & & & $\begin{array}{l}7.6 E-02 \\
1.5-0.04\end{array}$ & & & & & & & \\
\hline & & & & & & & & & & & & & & & & & & & \\
\hline LVERMOF & ESTTE DIFFUSESC & OURCES & & & & & & & & & & & & & & & & & \\
\hline & - This ta & & & & & & & & & & & & & & & & & & \\
\hline 223 & Outside & None & Soil and gravel cleanup acativivies & $\begin{array}{l}\mathrm{Am}-244 \\
\mathrm{Am}-243 \\
\mathrm{n}\end{array}$ & $\frac{1.2 E-04}{16 E-06}$ & $\begin{array}{ll}1.0 E-06 \\
10 E-06\end{array}$ & NA & NA & NA & None & 1 & $\begin{array}{l}1.2 E-10 \\
1.6-12\end{array}$ & 1155 & ENE & 1.2E- -07 & $\frac{340}{313}$ & SSW & $\begin{array}{l}1.1 \mathrm{E}-06 \\
11-0.60\end{array}$ & 5 \\
\hline & & & & Pu-239 & $2.6 \mathrm{E}-04$ & $1.0 \mathrm{E}-06$ & & & & & & $\begin{array}{l}\frac{1.6 E-12}{2.6 E-10} \\
2.6-10\end{array}$ & & & & & & & \\
\hline illding 2 & - Diffuse emiss & is result from tritium-contaminat & $\mathrm{d}$ water which leaked from an unde & rground storage tan & Vegetation in the & area transpirs & es water with $€$ & ted tritium co & entrations. & & & & & & & & & & \\
\hline 292 & Spill Area & None & Evaporation and transpiration & $\mathrm{H}-3$ & NA & 1 & $\mathrm{NA}$ & NA & $\mathrm{NA}$ & None & 1 & $4.9 E-04$ & 1380 & ESE & $7.2 E-08$ & 456 & $\mathrm{~N}$ & $18 \mathrm{E}-06$ & 6 \\
\hline Building 3 & 1. As part of $D S$ & Doperations, contaminated equipt & ment outside the facility is awaiting tr & ansport and storage & e by Hazardous Wast & te Managemen & & & & & & & & & & 655 & w & $1.8 \mathrm{E}-06$ & \\
\hline $\begin{array}{ll}\text { Inte dos } \\
331\end{array}$ & $\begin{array}{l}\text { e from HTO emiss } \\
\text { Outside }\end{array}$ & $\begin{array}{c}\text { calculate } \\
\text { None }\end{array}$ & 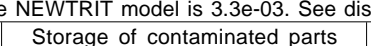 & $\begin{array}{l}n-3 \text { page } 1 \\
H-3\end{array}$ & NA & 1 & No & NA & 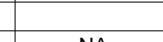 & & & 525000 & $007+7)$ & $5 \mathrm{Tr}, \mathrm{s}$ & & & & & \\
\hline & & & & & NA & & 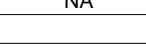 & & NAA & Tone & & $0 . \angle E+00$ & (951 & ENE & 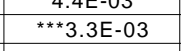 & 573 & sw & $\begin{array}{l}1.17-0 c^{2} \\
1.7 E-02\end{array}$ & \\
\hline 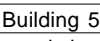 & 14 is operated by & e Hazardous Waste Managemen & t Division. The wastewater treatmen & $\mathrm{t}$ tank farm and stor & rage tank area proces & sses the liquid & waste from fa & ilities on site. T & he treatment prc & rocess may involve $b$ & chemical treatme & ment & & & & & & & \\
\hline consisting & of neutralization, & cculation, oxidation, reduction, p & receipitation, separation, and filtration. & Areas used for stc & torage are not conside & tered to releas & e radionuclides & because the wat & istes are fully co & & & & & & & & & & \\
\hline 514 & Tank Farm & Area Source & 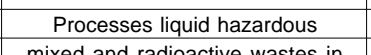 & Am-241 & $1.9 \mathrm{E}-04$ & $\begin{array}{ll}1.0 E-03 \\
1.0-02\end{array}$ & $\mathrm{NA}$ & NA & NA & None & 1 & $1.9 \mathrm{E}-07$ & 528 & NE & $9.2 \mathrm{E}-04$ & 217 & SW & $3.22-03$ & 5 \\
\hline & & & $\begin{array}{l}\text { mixed and radiaactive wastes Sin } \\
\text { open topped tanks. }\end{array}$ & $\begin{array}{l}\frac{A m-243}{B a-133} \\
\end{array}$ & $\begin{array}{l}7.99-06 \\
7.1 E-06 \\
\end{array}$ & $\begin{array}{l}1.0 E-03 \\
1.05-03 \\
\end{array}$ & & & & & & $\begin{array}{l}7.9 .9-09 \\
7.11-09 \\
\end{array}$ & & & & & & & \\
\hline & & & & $\frac{B i-207}{C-14}$ & $\begin{array}{l}4.9 E=-07 \\
5.2-0.06\end{array}$ & $\begin{array}{l}\frac{1.0 E-03}{1.0 E-03} \\
1.03\end{array}$ & & & & & & $\begin{array}{l}4.9 E-10 \\
52-09\end{array}$ & & & & & & & \\
\hline & & & & Cd-109 & $\begin{array}{l}0.250 \\
1.3 \mathrm{E}-07 \\
\end{array}$ & $\begin{array}{ll}1.05-03 \\
1.0 E-03 \\
T\end{array}$ & & & & & & $\begin{array}{l}0.3 E-10 \\
1.30\end{array}$ & & & & & & & \\
\hline & & & & $\begin{array}{l}\text { Ce-144 } \\
\text { Ct-249 }\end{array}$ & $\begin{array}{l}\frac{4.88-5}{6.2 E-06} \\
\end{array}$ & $\begin{array}{l}\frac{1.0 E-03}{1.0 E-03} \\
\end{array}$ & & & & & & \begin{tabular}{|l|}
$4.8 E-08$ \\
$6.2 E-09$ \\
\end{tabular} & & & & & & & \\
\hline & & & & $\frac{C m-244}{C_{0}-56}$ & 6.2E-06 & 03 & & & & & & \begin{tabular}{|l|}
$6.2 E-99$ \\
$48-11$
\end{tabular} & & & & & & & \\
\hline & & & & $0 .-57$ & $2.4 \mathrm{E}-06$ & 1.0E-03 & & & & & & $2.4 \mathrm{E}-09$ & & & & & & & \\
\hline & & & & $\begin{array}{l}\frac{0.58}{00.60} \\
0.50\end{array}$ & $\begin{array}{l}2.4 \mathrm{EE}-05 \\
2.3 \mathrm{E}-07\end{array}$ & $\begin{array}{l}\frac{1.0 E-03}{1.0 E-03} \\
1.03\end{array}$ & & & & & & $\begin{array}{l}2.4 E-08 \\
2.3 E-10\end{array}$ & & & & & & & \\
\hline & & & & Cr-51 & $2.2 E-07$ & $1.0 \mathrm{E}-03$ & & & & & & $2.2 E-10$ & & & & & & & \\
\hline & & & & $\frac{C s-134}{C s-137}$ & $\begin{array}{ll}6.3-3 E-06 \\
30-54\end{array}$ & $\begin{array}{l}1.0 \mathrm{E}-03 \\
1.0 \mathrm{E}-03\end{array}$ & & & & & & 6.3-3-099 & & & & & & & \\
\hline & & & & Eu-152 & $2.0 \mathrm{E}-05$ & $1.0 E-03$ & & & & & & $2.0 \mathrm{E}-08$ & & & & & & & \\
\hline & & & & $\begin{array}{l}\text { Eut-154 } \\
\text { Euv1 } 155\end{array}$ & $\begin{array}{l}2.1 E=05 \\
2.5-0 .-06 \\
\end{array}$ & $\begin{array}{l}\frac{1.0 \mathrm{E}-03}{1.0 \mathrm{E}-03} \\
\end{array}$ & & & & & & $\frac{2.15-8}{2.5 E-09}$ & & & & & & & \\
\hline & & & & $\frac{G d-148}{H-3}$ & $\begin{array}{l}6.2 E-06 \\
50=504\end{array}$ & $\begin{array}{ll}1.0 E-03 \\
1.05-03\end{array}$ & & & & & & 6.2E-09 & & & & & & & \\
\hline & & & & $\frac{H-3}{H F-172}$ & $\begin{array}{l}5.0 E=-04 \\
2.4-06\end{array}$ & $\begin{array}{l}1.06-03 \\
10 E-03\end{array}$ & & & & & & $\begin{array}{l}5.0 E=-07 \\
24-09\end{array}$ & & & & & & & \\
\hline & & & & $k-40$ & $1.96-07$ & $1.0 \mathrm{E}-03$ & & & & & & $1.95-10$ & & & & & & & \\
\hline & & & & $\frac{2 u-1 / 3}{\text { Mn-54 }}$ & $\begin{array}{l}2.4 E-06 \\
9.7=-07\end{array}$ & $\begin{array}{l}1.0 E-03 \\
1.0 E-03\end{array}$ & & & & & & $\begin{array}{l}2.4 E-09 \\
9.7-10-10\end{array}$ & & & & & & & \\
\hline & & & & $\mathrm{Na}-22$ & $1.2 E-07$ & $1.0 \mathrm{E}-03$ & & & & & & $1.2 \mathrm{E}-10$ & & & & & & & \\
\hline & & & & Nis-63 & 1.1. & 1.0E-03 & & & & & & $\begin{array}{l}5.45-16 \\
5.4-16\end{array}$ & & & & & & & \\
\hline & & & & Np-237 & 8.6E-06 & $1.0 E-03$ & & & & & & $8.6 E-09$ & & & & & & & \\
\hline & & & & $\begin{array}{l}\mathrm{Npp-239} \\
\mathrm{Pb}-210\end{array}$ & $\begin{array}{l}1.1 .1-06 \\
6.2 E-06\end{array}$ & $\begin{array}{l}\frac{1.0 E-03}{1.0 E-03} \\
1.03\end{array}$ & & & & & & $\begin{array}{l}1.1 E-09 \\
6.2-09\end{array}$ & & & & & & & \\
\hline & & & & & & 3 & & & & & & $1.6 \mathrm{E}-13$ & & & & & & & \\
\hline & & & & $\begin{array}{l}\text { Po-2099 } \\
\text { Pu-238 }\end{array}$ & $\begin{array}{l}6.0 E=06 \\
8.2 E-06\end{array}$ & 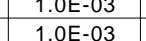 & & & & & & $8.2 E-09$ & & & & & & & \\
\hline & & & & $\begin{array}{l}\text { Pu-239 } \\
\text { D.220 }\end{array}$ & $\begin{array}{l}4.8 E-05 \\
.350 .66\end{array}$ & $\begin{array}{ll}1.0 E-03 \\
1.050 .03\end{array}$ & & & & & & $4.8 E-08$ & & & & & & & \\
\hline & & & & Pu-240 & $1.9 E-05$ & $\begin{array}{l}1.0 E-03 \\
1.0 E-03\end{array}$ & & & & & & & & & & & & & \\
\hline & & & & $\begin{array}{l}\text { Pu-242 } \\
\text { Ba-2269 }\end{array}$ & $\begin{array}{l}6.5 E-06 \\
125-06\end{array}$ & $\begin{array}{ll}1.0 \mathrm{E}-03 \\
1.0 \mathrm{E}-03\end{array}$ & & & & & & $\begin{array}{l}6.5 \mathrm{E}-09 \\
.2509\end{array}$ & & & & & & & \\
\hline & & & & Sb- 125 & $2.05-06$ & 1.0E-03 & & & & 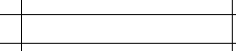 & & 2.0E-09 & & & & & & & \\
\hline & & & & 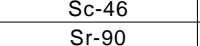 & $\begin{array}{l}08 \\
04\end{array}$ & $\begin{array}{l}1.0 E-03 \\
1.0 E-03\end{array}$ & & & & & & $4.8 \mathrm{~s}-2 \mathrm{x}$ & & & & & & & \\
\hline & & & & Tc-99 & $6.2 \mathrm{E}-06$ & $\begin{array}{l}1.0 \mathrm{E}-03 \\
1.03\end{array}$ & & & & & & 6 & & & & & & & \\
\hline & & & & Th-228 & & $1.0 \mathrm{E}-03$ & & & & & & & & & & & & & \\
\hline & & & & Th-2299 & $\begin{array}{l}6.2 E-06 \\
6.0=06\end{array}$ & $\begin{array}{l}1.0 E-03 \\
1.0 F(3)\end{array}$ & & & & & & $\begin{array}{l}6.62 \mathrm{~L}-09 \\
6.09\end{array}$ & & & & & & & \\
\hline & & & & Th-232 & $5.8 \mathrm{E}-07$ & $\begin{array}{ll}1.05-03 \\
\end{array}$ & & & & & & $\begin{array}{l}5.8 E-10 \\
5.85-29\end{array}$ & & & & & & & \\
\hline & & & & $\frac{u-232}{U-333}$ & $\begin{array}{l}6.2 E=-06 \\
8.7-0.06\end{array}$ & $\begin{array}{l}1.0 E-03 \\
1.0 E-03\end{array}$ & & & & & & $\begin{array}{l}6.2 E=-09 \\
8.7-09\end{array}$ & & & & & & & \\
\hline & & & & & & $1.0 \mathrm{E}-03 \mathrm{H}$ & & & & & & & & & & & & & \\
\hline & & & & u-235 & $5.5 E-06$ & $\begin{array}{l}1.0 \mathrm{E}-03 \\
\end{array}$ & & & & & & $5.5 E-09$ & & & & & & & \\
\hline
\end{tabular}


Attachment 1 - 2000 LLNL NESHAPs Annual Report Spreadsheet

\begin{tabular}{|c|c|c|c|c|c|c|c|c|c|c|c|c|c|c|c|c|c|c|c|}
\hline Building & Room/Area & Stack ID & Operation & Radionuclides & Annual Inventory & $\begin{array}{l}\text { Physical } \\
\text { hyical }\end{array}$ & Stack & Stack & Stack & Control & Control Device & $\begin{array}{l}\text { Estimated } \\
\text { nnut| }\end{array}$ & $\frac{10 \mathrm{mrem} / \mathrm{y} \mathrm{S}}{\text { Distane the }}$ & 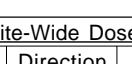 & $\begin{array}{l}\text { se Requirement } \\
\text { REF }\end{array}$ & $\frac{0.1 \mathrm{mrem} / \mathrm{y}}{\text { D. }}$ & Monitoring & $\begin{array}{l}\text { Requirement } \\
\text { Innhator }\end{array}$ & Source \\
\hline & & & & & $\begin{array}{l}\text { with Potential for } \\
\text { Release (Ci) }\end{array}$ & $\begin{array}{l}\text { State } \\
\text { Factor }\end{array}$ & Height (m) & Diameter & $\frac{\text { Velocity }}{(m / s)}$ & & $\begin{array}{l}\text { Abatement } \\
\text { Factor } \\
\end{array}$ & $\begin{array}{l}\text { Annual Emissions } \\
\text { (Ci) }\end{array}$ & $\begin{array}{l}\text { Distance to } \\
\text { SWMEI (m) }\end{array}$ & $\begin{array}{l}\text { irection } \\
\text { to sWMEl }\end{array}$ & $\begin{array}{c}\text { DE } \\
\text { (mrem) }\end{array}$ & & $\begin{array}{l}\text { Diection } \\
\text { to MEI }\end{array}$ & \begin{tabular}{|l} 
Unabated \\
EDE (mrem)
\end{tabular} & \\
\hline 514 & Tank Farm & (continued) & & $\begin{array}{l}u-238 \\
1495\end{array}$ & 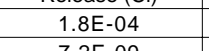 & $1.0 \mathrm{E}-03$ & & & & & & $1.8 \mathrm{E}-07$ & & & & & & & \\
\hline & & & & 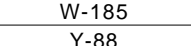 & $\begin{array}{l}7.2 \mathrm{E}=-09 \\
96 \mathrm{GE}-10\end{array}$ & $\begin{array}{l}1.0 \mathrm{E}-03 \\
100-03\end{array}$ & & & & & & $\begin{array}{l}7.2 \mathrm{E}-12 \\
96 \mathrm{E}-13 \\
-13\end{array}$ & & & & & & & \\
\hline & & & & $2 \mathrm{n}-65$ & $2.4 \mathrm{E}-08$ & $\begin{array}{l}1.00-0.5 \\
1.0 E-03 \\
\end{array}$ & & & & & & $\begin{array}{l}2.4 E-11 \\
2.45-11\end{array}$ & & & & & & & \\
\hline & & & & Zr-95 & 1.2E-07 & $1.0 E-03$ & & & & & & $1.2 E-10$ & & & & & & & \\
\hline ne Buildi & 9612 Yard is op & rated by the Hazardous Waste $M$ & anagement Division. The Yard consis & $s$ of several areas $v$ & & & & red outdoors. & e containers, $\mathrm{v}$ & & & & & & & & & & \\
\hline $\begin{array}{l}\text { The drun } \\
\text { The de do: }\end{array}$ & $\begin{array}{l}\text { sampling operati } \\
\text { fartrom HT emis }\end{array}$ & $\begin{array}{l}\text { place at all site Waste Ac } \\
\text { mate calculted using the }\end{array}$ & $\begin{array}{c}\text { cumulation Areas. Inventories were } \\
\text { ENEWTRIT model is } 1.1 \mathrm{e}-02 \text {. See e }\end{array}$ & $\begin{array}{l}\text { ombined and model } \\
\text { cussion on paga } 11\end{array}$ & ed as if the operation & occurred at & ne center of the & site. & & & & & & & & & & & \\
\hline 612 & Yard & Area Source & Storage of low level waste & $\mathrm{H}-3$ & NA & NA & $\mathrm{NA}$ & $\mathrm{NA}$ & NA & None & 1 & $3.6 \mathrm{E}+00$ & 444 & $\frac{N E}{1150}$ & $1.5 \mathrm{E}-02$ & 276 & sw & $4.5 \mathrm{E}-02$ & 6 \\
\hline 612 & All WAAs" ${ }^{*}$ & Area source & Drum sampling in & Am-241 & 4.1E-10 & $1.0 \mathrm{EE}-03$ & NA & NA & NA & None & 1 & $4.1 E-13$ & 951 & ESE & $8.5 \mathrm{E}-09$ & 969 & w & $5.1 \mathrm{E}-08$ & \\
\hline & & & $\begin{array}{l}612 \text { yard and all LLNL Waste } \\
\text { Accumulation Areas (WAAs) }\end{array}$ & Am-243 & $\begin{array}{l}1.5 E-11 \\
8.5-13\end{array}$ & $\begin{array}{l}\frac{1.0 \mathrm{E}-03}{1.0 \mathrm{D}-03} \\
\end{array}$ & & & & & & $\frac{1.5 \mathrm{E}-14}{8.5 \mathrm{E}-16}$ & & & & & & & \\
\hline & & & & $\mathrm{C}-14$ & $1.2 \mathrm{E}-09$ & $1.0 \mathrm{E}-03$ & & & & & & $1.2-12$ & & & & & & & \\
\hline & & & & $\frac{\text { Ce-144 }}{\text { Co. } 57}$ & $\begin{array}{l}\frac{1.2 E-10}{2.4 E-12} \\
2.51\end{array}$ & $\begin{array}{l}1.0 .0-5=3 \\
1.0 E-03\end{array}$ & & & & & & 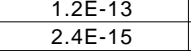 & & & & & & & \\
\hline & & & & $\frac{00.60}{\text { Css } 134}$ & $\frac{6.8 \mathrm{E}-12}{4.8 \mathrm{E}-11}$ & $\begin{array}{l}1.0 \mathrm{OE}-03 \\
1.0 \mathrm{E}-03\end{array}$ & & & & & & $\begin{array}{l}6.8 \mathrm{E}-15 \\
4.8 \mathrm{E}-14\end{array}$ & & & & & & & \\
\hline & & & & $\begin{array}{ll}\text { Cs }-137 \\
5-152\end{array}$ & $3.0 E-10$ & $1.0 \mathrm{E}-03$ & & & & & & $3.0 E-13$ & & & & & & & \\
\hline & & & & $\begin{array}{l}\text { Eu-152 } \\
\text { Eu-154 }\end{array}$ & $\begin{array}{l}4.9 E-11 \\
4.9 E-11\end{array}$ & $\begin{array}{l}1.0 .0-5=3 \\
1.0 E-03\end{array}$ & & & & & & 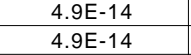 & & & & & & & \\
\hline & & & & $\begin{array}{ll}E u-155 \\
H \\
H\end{array}$ & $\begin{array}{l}3.6 \mathrm{E}-\mathrm{E}-2 \\
1.0 \mathrm{E}-05\end{array}$ & $\begin{array}{l}1.00-03 \\
1.0 E-03 \\
\end{array}$ & & & & & & $\begin{array}{l}3.6 E-15 \\
1.0 E-08\end{array}$ & & & & & & & \\
\hline & & & & K-40 & $3.3 \mathrm{E}-11$ & $1.0 \mathrm{E}-03$ & & & & & & $\begin{array}{l}3.3 E-14 \\
.35-15\end{array}$ & & & & & & & \\
\hline & & & & $\begin{array}{l}\text { Mnn-54 } \\
\text { Nb-95 }\end{array}$ & $\begin{array}{l}2.3 E-12 \\
1.2 E-12\end{array}$ & $\begin{array}{l}1.00-03 \\
1.0 E-03 \\
\end{array}$ & & & & & & $\begin{array}{l}2.3 E-15 \\
1.2 E-15\end{array}$ & & & & & & & \\
\hline & & & & $\frac{\mathrm{Ni}-63}{\mathrm{No}-239}$ & $\frac{9.5 E-11}{2.5 E-12}$ & $\begin{array}{l}1.0 \mathrm{OE}-03 \\
10 \mathrm{EO}-03\end{array}$ & & & & & & $\frac{9.5 E-14}{2.5 E-15}$ & & & & & & & \\
\hline & & & & $P-32$ & $\begin{array}{l}2.35-12 \\
7.4 \mathrm{E}-07 \\
\end{array}$ & $\begin{array}{l}1.06=03 \\
1.0 E-03\end{array}$ & & & & & & $\begin{array}{l}2.5 E-15 \\
7.4 E-10\end{array}$ & & & & & & & \\
\hline & & & & $\begin{array}{l}\text { Pu-238 } \\
\text { Pu-239 }\end{array}$ & $\begin{array}{l}\frac{1.1 E-12}{1.4 \mathrm{E}-10} \\
\end{array}$ & $\begin{array}{l}1.00-03 \\
1.0 E-03 \\
\end{array}$ & & & & & & $\begin{array}{l}\frac{1.1 E-15}{1.4 E-13} \\
\end{array}$ & & & & & & & \\
\hline & & & & $\begin{array}{l}\text { Pu-240 } \\
\text { Puu241 }\end{array}$ & $\begin{array}{l}9.5 \mathrm{E}-12 \\
3.1 \mathrm{E}-10\end{array}$ & $\begin{array}{l}1.0 \mathrm{OE}-03 \\
10 \mathrm{EO}-03\end{array}$ & & & & & & $\begin{array}{l}9.5 \mathrm{E}-\mathrm{-1} \\
3.1 \mathrm{E}-13\end{array}$ & & & & & & & \\
\hline & & & & $\begin{array}{l}\text { Pu-242 } \\
\text { Ra-226 }\end{array}$ & $\begin{array}{l}\frac{4.8 \mathrm{E}-11}{1.1 \mathrm{E}-12} \\
\end{array}$ & $\begin{array}{l}\frac{1.0 E-03}{1.00-03} \\
10.03\end{array}$ & & & & & & $\begin{array}{l}4.8 \mathrm{E}-14 \\
1.15-15\end{array}$ & & & & & & & \\
\hline & & & & $\frac{S b-125}{\text { St-90 }}$ & $\begin{array}{l}3.6 E-12 \\
1.5 E-13\end{array}$ & $\begin{array}{l}1.0 \mathrm{E}-03 \\
10.03\end{array}$ & & & & & & $\begin{array}{l}3.6 E-15 \\
3.14-16\end{array}$ & & & & & & & \\
\hline & & & & Tc-99 & $\begin{array}{l}1.4-13 \\
1.1 \mathrm{E}-11 \\
\end{array}$ & $1.0 \mathrm{E}-03$ & & & & & & $\begin{array}{l}\frac{1.42-16}{1.1 E-14} \\
\end{array}$ & & & & & & & \\
\hline & & & & $\begin{array}{l}\text { Th-228 } \\
\text { Th-230 }\end{array}$ & $\begin{array}{l}6.5 E-12 \\
5.5 E-14\end{array}$ & $\begin{array}{l}1.00-03 \\
1.0 E-03\end{array}$ & & $-C_{-1}$ & & & & $\frac{6.55-15}{5.5 E-17}$ & & - & & & & & \\
\hline & & & & Th-232 & 1.0E-12 & $1.0 E-03$ & & & & & & $1.0 E-15$ & & & & & & & \\
\hline & & & & $\frac{U-234}{U-235}$ & $\begin{array}{l}1.7 \mathrm{~F}-08 \\
23 \mathrm{E}-09\end{array}$ & 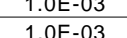 & & & & & & 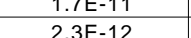 & & & & & & & \\
\hline & & & & U-238 & 1.7F-07 & 1.0E-03 & & & & & & 1.7.7-10 & & & & & & & \\
\hline 614 & Open Area & Area source & Repackaging of waste & Am-241 & $5.4 E-12$ & $1.0 \mathrm{E}-03$ & $\mathrm{NA}$ & $\mathrm{NA}$ & $\mathrm{NA}$ & None & 1 & 5.4E-15 & 330 & NE & $1.3 \mathrm{E}-08$ & 282 & SW & 1.5E-08 & 5 \\
\hline & & & liquid scintillation cocktail & $\frac{C-14}{-51}$ & $\frac{1.7 E=-05}{0.15-10}$ & $\begin{array}{l}1.0 \mathrm{OE}-03 \\
10.03\end{array}$ & & & & & & $1.7 \mathrm{E}-08$ & & & & & & & \\
\hline & & & & Cs-137 & $5.0 E-13$ & $1.0 \mathrm{E}-03$ & & & & & & 5 & & & & & & & \\
\hline & & & & $\frac{H-3}{P-32}$ & $\begin{array}{l}6.0 E=-05 \\
44.6-08\end{array}$ & $\begin{array}{l}1.00-03 \\
1.0 E-03\end{array}$ & & & & & & $\begin{array}{l}6.0 E-08 \\
46 E-11\end{array}$ & & & & & & & \\
\hline & & & & Pu-239 & $2.1 E-12$ & $1.0 E-03$ & & & & & & $2.1 E-15$ & & & & & & & \\
\hline & & & & $\begin{array}{l}\text { Pu-242 } \\
\text { Bas-226 }\end{array}$ & $\begin{array}{l}1.8 E-09 \\
911-13\end{array}$ & $\begin{array}{l}1.0 \mathrm{OE}-03 \\
100-03\end{array}$ & & & & & & 1.8-8-12 & & & & & & & \\
\hline & & & & 505 & $1.8 E-07$ & $1.0 \mathrm{EE}-03$ & & & & & & $1.8 \mathrm{E}-10$ & & & & & & & \\
\hline & & & & $\begin{array}{ll}\text { Sr-90 } \\
\text { Th-228 }\end{array}$ & $\begin{array}{l}4.6 E-12 \\
910-13\end{array}$ & $\begin{array}{l}1.0 \mathrm{OE}-03 \\
100-03\end{array}$ & & & & & & $\begin{array}{l}4.6 \mathrm{E}-15 \\
91 \mathrm{E}-16\end{array}$ & & & & & & & \\
\hline & & & & U-234 & $3.1 \mathrm{E}-14$ & $1.0 E-03$ & & & & & & 3.1E-17 & & & & & & & \\
\hline & & & & $\begin{array}{l}-\mathrm{U}-253 \\
\mathrm{U}-238\end{array}$ & $\begin{array}{l}4.2 E-15 \\
3.3 E-13 \\
\end{array}$ & $\begin{array}{l}1.00-03 \\
1.0 E-03\end{array}$ & & & & & & $\begin{array}{l}4.2 E-18 \\
3.3 E-16\end{array}$ & & & & & & & 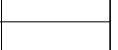 \\
\hline The South & ast Quac & le L & vated levels of Pu-239 in the surface & soil and air (presum & ably from resuspensio & on). The sou & ce of the Pu-23! & was past was & anagement & peratations. & & & & & & & & & \\
\hline Southeast & Quadrant & Area Source & Resuspension & Pu-239 & NA & ${ }_{\mathrm{NA}}$ & $\mathrm{NA}$ & NA & $\mathrm{NA}$ & None & 1 & NA & 0 & NA & $4.5 \mathrm{E}-04$ & $N A$ & $N A$ & $\mathrm{NA}$ & 6 \\
\hline STE 3000 & 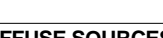 & & & & & & & & & & & & & & & & & & \\
\hline & 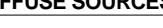 & & & & & & & & & & & & & & & & & & \\
\hline Diffuse so & rees consist of re & uspension of depleted uranium at & nd waste handling. & & & & & & & & & & & & & & & & \\
\hline Site 300 & All & Area Source & Soil resuspension & U-238 & $\mathrm{NA}$ & NA & $\mathrm{NA}$ & NA & NA & None & 1 & NA & NA & NA & $3.7 \mathrm{E}-03$ & NA & NA & NA & 6 \\
\hline & & & & 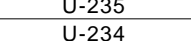 & $\frac{N A}{N A}$ & $\frac{N A}{N A}$ & & & & & & $\frac{\mathrm{NA}}{\mathrm{NA}}$ & & & & & & & \\
\hline
\end{tabular}


Attachment 1 - 2000 LLNL NESHAPs Annual Report Spreadsheet

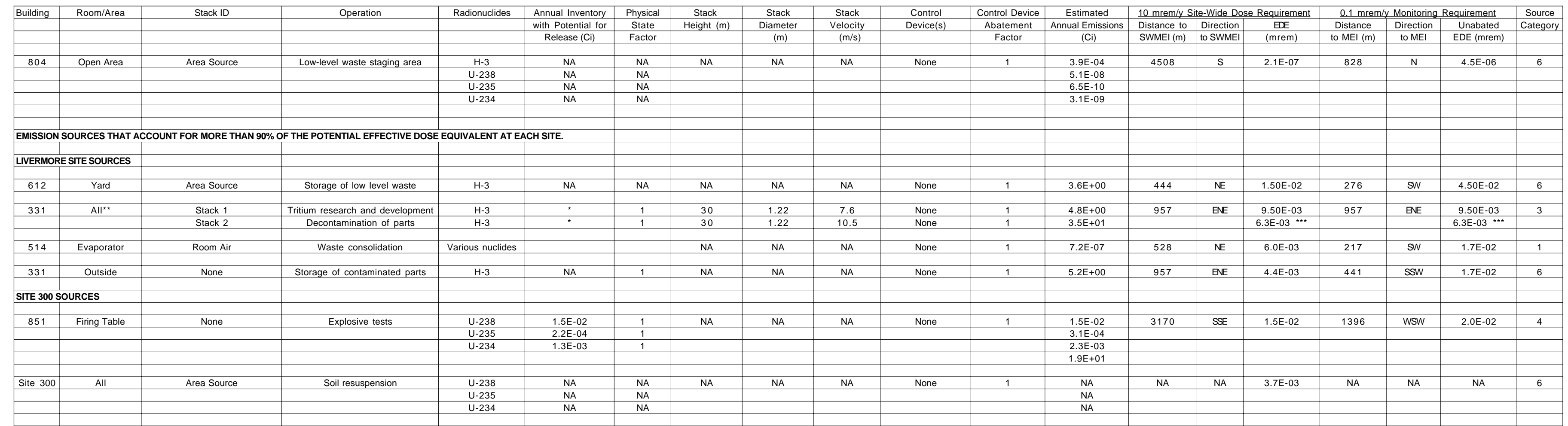


LLNL NESHAPs Report 2000

\section{Attachment 2. Brief Survey of the NEWTRIT Model}

A simple tritium model, NEWTRIT, has been developed to account for ingestion dose from OBT and for doses from releases of HT (Peterson, S-R. and P.A. Davis, 2001, Tritium Doses from Chronic Atmospheric Releases: A New Approach Proposed for Regulatory Compliance". Accepted upon revision by Health Physics. UCRL-JC-141535).

NEWTRIT exists in two forms, NEWTRIT_HTO and NEWTRIT_HT. Spreadsheet versions of both exist that calculate dose to an individual using an air concentration predicted by a dispersion model. In addition, NEWTRIT has been programmed into CAP88-PC so that it can predict doses to individuals at many locations simultaneously and to populations. NEWTRIT uses the latest dose coefficients for HT, HTO and OBT of the International Commission on Radiological Protection (International Commission on Radiological Protection, 1995, Age dependent doses to members of the public from intake of radionuclides, Part 4, Inhalation Dose Coefficients. Oxford: Pergamon Press; ICRP Publication 71; Ann. ICRP 25[3\&4]); International Commission on Radiological Protection, 1996, Age dependent doses to members of the public from intake of radionuclides, Part 5, Compilation of Ingestion and Inhalation Dose Coefficients from Parts 1-4. Oxford: Pergamon Press; ICRP Publication 72; Ann. ICRP 26(1)).

Because of assumptions about reductions in concentrations of tritium in the food chain, the dose to the individual calculated by NEWTRIT is actually somewhat reduced compared to the dose calculated by CAP88-PC, even compared to CAP88PC doses calculated ignoring any contribution by HT. NEWTRIT's total tritium dose to an individual from a release of HTO, given assumptions used at LLNL, is $75 \%$ that of CAP88-PC's tritium model. About 31\% of NEWTRIT's dose to the individual from a release of HTO is contributed by OBT. For dose to population from a release of HTO, the predictions of NEWTRIT and the CAP88-PC tritium model are very similar. This is due to the reduced importance of food and the increased relative importance of inhalation and drinking water to population dose due to assumptions in CAP88-PC. The contribution of OBT to population dose is much less for the population than for the individual - only about $10 \%$.

The relative contribution of OBT and HTO to dose from HT releases, as calculated by NEWTRIT, are similar to the doses from the HTO releases just described. NEWTRIT's dose to an individual from a release of HT, given assumptions used at LLNL, are 7.0\% those of CAP88-PC's HTO model. About 33\% of NEWTRIT's dose to the individual from a release of HT is contributed by OBT. The relative importance of the doses predicted by the two models for population is very similar (NEWTRIT's dose is $7.2 \%$ that of CAP88-PC), but the contribution of OBT to this dose is much smaller than for the individual (14\%). 
LLNL NESHAPs Report 2000

The amount NEWTRIT reduces dose to the individual or the population relative to CAP88-PC is dependent upon the relative release rates of HT and HTO from LLNL. Although NEWTRIT's dose predictions are lower than those of CAP88-PC, they are still conservative.

The EPA has expressed interest in NEWTRIT, and LLNL is hopeful that this interest will develop into acceptance of NEWTRIT or a similar approach to modeling releases of HT and HTO for regulatory compliance. 


\section{Attachment 3. Surrogate Radionuclides List}

The need for selection of a surrogate isotope occurs when an isotope used in operations (isotope of interest) is not contained in the limited nuclide library in the NESHAPs dose compliance model CAP88-PC. The selection of a suitable surrogate is based upon several criteria. If possible, a surrogate isotope is chosen from the CAP88-PC radionuclide library that has a metabolically similar behavior to the isotope of interest. Following an acute inhalation exposure, the metabolically similar surrogate would concentrate in specific organs and tissues as the isotope of interest. In most cases the surrogate selected possesses similar modes of decay and decay energies of the radiation type of the isotope of interest. Thus, the surrogate models the behavior of the isotope with similar relative biological effect due to deposition energy.

According to present knowledge, the daughter nuclides produced following physical decay are assumed to remain organ site specific and follow the translocation pathway of the parent. Therefore, when a surrogate of similar metabolic behavior is not available or has a greatly dissimilar half-life, the surrogate chosen is a daughter nuclide of the isotope of interest that will remain organ site specific and follow the translocation pathway of the parent.

Once a surrogate has been selected, the equivalent source term is adjusted by the product of the initial inventory of the isotope of interest and the ratio of the effective dose equivalent of the surrogate to that of the isotope of interest. For determining the dose ratio, the primary exposure pathway is assumed to be that of inhalation and inhalation dose conversion factors (International Commission on Radiological Protection Publication No. 71, "Age-dependent Doses to Members of the Public from Intake of Radionuclides: Part 4 Inhalation Dose Coefficients," Elsevier Science Ltd., 1996) are used for determination of the effective dose equivalents.

In addition, isotopic analysis of mixtures of radionuclides are not always available, and radionuclide usage inventories are stated as "gross alpha," "gross beta," "gross gamma," or "mixed fission products" (MFP). In these cases, ${ }^{239} \mathrm{Pu}$ is used as the surrogate for gross alpha, ${ }^{137} \mathrm{Cs}$ is used as the surrogate for gross gamma, and ${ }^{90} \mathrm{Sr}$ is used as the surrogate for gross beta and mixed fission products to provide conservative dose estimates.

Table 3-1 provides a list a radionuclides not in the CAP88-PC library and their respective surrogates. 
LLNL NESHAPs Report 2000

Table 3-1. List of surrogate radionuclides.

\begin{tabular}{|c|c|c|c|c|c|c|c|c|c|}
\hline Isotope & $\begin{array}{c}\text { Half- } \\
\text { Life }\end{array}$ & $\begin{array}{l}\text { Lung } \\
\text { Class }^{a}\end{array}$ & $\begin{array}{c}\text { ALI (inh) } \\
\mu \mathrm{Ci}\end{array}$ & $\begin{array}{c}\text { DAC (inh) } \\
\mu \mathrm{Ci} / \mathrm{m}^{3}\end{array}$ & Surrogate & $\begin{array}{c}\text { Half- } \\
\text { e Life }\end{array}$ & $\begin{array}{c}\text { Lung } \\
\text { Class }^{a}\end{array}$ & $\begin{array}{c}\text { ALI (inh) } \\
\qquad \mathrm{MCi}\end{array}$ & $\begin{array}{c}\text { DAC (inh) } \\
\mu \mathrm{Ci} / \mathrm{m}^{3}\end{array}$ \\
\hline Ca-108m & n $127 y$ & Y & $2.0 \times 10^{1}$ & $1.0 \times 10^{-8}$ & Co-60 & $5.271 \mathrm{y}$ & Y & $3.0 \times 10^{1}$ & $1.0 \times 10^{-8}$ \\
\hline Bi-207 & $38 \mathrm{~d}$ & W & $4.0 \times 10^{2}$ & $1.0 \times 10^{-7}$ & Bi-214 & $19.9 \mathrm{~min}$ & W & $9.0 \times 10^{2}$ & $4.0 \times 10^{-7}$ \\
\hline Ca-45 & $163 \mathrm{~d}$ & W & $8.0 \times 10^{2}$ & $4.0 \times 10^{-7}$ & Sr-90 & $29.12 \mathrm{y}$ & $\mathrm{D}$ & $2.0 \times 10^{1}$ & $8.0 \times 10^{-9}$ \\
\hline Cd-109 & $464 \mathrm{~d}$ & $\mathrm{Y}$ & $1.0 \times 10^{2}$ & $5.0 \times 10^{-}-8$ & Co-60 & $5.271 \mathrm{y}$ & Y & $3.0 \times 10^{1}$ & $1.0 \times 10^{-8}$ \\
\hline Cf-249 & $350.6 \mathrm{y}$ & $\mathrm{Y}$ & $1.0 \times 10^{-2}$ & $4.0 \times 10^{-12}$ & $\mathrm{Cm}-245$ & $8500 \mathrm{y}$ & W & $6.0 \times 10^{-3}$ & $3.0 \times 10^{-12}$ \\
\hline Cf-250 & $13.1 \mathrm{y}$ & W & $9.0 \times 10^{-3}$ & $4.0 \times 10^{-12}$ & Am-241 & $432.2 \mathrm{y}$ & W & $6.0 \times 10^{-3}$ & $3.0 \times 10^{-12}$ \\
\hline $\mathrm{Cl}-36$ & $3.01 \times 10^{5} \mathrm{y}$ & $y$ W & $2.0 \times 10^{2}$ & $1.0 \times 10^{-7}$ & Cs-137 & $30 y$ & $\mathrm{D}$ & $2.0 \times 10^{2}$ & $6.0 \times 10^{-8}$ \\
\hline Es-254 & $275.7 \mathrm{~d}$ & $\mathrm{~W}$ & $7.0 \times 10^{-2}$ & $3.0 \times 10^{-11}$ & Pu-239 & $24065 \mathrm{y}$ & Y & $2.0 \times 10^{-2}$ & $7.0 \times 10^{-12}$ \\
\hline Eu-149 & $93.1 \mathrm{~d}$ & W & $3.0 \times 10^{3}$ & $1.0 \times 10^{-6}$ & Pm-151 & $28.4 \mathrm{hr}$ & $\mathrm{Y}$ & $3.0 \times 10^{3}$ & $1.0 \times 10^{-6}$ \\
\hline Gd-148 & $93 \mathrm{y}$ & $\mathrm{D}$ & $8.0 \times 10^{-3}$ & $3.0 \times 10^{-12}$ & La-140 & $40.272 \mathrm{~h}$ & W & $1.0 \times 10^{3}$ & $5.0 \times 10^{-7}$ \\
\hline Os-185 & $94 \mathrm{~d}$ & $\mathrm{D}$ & $5.0 \times 10^{2}$ & $2.0 \times 10^{-7}$ & Mo-99 & $66 \mathrm{~h}$ & Y & $1.0 \times 10^{3}$ & $6.0 \times 10^{-7}$ \\
\hline P-33 & $25.4 \mathrm{~d}$ & W & $3.0 \times 10^{3}$ & $1.0 \times 10^{-6}$ & P-32 & $14.29 \mathrm{~d}$ & $\mathrm{D}$ & $9.0 \times 10^{2}$ & $4.0 \times 10^{-7}$ \\
\hline $\operatorname{Re}-184$ & $38 \mathrm{~d}$ & W & $1.0 \times 10^{3}$ & $6.0 \times 10^{-7}$ & Mo-99 & $66 \mathrm{~h}$ & $\mathrm{Y}$ & $1.0 \times 10^{3}$ & $6.0 \times 10^{-7}$ \\
\hline Se-75 & $119.8 \mathrm{~d}$ & W & $6.0 \times 10^{2}$ & $3.0 \times 10^{-7}$ & As-76 & $26.32 \mathrm{~h}$ & W & $1.0 \times 10^{3}$ & $6.0 \times 10^{-7}$ \\
\hline Sr-85 & $64.8 \mathrm{~d}$ & $\mathrm{D}$ & $3.0 \times 10^{3}$ & $1.0 \times 10^{-6}$ & Sr-90 & $29.12 \mathrm{y}$ & $\mathrm{D}$ & $2.0 \times 10^{1}$ & $8.0 \times 10^{-9}$ \\
\hline Тa-182 & $115 d$ & $\mathrm{Y}$ & $1.0 \times 10^{2}$ & $6.0 \times 10^{-8}$ & Hf-181 & $42.4 \mathrm{~d}$ & $\mathrm{~W}$ & $4.0 \times 10^{2}$ & $2.0 \times 10^{-7}$ \\
\hline Tb-157 & $110 y$ & W & $3.0 \times 10^{2}$ & $1.0 \times 10^{-7}$ & La-140 & $40.272 \mathrm{~h}$ & W & $1.0 \times 10^{3}$ & $5.0 \times 10^{-7}$ \\
\hline Tb-158 & $180 y$ & $\mathrm{~W}$ & $2.0 \times 10^{1}$ & $8.0 \times 10^{-9}$ & La-140 & $40.272 \mathrm{~h}$ & W & $1.0 \times 10^{3}$ & $5.0 \times 10^{-7}$ \\
\hline Tl-204 & $3.78 \mathrm{y}$ & $\mathrm{D}$ & $2.0 \times 10^{3}$ & $9.0 \times 10^{-7}$ & $\mathrm{~Pb}-214$ & $26.8 \mathrm{~min}$ & $\mathrm{D}$ & $8.0 \times 10^{2}$ & $3.0 \times 10^{-7}$ \\
\hline Tm-168 & $93.1 \mathrm{~d}$ & W & $2.0 \times 10^{3}$ & $8.0 \times 10^{-7}$ & La-140 & $40.272 \mathrm{~h}$ & W & $1.0 \times 10^{3}$ & $5.0 \times 10^{-7}$ \\
\hline Tm-171 & $1.92 \mathrm{y}$ & Y & $3.0 \times 10^{2}$ & $1.0 \times 10^{-7}$ & La-140 & $40.272 \mathrm{~h}$ & W & $1.0 \times 10^{3}$ & $5.0 \times 10^{-7}$ \\
\hline Y-88 & $106.64 \mathrm{~d}$ & $\mathrm{Y}$ & $2.0 \times 10^{2}$ & $1.0 \times 10^{-7}$ & Y-90 & $64 \mathrm{~h}$ & $\mathrm{Y}$ & $6.0 \times 10^{2}$ & $3.0 \times 10^{-7}$ \\
\hline Am-244 & $10.1 \mathrm{~h}$ & W & $2.0 \times 10^{2}$ & $8.0 \times 10^{-}-8$ & $\mathrm{Cm}-244$ & $18.11 \mathrm{y}$ & W & $1.0 \times 10^{-2}$ & $5.0 \times 10^{-12}$ \\
\hline Au-195 & $183 d$ & $\mathrm{Y}$ & $4.0 \times 10^{2}$ & $2.0 \times 10^{-7}$ & Вa-133 & $10.74 \mathrm{y}$ & $\mathrm{D}$ & $7.0 \times 10^{2}$ & $3.0 \times 10^{-7}$ \\
\hline Co-56 & $78.76 \mathrm{~d}$ & Y & $2.0 \times 10^{2}$ & $8.0 \times 10^{-8}$ & Co-60 & $5.271 \mathrm{y}$ & $\mathrm{Y}$ & $3.0 \times 10^{1}$ & $1.0 \times 10-8$ \\
\hline Gd-146 & $48.3 \mathrm{~d}$ & $\mathrm{~W}$ & $3.0 \times 10^{2}$ & $1.0 \times 10^{-7}$ & \multicolumn{2}{|c|}{ Sm-147 $1.06 \times 10^{11} \mathrm{y}$} & $\mathrm{W}$ & $4.0 \times 10^{-2}$ & $2.0 \times 10^{-11}$ \\
\hline Kr-85 & $10.72 \mathrm{y}$ & Gas & See Note & $1.0 \times 10^{-4}$ & & & & & \\
\hline Rh-102 & $2.9 \mathrm{y}$ & Y & $6.0 \times 10^{1}$ & $2.0 \times 10^{-8}$ & Rh-106m & $29.9 \mathrm{~s}$ & Y & $4.0 \times 10^{4}$ & $1.0 \times 10^{-5}$ \\
\hline U-239 & $23.54 \mathrm{~min}$ & $Y$ & $2.0 \times 10^{5}$ & $6.0 \times 10^{-5}$ & U-240 & $14.1 \mathrm{~h}$ & Y & $2.0 \times 10^{3}$ & $1.0 \times 10^{-6}$ \\
\hline $\mathrm{Zr}-90$ & $809 \mathrm{~ms}$ & W & $\mathrm{N} / \mathrm{A}$ & $\mathrm{N} / \mathrm{A}$ & $Y-90$ & $64 \mathrm{~h}$ & Y & $6.0 \times 10^{2}$ & $3.0 \times 10^{-7}$ \\
\hline Po-209 b & $102 y$ & $\mathrm{~N} / \mathrm{A}$ & $\mathrm{N} / \mathrm{A}$ & $\mathrm{N} / \mathrm{A}$ & Pu-239 & $24065 \mathrm{y}$ & Y & $2.0 \times 10^{-2}$ & $7.0 \times 10^{-12}$ \\
\hline
\end{tabular}

Note: The DAC for $\mathrm{Kr}-85$ also has been relaxed considerably since its beta emission only irradiates the skin. The DAC is based on limitation of non-stochastic effects in the skin; the MPC was derived assuming that the beta particles of energy greater than $0.1 \mathrm{MeV}$ contributed to the whole body dose.

a $\mathrm{D}=$ days, $\mathrm{W}=$ weeks, $\mathrm{Y}=$ years.

b No ALI or DAC information available. Pu-239 used to provide a conservative alpha-emitter dose.

Source: Limiting Values of Radionuclide Intake and Air Concentration and Dose Conversion Factors for Inhalation, Submersion and Ingestion, Federal Guidance Report No. 11, EPA-520/1-88020, U.S. Environmental Protection Agency, 1988. 